\title{
JGZ-richtlijn Psychosociale problemen
}

Colofon

Autorisatie: 19 september 2016 door de AJN, V\&VN vakgroep jeugd en NVDA en randvoorwaardelijk door Actiz en GGD Nederland/GHOR

Publicatiedatum: 1 december 2016

Projectnummer: 060.09295

Richtlijnontwikkelaar: TNO

Deze richtlijn is gefinancierd door ZonMw 


\section{Inhoudsopgave}

JGZ-richtlijn Psychosociale problemen

$\underline{\text { Inleiding }}$

Taken van de Jeugdgezondheidszorg

Aandacht voor gezond opgroeien en opvoeden

Voorkomen van risico's en psychosociale problemen

$\underline{\text { Instrumenten en klinische blik }}$

Definitie en prevalentie van psychosociale problemen

$\underline{\text { Definitie }}$

Prevalentie

$\underline{V e r s c h i l ~ i n ~ p s y c h o s o c i a l e ~ p r o b l e m e n ~ p e r ~ g e s l a c h t, ~ l e e f t i j d ~ e n ~ t y p e ~ p r o b l e e m ~}$

Mijlpalen in de sociale emotionele ontwikkeling van kinderen

Symptomen

Psychiatrische stoornissen

Gehechtheid en psychosociale problemen

Gevolgen van psychosociale problemen

$\underline{\text { Referenties }}$

Thema 1 Risico- en beschermende factoren

$\underline{\text { Inleiding }}$

Aanbevelingen

Onderbouwing

Overzicht van de risico- en beschermende factoren en sterkte van de verbanden

Het in beeld brengen van risico en beschermende factoren

5. $\quad$ Referenties

Thema 2 Vroegsignalering van psychosociale problemen

Inleiding

Aanbevelingen

Uitgangsvragen 
Onderbouwing

$\underline{\text { Vroegsignalering door de JGZ }}$

Weerstand van ouders om vragenlijsten in te vullen

Het overzicht van signaleringsinstrumenten

Diagnostische instrumenten

$\underline{\text { Referenties }}$

Thema 3 Advisering en interventies bij psychosociale problemen

Inleiding

Aanbevelingen

Uitgangsvragen

Onderbouwing

Algemeen handelen bij psychosociale problemen

4.2 Adviezen om de psychosociale ontwikkeling van het kind te stimuleren

4.3 Effectieve interventies bij psychosociale problemen

5. $\quad$ Referenties

Thema 4 Samenwerking

Inleiding

Aanbevelingen

Uitgangsvraag

Onderbouwing

Samenwerken rond de signalering

4.2 Samenwerking rond de ondersteuning van gezinnen

$\underline{\text { Referenties }}$

Totstandkoming richtlijn

Werkwijze

Werkgroep

Klankbordgroep

Cliëntenparticipatie 
Verantwoording

Zoekstrategie

Evidentietabellen en niveau van bewijsvoering

Overwegingen

Knelpuntenanalyse 


\section{Inleiding}

De herziene JGZ-richtlijn 'Psychosociale problemen' beoogt JGZ-professionals een up-to-date en (wetenschappelijk en praktijk-) onderbouwd fundament te bieden voor het signaleren, bespreekbaar maken, registreren, handelen en samenwerken met betrekking tot psychosociale problemen bij het kind.

De oude JGZ-richtlijn uit 2008 (Postma) 'Vroegsignalering van psychosociale problemen' is beperkt tot vroegsignalering van psychosociale problemen. In deze oude richtlijn werd een overzicht gegeven van de risico- en beschermende factoren, waarbij het balansmodel van Bakker $(1997,1998)$ als basis wordt gebruikt. Ook wordt een overzicht gegeven van veelbelovende vroegsignaleringsinstrumenten. In 2008 was er in Nederland nog weinig onderzoek gedaan naar deze instrumenten, waardoor de kennis over de validiteit destijds beperkt was.

In de herziene richtlijn is er niet alleen aandacht voor vroegsignalering, maar ook voor interventies en samenwerken in de keten. In de herziene richtlijn wordt ingegaan op de definitie van psychosociale problemen. De belangrijkste risico- en beschermende factoren voor psychosociale problematiek zijn in kaart gebracht met behulp van een systematische literatuursearch. Verder zijn per leeftijdsgroep enkele korte valide instrumenten aanbevolen die ingezet kunnen worden tijdens een 'standaard' contactmoment om psychosociale problemen te signaleren. Ook geeft de richtlijn aan welke adviezen en interventies ingezet kunnen worden als psychosociale problematiek vermoed wordt. Ten slotte is beschreven hoe de samenwerking met ouders en andere professionals verbeterd zou kunnen worden.

Doel

De richtlijn is bedoeld als leidraad voor het handelen van professionals in de jeugdgezondheidszorg (JGZ) in hun contacten met individuele kinderen en/of hun ouders/verzorgers, daar waar het gaat om primaire, secundaire en tertiaire preventie van psychosociale problemen bij kinderen.

De definitie van richtlijnen luidt:

Een richtlijn is een document met aanbevelingen, gericht op het verbeteren van de kwaliteit van zorg, berustend op systematische samenvattingen van wetenschappelijk onderzoek en afwegingen van de voor- en nadelen van de verschillende zorgopties, aangevuld met expertise en ervaringen van zorgprofessionals en zorggebruikers. (Regieraad Kwaliteit van Zorg, 2012).

De richtlijn is bedoeld voor artsen en verpleegkundig(en)(specialist) werkzaam in de JGZ, in deze richtlijn de JGZ-professionals. Daar waar jeugdarts staat kan ook verpleegkundig specialist gelezen worden. Daar waar ouders staat, kan ook verzorgers of naasten worden gelezen.

\section{Taken van de Jeugdgezondheidszorg}

Gestart wordt met een korte schets van de taken van de jeugdgezondheidszorg en welke plaats het opsporen van psychosociale problemen heeft binnen het takenpakket.

\section{Aandacht voor gezond opgroeien en opvoeden}

Sinds 1 januari 2015 is het Basispakket JGZ ingevoerd; dit Basispakket stelt vaccinaties, screeningen, monitoring en signalering actief ter beschikking. Hoewel dergelijke activiteiten er voor alle jeugdigen moeten zijn, kan de uitvoering ervan per kind of jongere variëren. Dit is 
afhankelijk van de specifieke behoefte en situatie van kind, gezin en omgeving. Waar nodig wordt voorlichting, advies, begeleiding en toeleiding naar zorg gegeven. Met uitleg en advies (ontwikkelingsgerichte informatie) kan de JGZ zorgen wegnemen en de situatie normaliseren, en zo bijdragen aan het versterken van eigen kracht en onnodige medicalisering helpen tegengaan. Hiermee wordt voorkomen dat alledaagse problemen ten onrechte bij zware, specialistische zorg terechtkomen, maar ook dat problemen ten onrechte niet behandeld worden, waardoor in een later stadium juist een extra beroep op gespecialiseerde zorg nodig zou zijn.

\section{Voorkomen van risico's en psychosociale problemen}

Een onderdeel van de taken van de JGZ is het volgen van de (psychosociale) ontwikkeling van kinderen en jeugdigen tussen 0 en 18 jaar. In de JGZ staat de lichamelijke, psychosociale en cognitieve ontwikkeling in samenhang met de omgeving (gezin, onderwijs en vrije tijd) centraal. Hierbij past een brede integrale benadering van kinderen en jeugdigen, vanuit een biopsychosociaal perspectief (Engel, 1980). Volgens deze benadering zijn zowel biologische (denk aan aanleg en erfelijkheid), psychologische (persoonlijkheid) als sociale aspecten (omgeving, gezin, opvoedsituatie) van invloed op het ontstaan en beloop van problemen. Vaak zijn er meerdere factoren die hierbij een rol spelen, bovendien kunnen factoren elkaars effect versterken. Wanneer een biologisch-genetische kwetsbaarheid aanwezig is, kan onder invloed van omgevingsfactoren een preklinische of prodromale fase ontstaan. In die fase zijn er nog geen signalen waarneembaar. Als de ongunstige interactieprocessen doorgaan, kunnen de eerste symptomen of problemen ontstaan. Preventie van gevolgen van opkomende problemen is vooral van belang in de fase dat klachten, problemen, symptomen (nog) niet zijn uitgekristalliseerd tot een classificeerbare diagnose. Immers, er kan ook al sprake zijn van (beginnende) lijdensdruk dan wel een stagnerende ontwikkeling nog vóórdat er een formele diagnose gesteld kan worden. De JGZ biedt een uniek kader om deze beginnende problemen positief te beïnvloeden in een vroeg stadium.

\section{Instrumenten en klinische blik}

Instrumenten zoals vragenlijsten en protocollen kunnen een goed hulpmiddel zijn in de JGZ bij het signaleren van (psychosociale) problemen en het inzetten van vervolgacties. De JGZ-professional kan beslissingen beter onderbouwen wanneer een instrument ingezet wordt, dit is onderzocht bij de signalering van psychosociale problemen (Vogels et al., 2009; Theunissen et al., 2013). Ook de dialoog met de ouder, de observatie van het kind en de observatie van de interactie tussen kind en ouders leveren relevante informatie op. Uiteindelijk wordt zowel gekeken naar risico- als beschermende factoren. Op basis van de informatie van deze verschillende bronnen (vragenlijst, gesprek en observatie) maakt de professional samen met de ouder de balans op en volgt een advies over de benodigde stappen.

\section{Definitie en prevalentie van psychosociale problemen}

\section{Definitie}

Uitgegaan wordt van de definitie die eveneens gehanteerd wordt binnen de Lokale en Nationale Monitor Jeugdgezondheid (zie ook Zeijl et al., 2005) en een aantal proefschriften die gericht zijn op de vroegsignalering van psychosociale problemen door de JGZ (Vogels, 2009; Theunissen, 2013).

Onder psychosociale problemen worden in dit document verstaan:

- emotionele problemen (oftewel internaliserende problemen) zoals angst, teruggetrokkenheid, depressieve gevoelens, psychosomatische klachten;

- gedragsproblemen (oftewel externaliserende problemen) zoals agressief gedrag, onrustig gedrag en delinquent gedrag; 
- sociale problemen, dit zijn problemen die het kind heeft in het maken en onderhouden van het contact met anderen.

\section{Prevalentie}

De prevalentie van psychosociale problemen bij kinderen in Nederland is aanzienlijk. Uit een onderzoek onder 0-12 jarigen (Zeijl et al., 2005) is naar voren gekomen dat $11 \%$ tot $28 \%$, afhankelijk van de leeftijdsgroep, volgens de JGZ psychosociale problemen heeft. Volgens ouders van 0-12 jarigen is dat 4-6\% op basis van hun oordeel op de Child Behavior Checklist vragenlijst (Zeijl et al., 2005), of iets hoger volgens meer recentere cijfers $10 \%$ (8-12 jarigen)(Bot et al., 2011). De prevalentie van psychosociale problemen bij adolescenten (11-16 jarigen, zelf-rapportage) is $16 \%$ (Dorsselaer, et al., 2005).

De gevonden prevalenties zijn onder meer afhankelijk van de gebruikte meetmethode en definities.

\section{Verschil in psychosociale problemen per geslacht, leeftijd en type probleem} De prevalentie van psychosociale problemen verschilt tussen jongens en meisjes (per type psychosociaal probleem). In de basisschoolleeftijd rapporteren jongens vaker externaliserende problemen. Tijdens de adolescentie komen internaliserende problemen vaker voor bij meisjes (Dorsselaer 2005;van Steijn et al., 2014).

De prevalentie van psychosociale problemen (ouderrapportage) verschilt ook per type psychosociaal probleem. Van de Nederlandse basisschoolkinderen heeft $8 \%$ een externaliserend probleem en $12 \%$ een internaliserend probleem (Reijneveld et al., 2006). Bij adolescenten (13-16 jarigen) varieert de prevalentie van internaliserende problemen van $17-19 \%$, en de prevalentie van externaliserende problematiek van $14-18 \%$, afhankelijk van de leeftijdsgroep (van Stein et al., 2014).

\section{Mijlpalen in de sociale emotionele ontwikkeling van kinderen}

Een overzicht van de mijlpalen in de sociaal emotionele ontwikkeling van het kind kan ondersteuning bieden voor de JGZ-professional bij het herkennen van een afwijkende psychosociale ontwikkeling.

Tabel 1 geeft de mijlpalen weer die een kind doorloopt op het gebied van sociaal-emotionele ontwikkeling, waarbij een uitsplitsing is gemaakt naar leeftijd. Deze tabel is gebaseerd op twee handboeken op het gebied van ontwikkeling van het kind (Bernstein et al., 1997; Sroufe et al., 1996). Uiteraard dienen deze mijlpalen altijd in context te worden bezien. Bij een te vroeg geboren kind bijvoorbeeld zullen correcties voor leeftijd moeten worden gemaakt (zie Richtlijn te vroeg en SGA geboren kinderen). Zie ook het schema van NCJ ontwikkelingsaspecten en omgeving en het van Wiechen ontwikkelingsonderzoek [LINK

https://www.ncj.nl/programma-s-producten/van-wiechen-ontwikkelingsonderzoek1].

Tabel 1: Mijlpalen in de sociaal-emotionele ontwikkeling van kinderen

\begin{tabular}{|lll|}
\hline Leeftijd & Bernstein (1997) & \multicolumn{1}{c|}{$\begin{array}{c}\text { Sociaal emotionele mijlpalen } \\
\text { Sroufe (1996) }\end{array}$} \\
\hline $0-3$ maanden & $\begin{array}{l}\text { Preferentiële voorkeur voor degene die het kind verzorgt } \\
\text { (Zoals lachen op contact en pret maken bij contact) }\end{array}$ \\
\hline $7-12$ maanden & $\begin{array}{l}\text { Verschijning van emoties zoals blijdschap, woede, angst en } \\
\text { verrassing }\end{array}$ \\
& Angst voor vreemden \\
& $\begin{array}{l}\text { Angst voor scheiding van de verzorgers (uit zich in angst bij } \\
\text { separatie en blijdschap wanneer de ouder/verzorger } \\
\text { terugkomt) }\end{array}$ \\
& Sociale interactie: kinderen kunnen anticiperen op de acties \\
& van anderen en expres deze acties opzoeken. \\
\hline
\end{tabular}




\begin{tabular}{|c|c|c|}
\hline 0-24 maanden & $\begin{array}{l}\text { Het spelen richt zich op speelgoed, niet op andere } \\
\text { kinderen } \\
\text { Kinderen reageren op emotionele uitdrukkingen van } \\
\text { anderen }\end{array}$ & \\
\hline $12-36$ maanden & & $\begin{array}{l}\text { Bewustzijn van jezelf als een persoon } \\
\text { Toegenomen bewustzijn van andere als onafhankelijke } \\
\text { personen met hun eigen wensen en intenties (herkenning } \\
\text { dat eigen intenties anders kunnen zijn dan die van anderen) } \\
\text { Het begin van zelfcontrole } \\
\text { Ontstaan van nieuwe emoties (die samenhangen met } \\
\text { herkennen van zichzelf als zelfstandig persoon, zoals } \\
\text { schuldgevoel en kwetsbaarheid) }\end{array}$ \\
\hline 2-4 jaar & $\begin{array}{l}\text { Kinderen worden meer zelfstandig, en hebben niet langer } \\
\text { meer constante aandacht nodig van hun verzorgers } \\
\text { Speelgoed wordt gebruik om reacties te weeg te brengen } \\
\text { bij andere kinderen } \\
\text { Kinderen kunnen de emoties van anderen herkennen }\end{array}$ & \\
\hline 2,5-5 jaar & & $\begin{array}{l}\text { Relaties met vriendjes } \\
\text { Toenemende zelfregulatie. Ze kunnen bepaald gedrag } \\
\text { tegenhouden, en langer wachten op een beloning, en } \\
\text { frustraties meer tolereren. } \\
\text { Kinderen krijgen begrip van 'self-constancy', de perceptie } \\
\text { van een stabiel zelf dat blijft ondanks verschillende } \\
\text { gedragingen en reacties van anderen. } \\
\text { Kinderen krijgen specifieke gedachten en gevoelens (positief } \\
\text { of negatief) over zichzelf. Dit wordt ook wel zelfvertrouwen } \\
\text { genoemd. }\end{array}$ \\
\hline 4-10 jaar & $\begin{array}{l}\text { Kinderen beginnen met samenwerken, samen spelletjes } \\
\text { spelen, en het vormen van vriendschappen } \\
\text { Kinderen leren sociale regels zoals beleefdheid, } \\
\text { rolverdelingen (zoals man versus vrouw), en het } \\
\text { controleren van hun emoties }\end{array}$ & \\
\hline 5-12 jaar & & $\begin{array}{l}\text { Kinderen ontwikkelen een meer uitgebreide zelfconcept } \\
\text { (i.p.v. jezelf zien in fysieke kenmerken) } \\
\text { Het ontstaan van een sociaal zelf. Ofwel kinderen definiëren } \\
\text { zichzelf in termen van groepen waarbij ze bij horen (bijv. ik } \\
\text { ben aardig) } \\
\text { Realisatie dat succes of falen afhankelijk is van zijn/haar } \\
\text { eigen acties } \\
\text { Toenemend begrip over hoe andere mensen denken en } \\
\text { voelen. Vriendschappen worden dieper. Dit stimuleert het } \\
\text { ontwikkelen van empathie voor anderen, verdieping van } \\
\text { morele zorgen en beter begrip van morele issues. } \\
\text { Ze leren veel van broertjes en zusjes, zoals het verzorgen van } \\
\text { anderen, onderhandelen, omgaan met woede zonder het } \\
\text { beëindigen van een relatie. } \\
\text { Op school wordt geleerd om te gaan met culturele normen } \\
\text { en waarden }\end{array}$ \\
\hline 11-15 jaar & $\begin{array}{l}\text { Op sociaal en emotioneel gebied ontstaan er } \\
\text { veranderingen, zoals } \\
\text {-stemmingswisselingen } \\
\text {-Conflicten met ouders }\end{array}$ & \\
\hline Adolescentie & & $\begin{array}{l}\text { Een belangrijke taak van een adolescent is om een eigen } \\
\text { identiteit te krijgen, een nieuw niveau van verbondenheid en } \\
\text { vertrouwen met leeftijdsgenoten, een nieuwe status in de } \\
\text { familie, en meer zelfstandigheid binnen en buiten de familie. } \\
\text { Adolescenten worden bewust dat zij andere gedachten en } \\
\text { gevoelens hebben dan anderen. } \\
\text { Het vormen van een persoonlijke identiteit, waarbij een } \\
\text { coherent geheel wordt gevormd van eerdere ervaringen, } \\
\text { huidige ontwikkelingen en verwachtingen van de } \\
\text { maatschappij met betrekking tot de toekomst. }\end{array}$ \\
\hline
\end{tabular}




\section{Symptomen}

Een symptoom van een psychosociaal probleem (bijv. druk gedrag) is een enkelvoudige of specifieke gedraging die als ongewenst wordt bestempeld, maar die op zichzelf niet kan worden beschouwd als een teken van (ernstig) disfunctioneren. Er is sprake van een psychosociaal probleem wanneer een aantal aan elkaar gerelateerde symptomen voorkomen. Dit kan duiden op een ernstigere situatie dan een enkel symptoom. $\mathrm{Er}$ is geen meetlat beschikbaar die aangeeft wanneer er sprake is van een psychosociaal probleem. Wel zijn er goede vroegsignaleringsinstrumenten (bijv. Strengths and Difficulties Questionnaire) beschikbaar die een betrouwbaar en valide onderscheid kunnen maken tussen kinderen met en zonder problemen.

Bij kinderen van 14 maanden zijn de meest voorkomende symptomen (Zeijl et al., 2005):

- excessief huilen (Lange periodes aaneen huilen of schreeuwen) (zie multidisciplinaire richtlijn excessief huilen bij baby's) ;

- $\quad$ problemen met eten (weigert te eten, spuugt eten uit, verslikken, overgeven, eten van niet eetbare voorwerpen);

- $\quad$ problemen met slapen (Moeilijkheden om in slaap te vallen, of 's nachts wakker worden en dan hulp nodig hebben om in slaap te komen) (zie JGZ-richtlijn slapen) .

Internaliserend en externaliserend probleemgedrag komt bij deze leeftijdsgroep veel minder voor dan bij oudere kinderen.

Bij 2-3 jarigen zijn de meest voorkomende symptomen (Zeijl et al., 2005):

- problemen in taal en spraak ontwikkeling (zie JGZ-richtlijn spraak taal ontwikkeling);

- problemen in de sociale ontwikkeling (maakt geen oogcontact; Is "van de wereld". Heeft totaal geen aandacht voor wat er om hem/ haar heen gebeurt);

- agressief gedrag en woedeaanvallen (slaat, duwt, schopt of bijt ouders en/of andere kinderen; Is ongehoorzaam of opstandig, weigert bijvoorbeeld te doen wat er gevraagd wordt; Is destructief. Breekt dingen of maakt ze expres kapot);

- problemen met slapen (Weigeren om naar bed te gaan, moeilijkheden om in slaap te vallen, of s 'nachts wakker worden en dan hulp nodig hebben om in slaap te komen) (zie JGZ-richtlijn slapen) .

Bij kinderen van 3 jaar en ouder kunnen de symptomen van psychosociale problemen worden onderverdeeld in de categorieën emotionele, gedragsmatige of sociale problemen (zoals ook beschreven in de definitie).

Symptomen van emotionele problemen bij kinderen van 3 jaar en ouder kunnen zijn:

- $\quad$ angst (bijv. snel bang zijn);

- teruggetrokkenheid (bijv. nogal op zichzelf, neigt ertoe alleen te spelen, zenuwachtig in nieuwe situaties);

- depressieve gevoelens (bijv. veel zorgen, lijkt over dingen in te zitten, vaak ongelukkig, in de put of in tranen);

- $\quad$ psychosomatische klachten (bijv. hoofdpijn, buikpijn, misselijkheid).

Symptomen van gedragsproblemen zijn:

- agressief gedrag (bijv. met andere kinderen vechten, andere kinderen pesten, driftbuien, doorgaans niet gehoorzaam aan volwassenen, maakt ruzie met volwassenen, gemeen doen tegen volwassenen); 
- onrustig gedrag (bijv. wiebelen en friemelen, niet lang stil kunnen zitten, opdrachten niet afmaken, gemakkelijk afgeleid ,niet kunnen concentreren, denkt niet na voordat hij/zij iets doet);

- delinquent gedrag (bijv. dingen stelen thuis, op school of elders, liegen of bedriegen). Symptomen van sociale problemen zijn:

- problemen die het kind heeft in het maken en onderhouden van het contact met anderen (bijv. wordt gepest, kan beter opschieten met volwassenen dan met andere kinderen, houdt geen rekening met gevoelens van anderen) (zie JGZ-richtlijn pesten) .

\section{Psychiatrische stoornissen}

Deze paragraaf beschrijft problemen waarbij een psychiatrische stoornis vermoed kan worden, en geeft per stoornis een overzicht van de leeftijd waarop de betreffende stoornis vaak wordt vastgesteld.

Stoornissen zijn een constellatie van symptomen die onderling met elkaar samenhangen.

Psychiatrische stoornissen (zoals ADHD, autisme spectrum stoornis) houden ook in dat er sprake is van door deskundigen vastgestelde criteria waaraan een persoon moet voldoen. De DSM-5 is het handboek voor classificatie van psychiatrische stoornissen. Er is sprake van een stoornis als de symptomen (van der Ploeg 2007):

- langer dan 6 maanden aanhouden;

- $\quad$ in een cluster van nauwkeurig omschreven gedragskenmerken voorkomen zoals beschreven in de DSM-5;

- lijdensdruk (de klachten worden door kind en/of omgeving als zwaar ervaren) en/of disfunctioneren tot gevolg hebben.

Boer en Verhulst (2014) hebben een inzichtelijk overzicht gemaakt van problemen waarbij een psychiatrische stoornis vermoed kan worden (zie Tabel 2).

Tabel 2 Problemen waarbij een psychiatrische stoornis vermoed kan worden (Boer en Verhulst 2014)

\begin{tabular}{|c|c|c|}
\hline $\begin{array}{l}\text { Problemen } \\
\text { Emoties }\end{array}$ & Meest waarschijnlijk & Ook denken aan \\
\hline Omschreven angst & Angststoornis & $\begin{array}{l}\text { Autismespectrumstoornis } \\
\text { Dwangstoornis } \\
\text { Ziekteangststoornis } \\
\text { Eetstoornis } \\
\text { Psychose } \\
\end{array}$ \\
\hline Piekeren & Gegeneraliseerde angststoornis & $\begin{array}{l}\text { Dwangstoornis } \\
\text { Separatieangststoornis } \\
\text { Ziekteangststoornis } \\
\text { Depressie } \\
\end{array}$ \\
\hline Nerveus, gespannen & Gegeneraliseerde angststoornis & $\begin{array}{l}\text { Tics } \\
\text { ADHD }\end{array}$ \\
\hline Somberheid & Depressie & $\begin{array}{l}\text { ADHD } \\
\text { Gedragsstoornis }\end{array}$ \\
\hline Zelfbewuste emoties (schaamte) & Sociale fobie & $\begin{array}{l}\text { Tics } \\
\text { ADHD }\end{array}$ \\
\hline \multicolumn{3}{|l|}{ Relationele emoties } \\
\hline $\begin{array}{l}\text {-schuldgevoel } \\
\text {-niet geliefd } \\
\text {-jaloezie } \\
\text {-achterdocht }\end{array}$ & $\begin{array}{l}\text { Depressie } \\
\text { Depressie } \\
\text { Depressie } \\
\text { Psychose }\end{array}$ & $\begin{array}{l}\text { PTSS } \\
\text { Borderline-persoonlijkheidsstoornis } \\
\text { Gedragsstoornis }\end{array}$ \\
\hline
\end{tabular}




\begin{tabular}{|c|c|c|}
\hline & & Hechtingsstoornis \\
\hline Emotieregulatie & Autismespectrumstoornis & $\begin{array}{l}\text { ADHD } \\
\text { Depressie } \\
\text { Gedragsstoornis } \\
\text { Disruptieve stemmingsdisregulatiestoornis } \\
\text { Borderline-persoonlijkheidsstoornis } \\
\text { En vele anderen }\end{array}$ \\
\hline Ontbrekende emoties & Normoverschrijdend gedragsstoornis & Autismespectrumstoornis \\
\hline \multicolumn{3}{|l|}{ Gedrag } \\
\hline $\begin{array}{l}\text { Activiteitsniveau } \\
\text {-hoog }\end{array}$ & ADHD & $\begin{array}{l}\text { Angststoornis } \\
\text { Slaapstoornis } \\
\text { Depressie (geagiteerd) } \\
\text { Bipolaire stoornis (manisch) } \\
\text { Psychose }\end{array}$ \\
\hline -laag & Depressie (geremd) & Slaapstoornis \\
\hline $\begin{array}{l}\text { Vorm van activiteit } \\
\text {-Onhandig } \\
\text {-zenuwtrekken }\end{array}$ & $\begin{array}{l}\text { ADHD } \\
\text { Ticstoornis }\end{array}$ & Autismespectrumstoornis \\
\hline Beheersing (impulsief) & ADHD & Gedragsstoornis \\
\hline $\begin{array}{l}\text { Opvallend gedrag } \\
\text {-Herhaalde handelingen } \\
\text {-vreemd gedrag }\end{array}$ & $\begin{array}{l}\text { Dwangstoornis } \\
\text { Psychose }\end{array}$ & $\begin{array}{l}\text { Autismespectrumstoornis } \\
\text { Dwanghandelingen } \\
\text { Complexe tics } \\
\text { Genderdysforie }\end{array}$ \\
\hline Ongehoorzaam, dwars & $\begin{array}{l}\text { Oppositioneel-opstandige } \\
\text { gedragsstoornis }\end{array}$ & $\begin{array}{l}\text { Angststoornis } \\
\text { Autismespectrumstoornis }\end{array}$ \\
\hline Normoverschrijdend & Normoverschrijdend gedragsstoornis & $\begin{array}{l}\text { Ticstoornis (vloeken) } \\
\text { Leerstoornis (spijbelen) } \\
\text { Autismespectrumstoornis (spijbelen) }\end{array}$ \\
\hline Middelengebruik & Middelenmisbruik & $\begin{array}{l}\text { Als zelfmedicatie } \\
\text {-PTSS } \\
\text {-Sociale-angststoornis } \\
\text {-depressie } \\
\text {-psychose }\end{array}$ \\
\hline Agressief & Gedragsstoornis & $\begin{array}{l}\text { Vanuit paniek } \\
\text {-Autismespectrumstoornis } \\
\text { Als re-enactment } \\
\text {-PTSS }\end{array}$ \\
\hline \multicolumn{3}{|l|}{ Zelfbeschadigend } \\
\hline $\begin{array}{l}\text {-Ongelukken } \\
\text {-Vernielen }\end{array}$ & $\begin{array}{l}\text { ADHD } \\
\text { Depressie }\end{array}$ & Hechtingsstoornis \\
\hline -Verwonden & Bipolaire stoornis & $\begin{array}{l}\text { ADHD } \\
\text { Gedragsstoornis }\end{array}$ \\
\hline -Zelfdoding & Depressie & $\begin{array}{l}\text { Gedragsstoornis } \\
\text { Bipolaire stoornis }\end{array}$ \\
\hline \multicolumn{3}{|l|}{ Denken } \\
\hline $\begin{array}{l}\text { Vorm } \\
\text {-afgeleid }\end{array}$ & ADHD & $\begin{array}{l}\text { Angststoornissen } \\
\text { PTSS } \\
\text { Autismespectrumstoornis } \\
\text { Dwangstoornis } \\
\text { Depressie } \\
\text { Bipolaire stoornis (manische fase) }\end{array}$ \\
\hline -Verward & Psychose (jongere) & $\begin{array}{l}\text { Autismespectrumstoornis (Multiple Complex } \\
\text { Developmental Disorder, McDD) (kind) }\end{array}$ \\
\hline Inhoud (intrusief) & Dwangstoornis & Psychose \\
\hline \multicolumn{3}{|l|}{ Waarneming } \\
\hline Hallucinatie en helder bewustzijn & Psychose & Normaal (bij peuter/kleuter) \\
\hline
\end{tabular}




\begin{tabular}{|lll|}
\hline & & $\begin{array}{l}\text { Recent middelengebruik } \\
\text { MCDD }\end{array}$ \\
\hline Hallucinatie en gedaald bewustzijn & Delier & Recent middelengebruik \\
\hline Contact & & $\begin{array}{l}\text { Hechtingsstoornis } \\
\text { Depressie }\end{array}$ \\
\hline Mate van (weinig) & Autismespectrumstoornis & \\
\hline Vorm & & Autismespectrumstoornis \\
-terughouden & Sociale fobie & Gedragsstoornis \\
-te weinig terughoudend & Hechtingsstoornis (OSBS) & Angststoornis \\
\hline Kwaliteit & Autismespectrumstoornis & Depressie \\
\hline Lichamelijke klachten & Somatische symptomen stoornis & Eetstoornis \\
& & PTSS \\
\hline Slaapstoornis & & Angststoornis \\
\hline Ontwikkeling & PTSS & Aanpassingsstoornis \\
\hline Te jong & Autismespectrumstoornis & Depressie \\
\hline Ouwelijk & Autismespectrumstoornis & PTSS \\
\hline
\end{tabular}

De bovenstaande tabel houdt geen rekening met de leeftijd waarop een stoornis voorkomt. De leeftijd waarop een psychiatrische stoornis wordt vastgesteld is afhankelijk van de stoornis (Ormel et al., 2015). Figuur 2 toont de cumulatieve prevalentie tot het $18^{\mathrm{e}}$ levensjaar (ooit een psychiatrische stoornis gehad) van elke stoornis per leeftijdsjaar.

1) ADHD wordt vaak vastgesteld op jonge leeftijd en de prevalentie neemt snel toe in de leeftijd van 0-6 jaar. Na de leeftijd van 6 jaar ontstaan bijna geen nieuwe gevallen (zie JGZ-richtlijn ADHD) .

2) Fobieën beginnen meestal voor de leeftijd van 8 jaar. Er ontstaan bijna geen nieuwe gevallen na de leeftijd van 14 jaar (zie JGZ-richtlijn angst) en JGZ-richtlijn depressie .

3) Scheidingsangst begint op jonge leeftijd, maar nieuwe gevallen kunnen ontstaan tot de leeftijd van 17 jaar (zie JGZ-richtlijn angst) .

4) Gedragsstoornissen beginnen rond het tijdstip dat een kind naar school gaat, en het voorkomen neemt gestaag toe tot de leeftijd van 14-15 jaar (zie jeugdzorg richtlijn ernstige gedragsstoornissen) .

5) Andere angststoornissen (gegeneraliseerde angst stoornissen, obsessief-compulsief stoornis, paniek stoornis) en stemmingsstoornissen komen niet vaak voor tot de leeftijd van 11 jaar, daarna neemt de cumulatieve prevalentie geleidelijk toe (zie JGZ-richtlijn angst) .

6) Drugs en alcohol verslaving begint vaak pas vanaf 14 jaar en neemt dan sterk toe. 

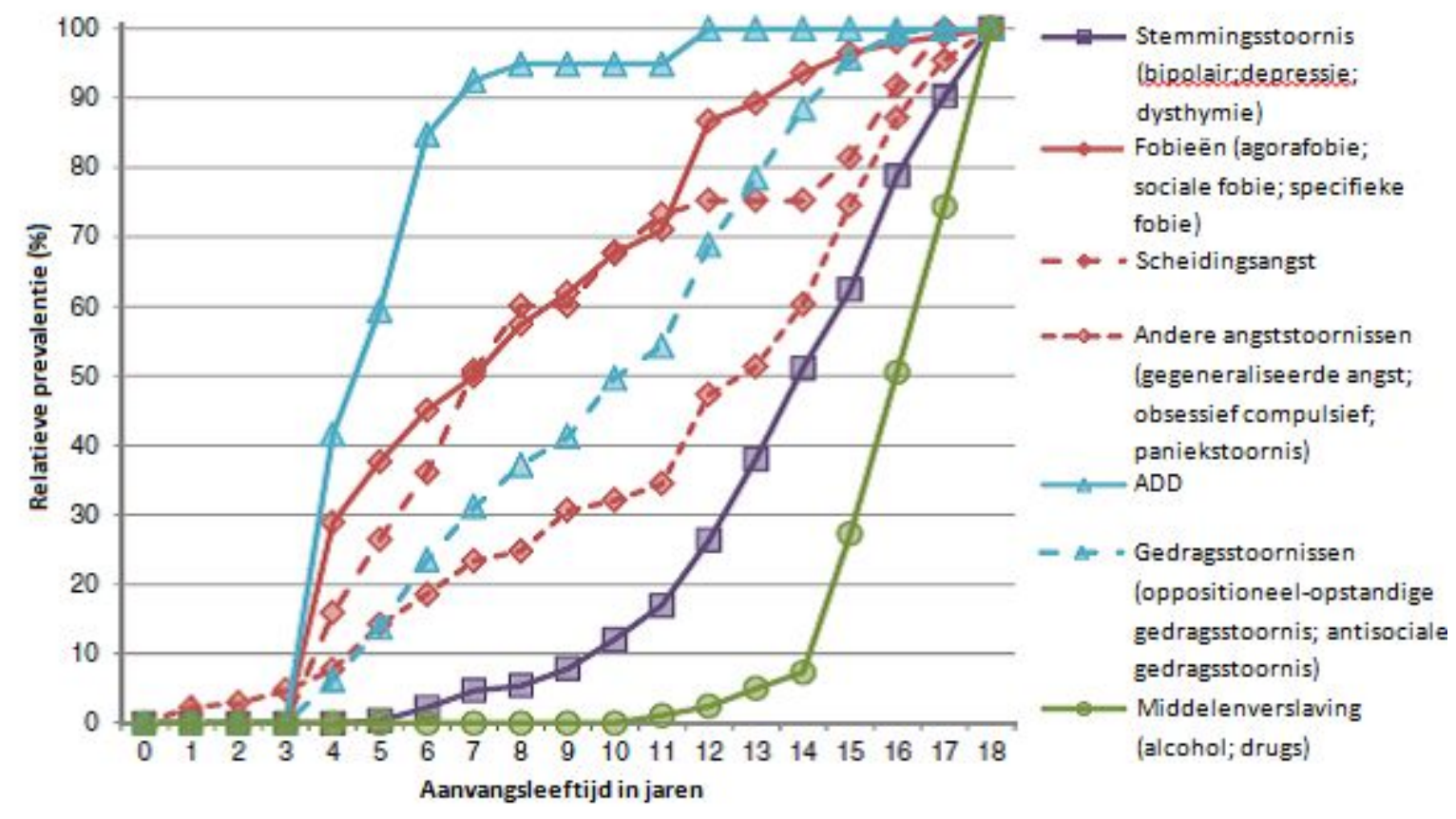

Figuur 2: De cumulatieve prevalentie van elke stoornis per leeftijdsjaar Bron figuur 2: Ormel et al. (2015).

Toelichting Figuur 2: In een groep met jongeren (11-19 jarigen) die leiden aan een stoornis is bepaald wanneer de stoornis is begonnen. Bijv. op 16 jarigen leeftijd is er voor middelenverslaving een relatieve prevalentie van 50\%, ofwel 50\% van de kinderen die nu 19 jaar oud zijn met een middelenstoornis hadden deze verslaving al op 16 jarige leeftijd.

\section{Gehechtheid en psychosociale problemen}

De ontwikkeling van een gehechtheidsrelatie in het eerste levensjaar is een noodzakelijke stap in de ontwikkeling van het jonge kind (Bateman \& Fonagy, 2012). Een gehechtheidsrelatie is een duurzame band tussen een kind en zijn ouder(s), die in het 1e levensjaar wordt opgebouwd en daarna voortdurend wordt bijgesteld op basis van opgedane ervaringen (Bowlby, 1988). In een veilige gehechtheidsrelatie heeft het kind vertrouwen opgebouwd in de beschikbaarheid van de ouderfiguur. In een onveilige relatie ontbreekt dat vertrouwen. Kinderen die onveilig-vermijdend gehecht zijn, zien hun ouders als 'niet-beschikbaar' en hebben geleerd om zelf alle 'moeilijkheden' op te lossen. Naar schatting $62 \%$ van alle gezonde, thuiswonende kinderen in Nederland heeft een veilige gehechtheidsrelatie, en $38 \%$ een onveilige gehechtheidsrelatie (van IJzendoorn \& Kroonenberg, 1988; de Wolff et al., 2012; zie jeugdhulp richtlijn Problematische Gehechtheid) . De onveilige groep heeft een verhoogd risico op psychosociale problemen. Uiteindelijk ontwikkelt ongeveer $15 \%$ van de kinderen en jongeren met een onveilige gehechtheidsrelatie meer ernstige problematiek, in de zin dat hun ontwikkeling bedreigd wordt door de gehechtheidsproblemen. Het gaat om kinderen die in een meer kwetsbare positie verkeren door een combinatie van risicofactoren zoals psychiatrische problematiek bij de ouder, adoptie, of een ontwikkelingsstoornis bij het kind. Juist deze groep heeft een verhoogd risico op het ontwikkelen van psychopathologie (Bateman \& Fonagy, 2012).

Een onveilige gehechtheidsrelatie moet gezien worden als een risicofactor in de sociaal-emotionele ontwikkeling van de jeugdige (Schuengel \& Sterkenburg, 2004). Onderzoek heeft aangetoond dat internaliserende problemen iets vaker voorkomen bij kinderen en jongeren 
met een onveilig-vermijdende gehechtheidsrelatie (Groh et al., 2012). Verder is gebleken dat met name jongens die een gedesorganiseerde gehechtheidsrelatie hebben meer gedragsproblemen kunnen ontwikkelen (Fearon et al., 2010). Er is sprake van een gedesorganiseerde gehechtheidsrelatie als de ouder enerzijds een bron van steun is voor het kind, maar tegelijk ook een bron van angst doordat de ouder last heeft van trauma's of psychiatrische problematiek.

Om de samenhang tussen gehechtheid en psychosociale problemen te verklaren wordt het intern werkmodel', of mentale representatie van gehechtheid gebruikt. Door gehecht te raken aan één of meer volwassenen, bouwt een kind een mentaal beeld op van mensen in het algemeen - dat kan een beeld zijn van beschikbaarheid en hulpvaardigheid of van ontoegankelijkheid en afwijzing (Van IJzendoorn \& Bakermans, 2010). Het werkmodel van gehechtheid vormt de blauwdruk voor de sociale relaties die een kind opbouwt. Verondersteld wordt dat het werkmodel de verwerking van informatie over relaties en emotionele gebeurtenissen in een belangrijke mate stuurt. Personen met een onveilig model van gehechtheid, nemen anderen eerder als vijandig of onbetrouwbaar waar en hebben een negatiever zelfbeeld (Van IJzendoorn \& Bakermans, 2010).

\section{Gevolgen van psychosociale problemen}

\section{Samenhang tussen psychosociale problemen en andere ontwikkelingsgebieden van een kind}

De ontwikkeling van kinderen is gebaseerd op een voortdurende interactie tussen het kind, de ouders en overige omgevingsfactoren. De ontwikkeling van kinderen wordt beschreven in verschillende domeinen (fysiek, motoriek, taal, cognitief, etc.). Psychosociale problemen, en de daarmee samenhangende opvoedingsproblemen, hebben altijd een wisselwerking met de verschillende ontwikkelingsdomeinen van het kind. Fysieke problemen kunnen een kenmerk zijn van psychosociale problematiek, maar ook de oorzaak hiervan. Zo is er bijvoorbeeld aangetoond dat astma (Chen et al., 2014), of een licht verstandelijke beperking (Oeseburg, 2010) of slaapproblemen (Astill et al., 2012) kunnen leiden tot psychosociale problemen (zie ook Thema 1). Omgekeerd kunnen psychosociale problemen invloed hebben op de cognitieve ontwikkeling van een kind (spraak-/taal en leerproblemen problemen) (Lindsay et al., 2007; Veldman et al., 2014). De mate waarin psychosociale problematiek invloed heeft op andere ontwikkelingsgebieden hangt af van de aard, duur en frequentie van de problemen, en daarnaast van de leeftijd en het ontwikkelingsniveau van het kind. Ernstige psychosociale problemen kunnen gevolgen hebben voor de ontwikkeling van de anatomische structuren in het brein (prefrontale cortex, hippocampus, amygdala, corpus callosum en cerebellum) (Brunner \& Marmot, 2006). Bovendien bestaat er neuro-endocrinologisch een sterke associatie tussen ernstige psychosociale problematiek en de stress-respons: disfunctie van de hypothalamus-hypofyse-bijnier-as (HPA-as) en de hiermee samenhangende (neuro)ontwikkelingsstoornissen (Charles et al., 2009). Verstoringen in deze stress-as betreffen verstoorde verhoudingen van stresshormonen, waaronder cortisol, die leiden tot een permanente staat van alertheid ten dienste van een snelle vlucht-vechtreactie bij stress (McCrory et al., 2010; Teicher et al., 2003).

\section{Problemen in de jeugd zijn voorspellend voor problemen tijdens volwassenheid} Uit verscheidene longitudinale studies komt naar voren dat emotionele en gedragsproblemen in de jeugd vaak een voorbode zijn van stoornissen bij (jong)volwassenen. In veel gevallen duren ze voort tot in de late adolescentie en de volwassenheid (Hofstra et al., 2002; Reef et al., 2009). Hofstra (2002) heeft gevonden dat gedrag en emotionele problemen tijdens de kindertijd (4 tot 16 jaar) gerelateerd zijn aan DSM diagnoses 14 jaar later. Reef en collega's laten zien dat kinderen 
met angst- of depressieklachten, agressief of delinquent gedrag 1,5 tot twee keer meer risico hebben op psychosociale problemen 24 jaar later (Reef et al., 2009). Daarnaast verhogen ernstige emotionele problemen, en voornamelijk somberheidgevoelens, (later) de kans op suïcide (Bool et al., 2007).

\section{Economische kosten en maatschappelijke participatie}

De economische kosten van psychische gezondheidsproblemen zijn hoog . Smith en Smith (2010) hebben berekend dat deze problemen in de Verenigde Staten leiden tot een reductie van het gezinsinkomen van ongeveer 10.000 doller per jaar. Verder hebben psychosociale problemen invloed op de maatschappelijke participatie. Veldman (2014) heeft gevonden dat externaliserende, internaliserende en aandachtsproblemen op de leeftijd van 11 jaar een voorbode zijn voor een lage opleiding op de leeftijd van 19 jaar. Deze resultaten zijn vergelijkbaar met studies uit de Verenigde Staten (Breslau et al, 2008,2011; Miech et al., 1999).

\section{Referenties}

Astill, R. G., Van der Heijden, K. B., Van ljzendoorn, M. H., \& Van Someren, E. J. (2012). Sleep, cognition, and behavioral problems in school-age children: A century of research meta-analyzed. Psychological Bulletin, 138(6), 1109-1138.

Bakker, I., K. Bakker (1997). O + O². Naar een samenhangend beleid en aanbod van opvoedingsondersteuning en ontwikkelingsstimulering voor ouders en kinderen in risicosituaties. Utrecht: NIZW.

Bakker, I., K. Bakker (1998). O \& O in perspectief. Utrecht: NIZW.

Bateman, A. \& Fonagy, P. (2012). Handbook of mentalizing in mental health practice. Washington: American Psychiatric Publishing.

Bernstein DA, Clarke-Stewart A, Roy EJ, Wickens CD (1997). Psychology. New York: Houghton Mifflin Company.

Boer F, Verhulst F (2014). Kompas Kinder-en Jeugd-psychiatrie. De Tijdstroom, Utrecht.

Bool M, Blekman J, Jong S de, Ruiter M, Voordouw I.Verminderen van suïcidaliteit. Beleidsadvies Acualisering van het Advies inzake Suïcide, Gezondheidsraad 1986. Utrecht: Trimbos-instituut, 2007.

Bot M, de Leeuw den Bouter BJ, Adriaanse MC. Prevalence of psychosocial problems in Dutch children aged 8- 12 years and its association with risk factors and quality of life. Epidemiol Psychiatr Sci 2011;20:357-65.

Bowlby, J. (1988). A secure base. Clinical applications of attachment theory. London: Routledge.

Breslau J, Lane M, Sampson N, Kessler RC (2008) Mental disorders and subsequent educational attainment in a US national sample. J Psychiatr Res 42: 708-716.

Breslau J, Miller E, Joanie Chung W-J, Schweitzer JB (2011) Childhood and adolescent onset psychiatric disorders, substance use, and failure to graduate high school on time. J Psychiatr Res 45: 295-301.

Brunner E \& Marmot MG (2006). 'Social organization, stress, and Health.' In M.G. Marmot \& R.G. Wilkinson (Eds.), Social Determinants of Health. Oxford; Oxford University.

Chen, J. (2014). Asthma and child behavioral skills: Does family socioeconomic status matter? Social Science \& Medicine, 115 Aug, 38-48.

Dorsselaer, S., E. Zeijl, S. van den Eeckhout, T. ter Bogt, W. Vollebergh (2007). HBSC 2005. Gezondheid en welzijn van jongeren in Nederland. Utrecht: Trimbos instituut.

Engel, G.L. (1980). The clinical application of the biopsychosocial model. The American Journal of Psychiatry, 137, 535-544. 
Fearon, R. P., Bakermans-Kranenburg, M. J., van IJzendoorn, M. H., Lapsley, A., \& Roisman, G. I. (2010). The significance of insecure attachment and disorganization in the development of children's externalizing behavior: A meta-analytic study. Child Development, 81, 435-456.

Gillespie CF, Phifer J, Bradley B \& Ressler KJ. Risk and resilience: genetic and environmental influences on development of the stress response. Depression and Anxiety 2009, 26, 984-992.

Groh, A. M., Roisman, G. I., van IJzendoorn, M. H., Bakermans-Kranenburg, M. J., \& Fearon, R. P. (2012). The significance of insecure and disorganized attachment for children's internalizing symptoms: A meta-analytic study. Child Development, 83, 591-610.

Hofstra MB, Ende J van der, Verhulst FC.Child and adolescent problems predict DSM-IV disorders in adulthood: A 14-year follow-up of a Dutch epidemiological sample. J Am Acad Child Adolesc Psychiatry, 2002; 41: 182-189.

Lindsay, G., Dockrell, J.E. \& Strand, S. (2007). Longitudinal patterns of behaviour problems in children with specific speech and language difficulties: Child and contextual factors. British Journal of Educational Psychology, 77, 811-828.

McCrory E, De Brito SA, Viding E. Research review: the neurobiology and genetics of maltreatment and adversity. J Child Psychol Psychiatr 2010; 51(10): 1079-1095.

Miech RA, Caspi A, Moffitt TE, Wright BRE, Silva PA (1999) Low Socioeconomic Status and Mental Disorders: A Longitudinal Study during Young Adulthood. Am J Sociol 104: 1096-1131.

Oeseburg, B., Jansen, D. E., Groothoff, J. W., Dijkstra, G. J., \& Reijneveld, S. A. (2010). Emotional and behavioural problems in adolescents with intellectual disability with and without chronic diseases. Journal of Intellectual Disability Research, 54(1), 81-89.

Ormel J, Raven D, van Oort F, Hartman CA, Reijneveld SA, Veenstra R, Vollebergh WAM, Buitelaar $J$, Verhulst FC, Oldehinkel AJ. Mental health in Dutch adolescents: a TRAILS report on prevalence, severity, age of onset, continuity and co-morbidity of DSM disorders. Psychological Medicine (2015), 45, 345-360.

Postma . JGZ-richtlijn vroegsignalering van psychosociale problemen. RIVM, Centrum Jeugdgezondheid, Bilthoven:2008.

Ploeg, JD van der (2007). Gedragsproblemen: ontwikkelingen en risico's. Rotterdam: Lemniscaat

Reef J, Diamantopoulou S, van Meurs I, Verhulst F, van der Ende J. Child to adult continuities of psychopathology: a 24-year follow-up. Acta Psychiatr Scand, 2009;120(3):230-8.

Reijneveld S.A., A.G.C. Vogels, F. Hoekstra, M.R.Crone (2006). Use of the Pediatric Symptom Checklist for the detection of psychosocial problems in preventive child healthcare. BMC Public Health, 6, 1471-2458.

Schoemaker C, De Ruiter C, Van den Berg M, Cuijpers P, De Graaf R, Ten Have M. Nationale monitor geestelijke gezondheid: jaarboek 2003: ADHD, anorexia nervosa en andere psychische stoornissen. Utrecht: Trimbos-instituut, 2003.

Schuengel, C. \& Sterkenburg, P. S. (2004). Gehechtheid als gemeenschappelijk terrein voor psychotherapie en orthopedagogiek. Kinder- \& Jeugdpsychotherapie, 4, 40-58.

Smith JP, Smith GC (2010) Long-term economic costs of psychological problems during childhood. Soc Sci Med 71: 110-115.

Sroufe, LA, Cooper, RG, DeHart, GB (1996). Child development. Its nature and course. New York: McGraw-hill, inc.

Sroufe, L. A., Egeland, B., Carlson, E. A., \& Collins, W. A. (2005). The development of the person: The Minnesota study of risk and adaptation from birth to adulthood. New York: Guilford.

Stevens, G.W. and W.A.M. Vollebergh, Mental Health in migrant children. J Child Psychol

Psychiatry,

2008. 49(3): p. 276-294. 
Teicher MH, Andersen SL, Polcari A, Anderson CM, Navalta CP, Kim DM. The neurobiological consequences of early stress and childhood maltreatment. Neurosc Behav Rev 2003; 27: 33-44.

Theunissen M, Vogels A, de Wolff M, Reijneveld SA. Characteristics of the Strengths and

Difficulties

Questionnaire in Pre-school Children. Pediatrics 2013, 131 (2):1-9.

van den Dries, L., Juffer, F., van IJzendoorn, M. H., \& Bakermans-Kranenburg, M. J. (2009).

Fostering security? A meta-analysis of attachment in adopted children. Children and Youth

Services Review, 31, 410-421.

Van Steijn L, de Winter AF, Reijneveld SA (2014). Stabiliteit en verandering van psychosociale gezondheid en leefstijl bij adolescenten en mogelijkheden voor interventies. Bouwstenen voor het Extra Contactmoment Adolescenten. Groningen: UMCG, Rijksuniversiteit Groningen.

van IJzendoorn, M. H. \& Kroonenberg, P. M. (1988). Cross-cultural patterns of attachment. A meta-analysis of the Strange Situation. Child Development, 59, 147-156.

van IJzendoorn, M.H. \& Juffer, F. (2006). The Emanuel Milller Memorial Lecture. Adoption as intervention. Meta-analytic evidence for massive catch-up and plasticity in physical, socioemotional, and cognitive development. Journal of Child Psychology and Psychiatry, 47, 1228 - 1245.

van IJzendoorn, M.H. \& Bakermans-Kranenburg, M. J. (2010). Gehechtheid en trauma. Amsterdam: Hogrefe.

Veldman K, Bultmann U, Stewart RE, Ormel J, Verhulst FC, Reijneveld SA. Mental Health Problems and Educational Attainment in Adolescence: 9-Year Follow-Up of the TRAILS Study. Plos One, 2014; 9 (7). e101751

Vogels AG, Crone MR, Hoekstra F, Reijneveld SA. Comparing three short questionnaires to detect psychosocial dysfunction among primary school children: A randomized method. BMC Public Health. 2009;9(1):489.

Zeijl, E., M. Crone, K. Wiefferink, S. Keuzenkamp, M. Reijneveld (2005). Kinderen in Nederland. Den Haag/Leiden: SCP/TNO. 


\section{Thema 1 Risico- en beschermende factoren}

\section{Inleiding}

In dit hoofdstuk brengen we in kaart welke risico- en beschermende factoren voor het ontwikkelen van psychosociale problemen uit de onderzoeksliteratuur bekend zijn. Risicofactoren omschrijven we hier als factoren (gedragingen, omstandigheden, kenmerken) die de ontwikkeling van psychosociale problemen bij een kind voorspellen of de kans op het voorkomen van psychosociale problemen binnen een bepaalde populatie vergroten (Kraemer, Stice, Kazdin, Offord, \& Kupfer, 2001). Volgens het biopsychosociale model (Engel, 1980) spelen altijd meerdere risicofactoren een rol in het ontstaan van psychosociale problemen. In de bespreking van de risicofactoren maken we onderscheid tussen het micro- meso- en macrosysteem die van invloed zijn op de ontwikkeling van een kind. In het microsysteem gaat het om factoren in het kind, de ouder of het gezin zelf; in het mesosysteem gaat het met name om sociale gezinsfactoren, de buurt en de school. In het macrosysteem tenslotte staan factoren in de grotere omgeving verder weg centraal, zoals de sociaaleconomische omstandigheden, cultuur, en de maatschappij als geheel.

\section{Aanbevelingen}

De risico- en beschermende factoren zijn gerangschikt van hoog naar laag niveau van wetenschappelijk bewijs. Cursief gedrukte risico- en beschermende factoren hebben een lage bewijslast. Dit betekent dat er in de literatuur aanwijzingen gevonden zijn dat de betreffende factor een risico-of beschermende factor kan zijn voor psychosociale problemen, maar dat dit nog niet met harde bewijzen is aangetoond.

- Wees extra alert op psychosociale problemen in de volgende situaties:

o wanneer de jeugdige...

- matig prematuur (32-36 weken) of ernstig prematuur (<32 weken) geboren is of een laag geboortegewicht heeft ( gewicht $<1500$ gram)

- een geremd, prikkelbaar temperament heeft (moeilijk of minder sociaal)

- een ongeremd, extrovert temperament heeft dat gekenmerkt wordt door lage aandachtsspanne

- een chronische somatische aandoening heeft

- een (licht) verstandelijke beperking (LVB) heeft

0

wanneer bij één of beide ouder(s) sprake is van

- een chronische somatische aandoening

- psychiatrische en/of verslavingsproblematiek zoals (postpartum)depressie bij moeder of depressie/ADHD/middelengebruik bij de vader

- moeder die in haar jeugd mishandeling heeft meegemaakt

- alcoholgebruik bij moeder (1 tot 3 glazen per week) of actief roken van moeder tijdens de zwangerschap

- een van de volgende opvoedstijlen: vijandig, afwijzend, gebruik makend van strenge straffen of overbeschermend

- weinig vertrouwen in de eigen opvoedcompetenties

o wanneer sprake is van 
- een onveilig vermijdende of gedesorganiseerde gehechtheidsrelatie tussen ouder en kind

- een éénouder gezin

- ingrijpende gebeurtenissen zoals echtscheiding

- een lage Sociaal Economische Status (SES, lage opleiding en/of laag inkomen) in het gezin

- een achtergestelde woonomgeving (wijk met veel werkeloosheid, laag inkomen en laag opleidingsniveau)

- een allochtone achtergrond bij één van de ouders (dwz: afkomstig uit niet-geïndustrialiseerde landen zoals Suriname en Antillen) of één van de ouders een economische immigrant is (o.a. Polen, Turken en Marokkanen).

- een gevlucht of een asielzoekersgezin dat vaker dan 1 keer in een jaar verhuist; of waarin het kind blootgesteld is geweest aan geweld

- Weet dat externaliserende problemen vaker voorkomen bij jongens en dat tijdens de adolescentie internaliserende problemen vaker voorkomen bij meisjes.

- De werkgroep is van mening dat een (licht) verstandelijke beperking (LVB) bij één of beide ouder(s) kan samenhangen met psychosociale problemen bij de kinderen. Raadpleeg de Handreiking LVB hoe deze ouders te herkennen zijn [LINK naar Handreiking LVB]). Indien sprake is van LVB bij één of beide ouder(s), dan is het - nog meer dan bij andere gezinnen - wenselijk om in gesprek te gaan met de ouders, het sociale netwerk in kaart te brengen en het gezin te monitoren om de opvoeding en ontwikkeling van het kind te volgen.

- Weet dat de volgende beschermende factoren de negatieve werking van risicofactoren kunnen inperken :

- intelligent kind

- veel zelfvertrouwen bij het kind

- warme, sensitieve opvoedstijl (zoals acceptatie en responsiviteit) van moeder

- $\quad$ een goede band tussen ouder en kind

- sociale steun van het informele netwerk van ouders

- Indien sprake is van 2 of meer risicofactoren in een gezin:

- $\quad$ Bespreek dit met de ouder(s) en registreer de aanwezigheid van de risicofactoren in het DD JGZ.

- Weeg samen met ouder(s)/jeugdige de risico- en beschermende factoren af

- Bespreek of de ouder(s)/jeugdige behoefte hebben aan aanvullende steun

3. Uitgangsvraag

- Wat zijn risico- en beschermende factoren voor het ontwikkelen van psychosociale problemen, tijdens de zwangerschap en daarna? 


\section{Onderbouwing}

\section{Risicofactoren op microniveau: kind}

\section{Prematuriteit}

\begin{tabular}{|l|l|l|}
\hline Niveau & Conclusie & Literatuur \\
\hline 1 & $\begin{array}{l}\text { Het is aangetoond dat matig premature kinderen (32-37 weken) en } \\
\text { zeer premature kinderen (< 32 weken; of met een geboortegewicht } \\
\text { onder } \mathbf{1 5 0 0} \text { gram) meer emotionele en gedragsproblemen hebben dan } \\
\text { voldragen kinderen }\end{array}$ & $\begin{array}{l}\text { A1 (Arpi \& Ferrari, } \\
\text { A2 (van Baar et al., } \\
\end{array}$ \\
& $\begin{array}{l}\text { 2009; Reijneveld et } \\
\text { al., 2006; Potijk et } \\
\text { al., 2012; Talge et } \\
\text { al., 2010) }\end{array}$ \\
\hline
\end{tabular}

\section{Temperament kind}

\begin{tabular}{|c|c|c|}
\hline Niveau & Conclusie & Literatuur \\
\hline 2 & $\begin{array}{l}\text { Het is aannemelijk dat kinderen met een geremd temperament vaker } \\
\text { een angststoornis hebben }\end{array}$ & $\begin{array}{l}\text { A2 (Schwartz et al., } \\
1999) \\
\text { C (Biederman et al., } \\
2011)\end{array}$ \\
\hline 2 & $\begin{array}{l}\text { Het is aannemelijk dat kinderen met een moeilijk, prikkelbaar } \\
\text { temperament vaker psychiatrische symptomen hebben in de adolescentie }\end{array}$ & $\begin{array}{l}\text { A2 (Teerikangas et } \\
\text { al., 1998) }\end{array}$ \\
\hline 2 & $\begin{array}{l}\text { Het is aannemelijk dat kinderen met een temperament dat gekenmerkt } \\
\text { wordt door een lage aandachtsspanne vaker externalizerende } \\
\text { problemen hebben }\end{array}$ & $\begin{array}{l}\text { A2 (Caspi et al., } \\
1995)\end{array}$ \\
\hline 3 & $\begin{array}{l}\text { Er is een aanwijzing dat kinderen met een niet-geremd temperament } \\
\text { vaker een disruptieve gedragsstoornis en vaker aandachtsproblemen } \\
\text { hebben }\end{array}$ & $\begin{array}{l}\text { C (Biederman et al., } \\
\text { 2011) }\end{array}$ \\
\hline 2 & $\begin{array}{l}\text { Het is aannemelijk dat kinderen met een extrovert temperament vaker } \\
\text { hyperactiviteit en agressie laten zien }\end{array}$ & $\begin{array}{l}\text { A2 (Berdan et al., } \\
\text { 2002) }\end{array}$ \\
\hline
\end{tabular}

\section{Leeftijd kind}

\begin{tabular}{|l|l|l|} 
Niveau & $\begin{array}{l}\text { Conclusie } \\
3\end{array}$ & $\begin{array}{l}\text { Er is een aanwijzing dat psychosociale problemen in de kindertijd } \\
\text { toenemen } \\
\text { Er is een aanwijzing dat externalizerende problemen in de adolescentie } \\
\text { eerst toe, en daarna weer afnemen } \\
\text { Er is een aanwijzing dat hyperactiviteit in de adolescentie vaker voorkomt } \\
\text { dan in de kindertijd } \\
\text { Er is een aanwijzing dat emotionele problemen toenemen naarmate } \\
\text { adolescenten ouder worden } \\
\text { Er is een aanwijzing dat weinig prosociaal gedrag toeneemt naarmate } \\
\text { adolescenten ouder worden }\end{array}$
\end{tabular}




\section{Geslacht kind}

\begin{tabular}{|l|l|l|} 
Niveau & Conclusie & Literatuur \\
& $\begin{array}{l}\text { Er zijn aanwijzingen dat meisjes vaker internaliserende problemen } \\
\text { hebben }\end{array}$ & $\begin{array}{l}\text { C (van Dorsselaer et } \\
\text { al., 2010; van Steijn } \\
\text { et al., 2014; }\end{array}$ \\
& Zahn-Waxler et al., \\
3 & Er zijn aanwijzingen dat jongens vaker externaliserende problemen & 2008) \\
C (van Dorsselaer et \\
& hebben & al., 2010; Kerr et \\
& & al., 2004; \\
& Zahn-Waxler et al., \\
& & $2008)$ \\
\hline
\end{tabular}

\section{Chronische ziekten en verstandelijke beperking van het kind}

\begin{tabular}{|c|c|c|}
\hline Niveau & Conclusie & Literatuur \\
\hline 2 & $\begin{array}{l}\text { Het is aannemelijk dat kinderen met een slechte fysieke gezondheid } \\
\text { vaker internaliserende problemen hebben }\end{array}$ & $\begin{array}{l}\text { A2 (Bayer et al., } \\
\text { 2011) }\end{array}$ \\
\hline 3 & $\begin{array}{l}\text { Er zijn aanwijzingen dat kinderen met een chronische aandoening } \\
\text { vaker psychosociale problemen hebben }\end{array}$ & $\begin{array}{l}\text { C (Bilfield et al., } \\
\text { 2006; Bot et al., } \\
\text { 2011) }\end{array}$ \\
\hline 3 & $\begin{array}{l}\text { Er is een aanwijzing dat kinderen met astma vaker externalizerende } \\
\text { problemen hebben, alleen als zij een laagopgeleide moeder hebben en in } \\
\text { armoede opgroeien }\end{array}$ & C (Chen, 2014) \\
\hline 3 & $\begin{array}{l}\text { Er is een aanwijzing dat kinderen met een verstandelijke beperking } \\
\text { vaker psychosociale problemen hebben }\end{array}$ & $\begin{array}{l}\text { C (Kaptein et al., } \\
\text { 2014) }\end{array}$ \\
\hline 3 & $\begin{array}{l}\text { Er is een aanwijzing dat kinderen met een chronische aandoening en } \\
\text { een verstandelijke beperking, vaker emotionele en gedragsproblemen } \\
\text { hebben dan kinderen met een verstandelijke beperking zonder chronische } \\
\text { aandoening }\end{array}$ & $\begin{array}{l}\text { C (Oeseburg et al., } \\
2008)\end{array}$ \\
\hline
\end{tabular}

\section{Risicofactoren microniveau: ouder}

\section{Chronische somatische aandoening van de ouder}

\begin{tabular}{|c|c|c|}
\hline Niveau & Conclusie & Literatuur \\
\hline 1 & $\begin{array}{l}\text { Het is aangetoond dat kinderen van ouders met een chronisch } \\
\text { somatische aandoening significant meer internaliserend en } \\
\text { externaliserend probleemgedrag laten zien dan kinderen van gezonde } \\
\text { ouders. }\end{array}$ & $\begin{array}{l}\text { A1 (Sieh, et al; } \\
\text { 2010) }\end{array}$ \\
\hline 2 & $\begin{array}{l}\text { Het is aannemelijk dat adolescenten met ouders die lijden aan een } \\
\text { chronische somatische aandoening meer internaliserend gedrag laten } \\
\text { zien dan kinderen van gezonde ouders, en slechtere schoolprestaties } \\
\text { hebben in vergelijking met kinderen van gezonde ouders. }\end{array}$ & $\begin{array}{l}\text { A2 (Sieh, } \\
\text { Visser-Meily, \& } \\
\text { Meijer, 2013) }\end{array}$ \\
\hline 3 & $\begin{array}{l}\text { Er is een aanwijzing dat basisschoolkinderen en adolescente dochters } \\
\text { van een ouder met kanker een verhoogd risico hebben op emotionele } \\
\text { problemen. }\end{array}$ & $\begin{array}{l}\text { A2 (Visser et al., } \\
2004)\end{array}$ \\
\hline
\end{tabular}


Psychische gesteldheid van de ouders en verslavingsproblematiek

\begin{tabular}{|c|c|c|}
\hline Niveau & Conclusie & Literatuur \\
\hline 1 & $\begin{array}{l}\text { Het is aangetoond dat kinderen met moeders met een depressie vaker } \\
\text { emotionele- en gedragsproblemen hebben }\end{array}$ & $\begin{array}{l}\text { A1 (Beck, } 1999 \\
\text { Goodman et al., } \\
\text { 2011) }\end{array}$ \\
\hline 1 & $\begin{array}{l}\text { Het is aangetoond dat kinderen van wie de ouders een angststoornis of } \\
\text { depressie hebben een verhoogd risico hebben op emotionele problemen. }\end{array}$ & $\begin{array}{l}\text { A1 (Biederman et } \\
\text { al., 2001) }\end{array}$ \\
\hline 2 & $\begin{array}{l}\text { Het is aannemelijk dat adolescenten met een moeder met een } \\
\text { postnatale depressie vaker angststoornissen hebben }\end{array}$ & $\begin{array}{l}\text { A2 (Halligan et al., } \\
\text { 2007) }\end{array}$ \\
\hline 2 & $\begin{array}{l}\text { Het is aannemelijk dat adolescenten van wie de moeder leed aan een } \\
\text { postnatale depressie zelf vaker een depressie ontwikkelen, maar alleen } \\
\text { als hun moeder ook in latere episodes last had van depressies }\end{array}$ & $\begin{array}{l}\text { A2 (Halligan et al., } \\
\text { 2007) }\end{array}$ \\
\hline 2 & $\begin{array}{l}\text { Het is aannemelijk dat antenatale depressie van de moeder het risico op } \\
\text { kindermishandeling in de basisschoolleeftijd aanmerkelijk vergroot; en } \\
\text { dat een combinatie van antenatale depressie en mishandeling op de } \\
\text { basisschoolleeftijd de kans op psychopathologie aanmerkelijk verhoogt. }\end{array}$ & $\begin{array}{l}\text { A2 (Pawlby et al, } \\
\text { 2011) }\end{array}$ \\
\hline 2 & $\begin{array}{l}\text { Het is aannemelijk dat kinderen met moeders met een eerder of huidig } \\
\text { mentaal gezondheidsrisico vaker internaliserende problemen hebben. }\end{array}$ & $\begin{array}{l}\text { A2 (Cabaj et al., } \\
\text { 2004) }\end{array}$ \\
\hline 2 & $\begin{array}{l}\text { Het is aannemelijk dat kinderen met ouders met psychopathologie } \\
\text { vaker internaliserende problemen hebben }\end{array}$ & $\begin{array}{l}\text { A2 (Ashford et al., } \\
\text { 2008; Bayer et al, } \\
\text { 2011) }\end{array}$ \\
\hline 2 & $\begin{array}{l}\text { Het is aannemelijk dat kinderen met een moeder met een psychotische } \\
\text { of niet-psychotische postnatale depressie vaker een onveilige } \\
\text { gehechtheidsrelatie met hun moeder hebben. }\end{array}$ & $\begin{array}{l}\text { A2 (Hipwell et al., } \\
\text { 2000) }\end{array}$ \\
\hline 2 & $\begin{array}{l}\text { Het is aannemelijk dat kinderen met een vader met eerdere } \\
\text { depressieve symptomen vaker internaliserende, externaliserende en } \\
\text { sociale problemen hebben. }\end{array}$ & $\begin{array}{l}\text { A2 (Herbert et al., } \\
\text { 2013) }\end{array}$ \\
\hline 2 & $\begin{array}{l}\text { Het is aannemelijk dat kinderen van wie één of beide ouders lijden aan } \\
\text { psychische stoornissen (waaronder middelen stoornis) significant } \\
\text { vaker zelf ook lijden aan psychische stoornissen. }\end{array}$ & $\begin{array}{l}\text { A2 (McLaughlin et } \\
\text { al., 2012) }\end{array}$ \\
\hline 3 & $\begin{array}{l}\text { Er is een aanwijzing dat kinderen die opgroeien in een gezin waarbij } \\
\text { de vader lijdt aan een verslaving (al dan niet in combinatie met een } \\
\text { psychische stoornis) een vergrote kans hebben op psychopathologie. }\end{array}$ & $\begin{array}{l}\text { C (Clark, et al., } \\
2004)\end{array}$ \\
\hline 3 & $\begin{array}{l}\text { Er is een aanwijzing dat volwassen kinderen van alcoholisten } \\
\text { significant vaker zelf lijden aan psychische stoornissen (waaronder } \\
\text { middelen stoornis); bovendien openbaren de stoornissen zich op jongere } \\
\text { leeftijd ivm vergeljikingsgroep. }\end{array}$ & $\begin{array}{l}\text { C (Cuijpers, et al., } \\
\text { 1999) }\end{array}$ \\
\hline 3 & $\begin{array}{l}\text { Er is een aanwijzing dat kinderen met life stress vaker emotionele en } \\
\text { gedragsproblemen hebben. }\end{array}$ & $\begin{array}{l}\text { B (Flouri et al., } \\
\text { 2013) }\end{array}$ \\
\hline
\end{tabular}

\section{Verleden mishandeling ouders}

\begin{tabular}{|l|l|l|}
\hline Niveau & $\begin{array}{l}\text { Conclusie } \\
2\end{array}$ & $\begin{array}{l}\text { Het is aannemelijk dat kinderen met een moeder die } \\
\text { kindermishandeling heeft meegemaakt vaker externalizerende } \\
\text { problemen hebben. }\end{array}$ \\
$\begin{array}{l}\text { Het is aannemelijk dat adolescenten met een moeder die } \\
\text { kindermishandeling heeft meegemaakt én een depressie tijdens de } \\
\text { zwangerschap heeft gehad, vaker antisociaal gedraag vertonen }\end{array}$ & $\begin{array}{l}\text { A2 (Plant et al., } \\
2013)\end{array}$ \\
\hline
\end{tabular}




\section{Middelengebruik tijdens de zwangerschap}

\begin{tabular}{|c|c|c|}
\hline Niveau & Conclusie & Literatuur \\
\hline 2 & $\begin{array}{l}\text { Het is aannemelijk dat kinderen waarvan de moeder rookte tijdens de } \\
\text { zwangerschap vaker } A D H D \text { hebben }\end{array}$ & $\begin{array}{l}\text { A2 (Monshouwer et } \\
\text { al., 2011) } \\
\text { B (Motlagh et al., } \\
\text { 2011) }\end{array}$ \\
\hline 2 & $\begin{array}{l}\text { Het is aannemelijk dat kinderen van wie de moeder rookte tijdens de } \\
\text { zwangerschap meer internaliserend en externaliserend probleemgedrag } \\
\text { laten zien }\end{array}$ & $\begin{array}{l}\text { A2 (Ashford et al, } \\
\text { 2008a) }\end{array}$ \\
\hline 2 & $\begin{array}{l}\text { Het is aannemelijk dat kinderen waarvan de moeder alcohol dronk } \\
\text { (1-3 keer per week) tijdens de zwangerschap vaker psychosociale } \\
\text { problemen hebben }\end{array}$ & $\begin{array}{l}\text { A2 (Alvik et al., } \\
\text { 2013) }\end{array}$ \\
\hline
\end{tabular}

(Licht) Verstandelijke beperking ouders

\begin{tabular}{|l|l|l|}
\hline Niveau & Conclusie & Literatuur \\
\hline 4 & $\begin{array}{l}\text { (Licht) verstandelijke beperking van de ouder(s) kan een risicofactor zijn } \\
\text { voor psychosociale problemen bij het kind. }\end{array}$ & $\begin{array}{l}\text { Mening van de } \\
\text { werkgroep }\end{array}$ \\
\hline
\end{tabular}

\section{Risicofactoren microniveau: ouder-kind interactie}

\begin{tabular}{|c|c|c|}
\hline Niveau & Conclusie & Literatuur \\
\hline 1 & $\begin{array}{l}\text { Het is aangetoond dat een onveilige gehechtheid samenhangt met } \\
\text { externaliserende gedragsproblemen bij kinderen }\end{array}$ & $\begin{array}{l}\text { A1 (Groh et al., } \\
\text { 2012; Fearon et al., } \\
\text { 2010) }\end{array}$ \\
\hline 2 & $\begin{array}{l}\text { Het is aannemelijk dat vijandig opvoedgedrag samenhangt met } \\
\text { internaliserende en externaliserende gedragsproblemen bij het kind }\end{array}$ & $\begin{array}{l}\text { A2 (Cabaj et al., } \\
\text { 2014; Ezpeleta et al. } \\
\text { 2008; Velders et al., } \\
\text { 2011) }\end{array}$ \\
\hline 2 & $\begin{array}{l}\text { Het is aannemelijk dat streng straffen door ouders samenhangt met } \\
\text { externaliserende en internaliserende problemen bij kinderen }\end{array}$ & $\begin{array}{l}\text { A2 (Bayer et al, } \\
\text { 2011; Rijlaarsdam et } \\
\text { al, 2013) }\end{array}$ \\
\hline 2 & $\begin{array}{l}\text { Het is aannemelijk dat overbescherming door de ouders samenhangt met } \\
\text { een verhoogd risico op internaliserende problemen bij het kind }\end{array}$ & $\begin{array}{l}\text { A2 (Bayer et al., } \\
\text { 2011; C (Gere et al, } \\
\text { 2012) }\end{array}$ \\
\hline 2 & $\begin{array}{l}\text { Het is aannemelijk dat de een lage mate van zelfvertrouwen in de eigen } \\
\text { opvoedcompetenties samenhangt met internaliserende en externaliserende } \\
\text { gedragsproblemen bij kinderen }\end{array}$ & $\begin{array}{l}\text { A2 (Cabaj et al, } \\
\text { 2014; Weaver et al., } \\
\text { 2008) }\end{array}$ \\
\hline
\end{tabular}

\section{Risicofactoren mesoniveau}

\section{Gezinssituatie}

\begin{tabular}{|c|c|c|}
\hline Niveau & Conclusie & Literatuur \\
\hline 2 & $\begin{array}{l}\text { Het is waarschijnlijk dat kinderen uit een éénoudergezin vaker } \\
\text { probleemgedrag en emotionele problemen ontwikkelen dan hun } \\
\text { leeftijdsgenootjes in tweeoudergezinnen }\end{array}$ & $\begin{array}{l}\text { A2 (Ezpeleta et al., } \\
2008) \\
\text { C (Bot et al., 2011) }\end{array}$ \\
\hline
\end{tabular}




\section{Buurt}

\begin{tabular}{|l|l|l} 
Niveau & Conclusie & Literatuur \\
\hline 2 & $\begin{array}{l}\text { Het is waarschijnlijk dat kinderen uit achtergestelde gebieden vaker } \\
\text { psychosociale problemen hebben. }\end{array}$ & $\begin{array}{l}\text { A2 (Reijneveld et } \\
\text { al., 2010) } \\
\text { C (Reijneveld et al., } \\
2005)\end{array}$ \\
\hline
\end{tabular}

\section{Risicofactoren macroniveau}

\section{Sociaal Economische Status}

\begin{tabular}{|c|c|c|}
\hline Niveau & Conclusie & Literatuur \\
\hline 2 & $\begin{array}{l}\text { Het is aangetoond dat kinderen die opgroeien in een gezin met lage } \\
\text { sociaaleconomische status (ouders hebben laag inkomen, zijn werkloos, } \\
\text { of doen ongeschoold werk) meer internaliserende problemen hebben }\end{array}$ & $\begin{array}{l}\text { A2 (Rijlaarsdam et } \\
\text { al,. 2013; Ashford et } \\
\text { al., 2008b) }\end{array}$ \\
\hline 2 & $\begin{array}{l}\text { Het is waarschijnlijk dat kinderen die opgroeien in een gezin met lage } \\
\text { sociaaleconomische status (= ouders hebben laag inkomen) meer } \\
\text { externalizerende problemen hebben }\end{array}$ & $\begin{array}{l}\text { A2 (Rijlaarsdam et } \\
\text { al., 2013) }\end{array}$ \\
\hline 3 & $\begin{array}{l}\text { Er zijn aanwijzingen dat kinderen die opgroeien in een gezin met lage } \\
\text { sociaaleconomische status (= laag opleidingsniveau ouders) meer } \\
\text { psychosociale problemen hebben }\end{array}$ & $\begin{array}{l}\text { C (Bot et al., 2011; } \\
\text { Taggart et al., 2010) }\end{array}$ \\
\hline
\end{tabular}

\section{Arbeidsmigranten en vluchtelingen}

\begin{tabular}{|l|l|l|}
\hline 3 & $\begin{array}{l}\text { Conclusie } \\
\text { Er zijn aanwijzingen dat kinderen van niet-Nederlandse komaf meer } \\
\text { internaliserende problemen hebben }\end{array}$ & $\begin{array}{l}\text { Literatuur } \\
\text { C (Crone et al., } \\
2010 ; \text { Janssen et al., } \\
2004 ; \text { Reijneveld et } \\
\text { al., 2005; Darwish et } \\
\text { al., 2003) }\end{array}$ \\
C (Crone et al., \\
$2010)$
\end{tabular}


Beschermend factoren microniveau: kind

\begin{tabular}{|c|c|c|}
\hline Niveau & Conclusie & Literatuur \\
\hline 2 & $\begin{array}{l}\text { Het is aannemelijk dat niet-verbale, cognitieve vaardigheden van het } \\
\text { kind beschermen tegen gedrags- en emotionele problemen bij de } \\
\text { aanwezigheid van proximale familierisico's }\end{array}$ & $\begin{array}{l}\text { A2 (Flouri et al., } \\
\text { 2010) }\end{array}$ \\
\hline 2 & $\begin{array}{l}\text { Het is aannemelijk dat een hoog IQ van het kind beschermen tegen het } \\
\text { ontwikkelen van psychopathologie, wanneer moeder een depressie heeft }\end{array}$ & $\begin{array}{l}\text { A2 (Pargas et al., } \\
\text { 2010) }\end{array}$ \\
\hline 2 & $\begin{array}{l}\text { Het is aannemelijk dat veel zelfvertrouwen en gezond sociaal } \\
\text { functioneren beschermt tegen het ontwikkelen van psychopathologie }\end{array}$ & $\begin{array}{l}\text { A2 (Pargas et al., } \\
\text { 2010) }\end{array}$ \\
\hline 3 & $\begin{array}{l}\text { Er is een aanwijzing dat veel zelfvertrouwen beschermt tegen delinquent } \\
\text { gedrag }\end{array}$ & $\begin{array}{l}\text { C (Kabiru et al., } \\
\text { 2014) }\end{array}$ \\
\hline 3 & $\begin{array}{l}\text { Er is een aanwijzing dat een positieve etnische identiteit, en hoger } \\
\text { gevoel van eigenwaarde zijn een beschermende factor voor depressie en } \\
\text { angst bij allochtone jongeren }\end{array}$ & $\begin{array}{l}\text { C (Garcia Reid et al., } \\
\text { 2013) }\end{array}$ \\
\hline
\end{tabular}

\section{Beschermende factoren microniveau: ouder}

\begin{tabular}{|l|l|l|}
\hline Niveau & $\begin{array}{l}\text { Conclusie } \\
2\end{array}$ & $\begin{array}{l}\text { Het is aannemelijk dat een warme opvoedstijl van moeders een } \\
\text { beschermende factor is tegen het ontwikkelen van emotionele- en } \\
\text { gedragsproblemen, wanneer het kind gepest wordt }\end{array}$ \\
$\begin{array}{l}\text { Het is aannemelijk dat een goede relatie met de ouders een } \\
\text { beschermende factor is tegen het ontwikkelen van externalizerende } \\
\text { problemen, wanneer het kind negatieve levensgebeurtenissen heeft } \\
\text { meegemaakt }\end{array}$ & $\begin{array}{l}\text { A2 (Bowes et al., } \\
\text { Er is een aanwijzing dat kinderen van moeders die thuis meer } \\
\text { leeractiviteiten ondernemen, minder externalizerende problemen } \\
\text { hebben } \\
\text { Er is een aanwijzing dat sensitief opvoedgedrag van moeders een } \\
\text { beschermende factor is tegen het ontwikkelen van sociaal-emotionele } \\
\text { problemen, bij aanwezigheid van hoge ouderlijke stress }\end{array}$ & $\begin{array}{l}\text { A2 (Oliva et al., } \\
2009)\end{array}$ \\
\hline
\end{tabular}

\section{Beschermende factoren mesoniveau}

\begin{tabular}{|c|c|c|}
\hline Niveau & Conclusie & Literatuur \\
\hline 3 & $\begin{array}{l}\text { Er is een aanwijzing dat ervaren sociale steun beschermt tegen de } \\
\text { ontwikkeling van probleemgedrag bij kinderen }\end{array}$ & $\begin{array}{l}\text { C (Asscher et al, } \\
2005)\end{array}$ \\
\hline 3 & $\begin{array}{l}\text { Er is een aanwijzing dat sociale steun fungeert als buffer tussen stress } \\
\text { voor de moeder, inadequaat opvoedgedrag en de ontwikkeling van } \\
\text { internaliserend en externaliserend probleemgedrag bij het kind }\end{array}$ & $\begin{array}{l}\text { C (Heberle et al., } \\
\text { 2014) }\end{array}$ \\
\hline 3 & $\begin{array}{l}\text { Er is een aanwijzing dat sociale steun de betrokkenheid van oma's een } \\
\text { beschermende factor is tegen het ontwikkelen van externalizerende } \\
\text { problemen, wanneer moeders een strenge opvoedstijl hanteren }\end{array}$ & $\begin{array}{l}\text { C (Barnett et al., } \\
2010)\end{array}$ \\
\hline
\end{tabular}




\subsection{Risicofactoren}

Hieronder bespreken we alleen die risicofactoren, waarbij de samenhang met het ontstaan of in stand houden van psychosociale problemen bij kinderen in empirisch onderzoek is vastgesteld. Waarschijnlijk zijn méér risicofactoren van belang bij het ontstaan van psychosociale problemen, dan hier in de richtlijn vermeld worden, zoals hoogbegaafdheid bij het kind, maar van dergelijke factoren is nog onvoldoende onderzoek gedaan, waardoor bewijsmateriaal zwak of afwezig is.

Specifiek voor de JGZ is de aandacht voor gezond opgroeien en opvoeden en het voorkomen van risico's en psychosociale problemen. Om die reden is het van belang om naast risicofactoren ook altijd de beschermende factoren in een gezin goed in kaart te brengen. In paragraaf 4.2 komen de beschermende factoren aan bod.

\subsubsection{Risicofactoren op microniveau: kind}

\section{Matige of ernstige prematuriteit}

Kinderen die te vroeg en/of te licht geboren worden hebben een hogere kans op psychosociale problemen dan kinderen die niet te vroeg of met een normaal gewicht geboren worden (van Baar, et al., 2009; Reijneveld et al., 2006; Arpi \& Ferrari, 2013; Potijk et al., 2012; Talge et al., 2010). In de studie van Potijk et al. (2012) bleek dat kinderen die na 32-36 weken zwangerschap geboren werden, op de leeftijd van 4 jaar bijna 2 keer zoveel kans hebben om psychosociale problemen te ontwikkelen. De studie van Arpi en Ferrari (2013) laat zien dat zowel matig prematuren (zwangerschapsduur tussen 32 en 37 weken) als de ernstig prematuur geboren kinderen (zwangerschap korter dan 32 weken of gewicht < 1500 gram) meer psychosociale problemen hebben in vergelijking met op tijd geboren kinderen. De hoge mate van stress waarmee prematuur geboren kinderen te maken krijgen, leidt ertoe dat ze sneller geprikkeld en negatief reageren op hun omgeving en dat ze minder goed hun emoties leren te reguleren, in vergelijking met voldragen kinderen (Wu et al., 2016).

\section{Temperament kind}

De term 'temperament' verwijst naar een aangeboren gedragsstijl die stabiel is over de levensloop en waarbij kinderen verschillen naar de mate van intensiteit van hun emotionele reacties, reactie op nieuwe stimuli, aandachtsspanne, sociabiliteit, activiteitsniveau en aanpassingsvermogen (Goldsmith et al., 1987). Een 'moeilijk' temperament wordt gedefinieerd als geremd, prikkelbaar, en minder sociaal. Een geremd, prikkelbaar temperament op jonge leeftijd hangt samen met psychiatrische symptomen in de adolescentie zoals angststoornissen (Teerikangas et al., 1998; Caspi et al., 1995). Ook kinderen die als peuter de neiging hebben om erg teruggetrokken en geremd te reageren op onbekende situaties en personen hebben een verhoogd risico op emotionele problemen als ze in de pubertijd komen (Teerikangas et al., 1998; Schwarts Snidman \& Kagan, 1999). Terwijl kinderen met een lage aandachtspanne in de kleuterleeftijd als tiener vaker externalizerende problemen hebben (Caspi et al., 1995). Dat deze gedragsstijlen een voorloper zijn van hetzelfde gedrag in een meer problematische vorm op latere leeftijd is niet verwonderlijk. Het onderzoek van Berdan et al. (2008) en Biederman et al (2011) laat zien dat kinderen met een extrovert, ongeremd temperament vaker hyperactiviteit en agressie laten zien.

\section{Leeftijd kind}


De rol van leeftijd in het voorkomen van psychosociale problemen is niet eenduidig. Afgaand op psychosociale problemen die door JGZ professionals gesignaleerd worden bij kinderen tot 12 jaar, is de prevalentie op de leeftijd van 14 maanden laag (vooral bij meisjes: $8 \%$ heeft psychosociale problemen). Op deze leeftijd hebben kinderen volgens de JGZ vooral problemen met slapen, spraak/ taal of eten.

Tabel 1: Percentage jongens en meisjes van 0 tot en met 12 jaar met psychosociale problemen volgens de jeugdgezondheidszorg (Bron: Zeijl et al., 2005).

\begin{tabular}{|l|cc|cc|cc|cc|}
\hline & \multicolumn{3}{|c}{ 14 maanden } & \multicolumn{2}{c}{ 3 jaar } & \multicolumn{2}{c|}{ 5-6 jaar } & \multicolumn{2}{c|}{ 8-12 jaar } \\
& Jongens & Meisjes & Jongens & Meisjes & Jongens & Meisjes & Jongens & Meisjes \\
& & & & & & & & \\
& $\%$ & $\%$ & $\%$ & $\%$ & $\%$ & $\% s$ & $\%$ & $\%$ \\
\hline Geen & 87 & 92 & 76 & 87 & 67 & 78 & 77 & 82 \\
Licht & 9 & 5 & 13 & 6 & 17 & 13 & 10 & 10 \\
Matig & 2 & 3 & 10 & 5 & 13 & 7 & 10 & 7 \\
Ernstig & 1 & 1 & 1 & 2 & 3 & 1 & 3 & 1 \\
\hline
\end{tabular}

Op de leeftijd van 5 en 6 jaar wordt een piek gesignaleerd, vooral bij de jongens (33\% van de jongens heeft problemen, tegen $22 \%$ van de meisjes). In leeftijd van 8 tot 12 jaar zakt de prevalentie van psychosociale problemen weer af (zie Tabel 1) (Zeijl et al., 2005). Volgens ouders is de prevalentie van psychosociale problemen bij 0-12 jarigen 4-6\%, dit is vastgesteld op basis van hun oordeel op de Child Behavior Checklist vragenlijst (Zeijl et al., 2005, zie Tabel 2), of iets hoger volgens meer recentere cijfers $10 \%$ (8-12 jarigen)(Bot et al., 2011). Reijneveld en collega's rapporteren dat $8 \%$ van de Nederlandse basisschoolkinderen een externaliserend probleem en $12 \%$ een internaliserend probleem heeft (Reijneveld et al., 2006).

Tabel 2: Percentage jongens en meisjes van 0 tot en met 12 jaar met psychosociale problemen volgens ouders (Bron: Zeijl et al., 2005).

\begin{tabular}{|c|c|c|c|c|c|c|c|c|}
\hline & \multicolumn{2}{|c|}{14 maanden } & \multicolumn{2}{|c|}{3 jaar } & \multicolumn{2}{|c|}{ 5-6 jaar } & \multicolumn{2}{|c|}{ 8-12 jaar } \\
\hline & $\begin{array}{c}\text { Jongens } \\
\%\end{array}$ & $\begin{array}{c}\text { Meisjes } \\
\%\end{array}$ & $\begin{array}{c}\text { Jongens } \\
\%\end{array}$ & $\begin{array}{c}\text { Meisjes } \\
\%\end{array}$ & $\begin{array}{c}\text { Jongens } \\
\%\end{array}$ & $\begin{array}{c}\text { Meisjes } \\
\%\end{array}$ & $\begin{array}{c}\text { Jongens } \\
\%\end{array}$ & $\begin{array}{c}\text { Meisjes } \\
\%\end{array}$ \\
\hline Totaal score & 5 & 2 & 8 & 4 & 8 & 3 & 7 & 5 \\
\hline Internaliserend & 7 & 4 & 8 & 8 & 10 & 7 & 9 & 7 \\
\hline Externaliserend & 3 & 4 & 9 & 4 & 4 & 4 & 6 & 6 \\
\hline
\end{tabular}

De prevalentie van psychosociale problemen bij adolescenten (12-16 jarigen, zelf-rapportage) is 15\% (Dorsselaer, et al., 2010). Bij adolescenten (13-16 jarigen) varieert de prevalentie van internaliserende problemen van 17-19\%, en de prevalentie van externaliserende problematiek van 14-18\%, afhankelijk van de leeftijdsgroep (van Stein et al., 2014).

\section{Geslacht kind}

Er zijn aanwijzingen dat externaliserende gedragsproblemen vaker voorkomen bij jongens (Zahn-Waxler, Shirtcliff, \& Marceau, 2008), terwijl meisjes meer internaliserende problemen laten zien, met name in de adolescentie (van Dorsselaer et al., 2010; van Steijn et al., 2014). Al vanaf de leeftijd van vier jaar vertonen jongens significant meer externaliserend probleemgedrag dan meisjes (Kerr, Lopez, Olson, \& Sameroff, 2004). Dit sekseverschil blijkt stabiel te zijn over de kleutertijd heen. Dus zowel op de basisschool als in de adolescentie komen druk, hyperactief en 
grensoverschrijdend gedrag vaker voor bij jongens, terwijl meisjes meer piekeren en vaker last hebben van sombere gevoelens.

\section{Kinderen met een chronische aandoening of licht verstandelijke beperking}

Er zijn aanwijzingen dat jeugdigen met een chronische aandoening, zoals astma, een verhoogd risico hebben op psychosociale problemen (Bayer et al.; 2011; Bot et al., 2011; Chen, 2014). Het onderzoek van Zeijl (2005) laat zien dat kinderen in de leeftijd van 3-12 jaar met een lichamelijk ziekte vaker dan andere kinderen psychosociale problemen hebben, het gaat hierbij dan vooral om internaliserende problematiek. Datzelfde geldt voor een cognitieve beperking. Bij de LVB groep (Licht Verstandelijke Beperking; IQ-score van 50 tot 85 en een beperkt sociaal aanpassingsvermogen) worden zeer hoge prevalenties van psychosociale problemen vastgesteld: maar liefst 61\% van de 6-12 jarigen met een verstandelijke beperking hadden een verhoogde score op de Strenghts and Difficulties Questionnaire (SDQ) (Kaptein et al., 2008).

Jongeren die te kampen hebben met zowel LVB als een chronische aandoening, hebben veel vaker psychosociale problemen: bijna de helft van deze jongeren (45\%) had psychosociale problemen. Bij LVB jongeren die geen chronische ziekte hebben, lag de prevalentie van psychosociale problemen op 17\% (Oeseburg et al., 2010).

\subsubsection{Risicofactoren op microniveau: ouder}

\section{Chronische somatische aandoening bij de ouder}

Onderzoek van Sieh en collega's (Sieh, Meijer, Oort, Visser, Meilly, \& Van er Leij, 2010; Sieh, Visser-Meily, \& Meijer, 2013) heeft de impact van een chronisch somatische aandoening bij de ouder op het kind inzichtelijk gemaakt: bij deze groep werd meer internaliserend en externaliserend probleemgedrag gerapporteerd in vergelijking met kinderen van gezonde ouders (Sieh et al, 2010). Door de langdurige belasting van de zorg voor en zorgen om de ouder, ervaren adolescenten meer internaliserende problemen zoals angsten, somberheid, teruggetrokken gedrag, en gevoelens van machteloosheid (Sieh et al., 2013). Er worden ook zwakkere schoolprestaties gerapporteerd bij basisschoolkinderen en meisjes in de tienerleeftijd die opgroeien in een gezin waarbij één van de ouders lijdt aan kanker (Visser et al, 2004).

\section{Psychische gesteldheid van de ouders en verslavingsproblematiek}

Psychische of psychiatrische problemen die voorkomen bij één van de ouders hebben vrijwel altijd grote gevolgen voor de ontwikkeling van het kind (Beck, 1999; Goodman et al, 2001; Cabaj, McDonald, \& Tough, 2014), in de zin dat de kans heel groot is dat het kind zelf psychosociale problemen ontwikkelt. Deze kinderen worden ook wel aangeduid als KOPP (Kinderen van Ouders met Psychische Problemen). Psychosociale problemen bij deze kinderen kunnen ontstaan door erfelijkheid of door minder adequaat opvoedgedrag ten gevolge van de problemen bij de ouder (Ashford, et al. 2008; Hipwell et al., 2000; Flouri et al., 2013). Of deze kinderen problemen ontwikkelen, is afhankelijk van de verschillende kind-, ouder- en omgevingsfactoren, zoals de aanwezigheid van sociale steun voor het gezin, de kwaliteit van de gehechtheidsrelatie tussen ouder en kind; en de mate waarin de ouder in staat is om adequaat opvoedgedrag te laten zien (Romijn, De Graaf, \& De Jonge, 2010).

Depressie bij de moeder hangt samen met een hogere mate van internaliserende problemen en externaliserende problemen bij het kind (Goodman et al, 2011; Biederman et al, 2001). Ook moeders die veel angst ervaren en overbezorgd zijn, hebben vaker angstige kinderen (Bayer et al. , 2011). Pawlby et al (2011) toonden aan dat een depressie van de moeder (voordat het kind 
geboren werd) de kans op mishandeling van het kind vier keer vergrootte; en de combinatie van zowel een depressieve moeder en het meemaken van mishandeling vergroot de kans op psychopathologie bij het kind maar liefst 12 keer.

Een post-partumdepressie van de moeder heeft negatieve gevolgen voor de ontwikkeling van het kind: het kind heeft een verhoogd risico op verstoringen in de mentale ontwikkeling, gebrekkige zelfregulatie, een laag zelfvertrouwen en langdurige gedragsproblematiek (Halligan et al., 2012; Beck, 1999). Tenslotte zijn er samenhangen gevonden tussen een postpartum depressie en een onveilige gehechtheidsrelatie tussen moeder en kind (Hipwell e.a., 2000; Cummings \& Davies, 1994).

Psychopathologie bij de vader hangt samen met het voorkomen van psychosociale problemen bij het kind. Depressie bij de vaders hangt samen met een hogere mate van zowel internaliserende, externaliserende en sociale problemen bij het kind (Herbert et al., 2013). ADHD (Attention Deficit Hyperactivity Disorder) bij vaders bleek samen te hangen met externaliserend probleemgedrag bij het kind (Herbert et al., 2013).

Kinderen van ouders met psychische en/of verslavingsproblemen hebben in vergelijking met kinderen die opgroeien bij psychisch gezonde ouders drie tot dertien keer zo groot risico om zelf ook psychische problemen en/of verslavingsproblematiek te ontwikkelen (Beck 1999; Clark, et al., 2004; Cuijpers, et al., 1999; Goodman et al, 2011; McLaughlin et al., 2012)

\section{Mishandeling van de moeder tijdens de jeugd}

Kinderen van moeders die in hun jeugd het slachtoffer zijn geweest van emotionele, fysieke of seksuele mishandeling vertonen meer externaliserend gedrag in vergelijking met een vergelijkingsgroep, zelfs na controle voor verschillende achtergrondkenmerken (leeftijd moeder, opleidingsniveau, samenlevingsvorm, partnergeweld en geslacht kind) (Myhre, Dyb, Wentzel-Larsen, Grøgaard \& Thoresen, 2014). Vrouwen die het slachtoffer zijn geweest in hun jeugd van kindermishandeling, in combinatie met een depressie tijdens de zwangerschap, hebben een verhoogd risico op mishandeling en verwaarlozing van hun kinderen. Hun kinderen hebben eveneens een verhoogd risico op het ontwikkelen van psychopathologie (Plant, Barker, Waters, Pawlby, \& Pariante, 2013).

\section{Middelengebruik tijdens de zwangerschap}

Er zijn verbanden gevonden tussen actief roken tijdens de zwangerschap en de prevalentie van psychosociale problemen bij kinderen; waarbij de samenhang meestal complex is. De studie van Motlagh et al. (2010) laat zien dat roken in combinatie met veel psychosociale stress voor de moeder samengaat met de diagnose ADHD bij hun kinderen die varieerden in de leeftijd van 7 tot 18 jaar. Ook Monshouwer et al. (2011) constateerde een relatie tussen roken tijdens de zwangerschap en hyperactief gedrag in de adolescentie, zelfs na correctie van Sociaal Economische Status (SES) en leeftijd moeder. Kinderen van moeders die roken tijdens de zwangerschap hebben 1,5-1,8 meer kans op psychosociale problemen op de leeftijd van 14-16 jaar (Monshouwer et al., 2011). Ashford et al (2008a) constateerde een samenhang tussen roken tijdens de zwangerschap en internaliserend als externaliserend probleemgedrag bij het kind. De studie van Alvik et al. (2013) toonde aan dat alcoholgebruik tijdens de zwangerschap (1 tot 3 glazen per week) samengaat met psychosociale problemen bij het kind op de leeftijd van 5 jaar. De ernst van de gevolgen neemt toe naarmate de zwangere meer alcohol gebruikt. 


\section{Ouders met een (licht) verstandelijke beperking (LVB)}

Ouders met (licht) verstandelijke beperking (LVB) hebben - naast een laag IQ en een beperkt sociaal aanpassingsvermogen - veelal te maken met beperkte sociale steun, een lage SES en armoede, of psychopathologie (Feldman, 2002; Zoon \& Foolen, 2014). Deze beperkingen en problemen kunnen van invloed zijn op het opvoedgedrag. Er is geen wetenschappelijk onderzoek gevonden naar de relatie tussen LVB bij de ouder(s) en psychosociale problemen bij het kind. De werkgroep vindt LVB een belangrijke risicofactor, waardoor deze factor toch is opgenomen in de richtlijn. Er is wel aangetoond dat kinderen van ouders met LVB een groter risico op verwaarlozing en mishandeling hebben, wat mogelijk psychosociale problemen als gevolg kan hebben (Coren et al., 2011). Bij de helft van de ouders met LVB zijn signalen van verwaarlozing of mishandeling vastgesteld door hulpverleners, en is er hulp/ondersteuning van Jeugdbescherming in het gezin (Willems et al., 2007; Zoon \& Foolen, 2014).

De Handreiking voor ondersteuning van ouders met een verstandelijke beperking (De Jong, Stremmelaar, \& Looij, 2014) stelt dat ouders met LVB hun 'beperking' goed kunnen verbergen. In deze handreiking is een lijst met aandachtspunten opgenomen voor professionals hoe ouders met LVB herkend kunnen worden. Voor een JGZ-professional is het van belang om alert te zijn op LVB en bij een vermoeden het gesprek met de ouders aan te gaan. Mocht inderdaad sprake zijn van LVB bij de ouder(s), dan is het wenselijk om het sociale netwerk van het gezin in kaart te brengen en de opvoeding en ontwikkeling van het kind te volgen.

\subsubsection{Risicofactoren op microniveau: ouder-kind interactie}

\section{Opvoedstijlen en gehechtheidsrelatie}

In gezinnen waarin de interactie tussen ouders en kind minder sensitief of minder warm verloopt, komen psychosociale problemen vaker voor bij het kind. Meer specifiek de volgende bevindingen wat betreft die ouder-kind interactie zijn gevonden:

De gehechtheidsrelatie tussen ouder en kind is een belangrijke determinant van psychosociale problemen bij het kind. In twee meta-analyses zijn de volgende samenhangen gevonden:

o Internaliserende problemen komen vaker voor bij kinderen en jongeren met een onveilig- vermijdende gehechtheidsrelatie (Groh et al., 2012).

- Externaliserende problemen komen vaker voor bij kinderen met een gedesorganiseerde gehechtheidsrelatie (Fearon et al., 2010). In een gedesorganiseerde gehechtheidsrelatie is de ouder zowel een bron van steun als een bron van angst voor een kind. Dat wil zeggen: soms stelt de ouder het kind gerust, maar er zijn ook momenten dat de ouder angst oproept bij het kind doordat de ouder bijvoorbeeld op bepaalde momenten volledig in zichzelf gekeerd is ten gevolge van trauma's of een depressie. Dit onoplosbare dilemma (de ouder nodig hebben voor steun en tegelijk bang zijn voor de ouder) levert zoveel stress op voor het kind, dat het geen strategie ontwikkelt om de eigen emoties te reguleren. Bij boosheid, verdriet of angst uiten kinderen met een gedesorganiseerde gehechtheidsrelatie deze emoties vaker in externaliserend gedrag (Fearon et al., 2010).

Vijandig, afwijzend opvoedgedrag hangt samen met het voorkomen van meer internaliserende en externaliserende problemen bij kinderen (Cabaj et al., 2014; Ezpeleta et al. 2008; Velders et al, 2011). 
- $\quad$ Ouders die streng zijn in het stellen en handhaven van de regels, hebben vaker kinderen met internaliserende en externaliserende problemen (Bayer et al., 2011; Rijlaarsdam et al.2013).

Overbescherming door de moeder hangt samen met meer internaliserende symptomen bij het kind (Bayer et al., 2011; Gere et al., 2012).

Een lage mate van vertrouwen in de eigen opvoedcompetenties hangt samen met probleemgedrag bij kinderen (Weaver et al., 2008).

\subsubsection{Risicofactoren op meso-niveau}

\section{Gezinssituatie}

- $\quad$ Kinderen uit een éénoudergezin ontwikkelen vaker probleemgedrag en emotionele problemen dan hun leeftijdsgenootjes in tweeoudergezinnen (Bot et al., 2011; Ezpeleta et al., 2008). Een verklaring voor het negatieve effect van éénoudergezinnen kan zijn het ontbreken van de steunende, tweede ouder; of het voorkomen van conflicten met de ex-partner.

- $\quad$ Kinderen uit gezinnen waarin relatief veel ingrijpende gebeurtenissen zoals het overlijden van een familielid, een ziekenhuisopname of echtscheiding voordoen, hebben een verhoogde kans op emotionele en gedragsproblemen (Harland et al., 2002). Ingrijpende levensgebeurtenissen kunnen het probleemgedrag ook in stand houden (Timmermans et al., 2010).

\section{De buurt}

Kinderen die in een achtergesteld gebied wonen, of dat nu in een grote stad is of op het platteland, hebben vaker psychosociale problemen in vergelijking met landelijke prevalentie-cijfers (Reijneveld et al., 2005; Reijneveld et al., 2010). In beide studies werd een 'achtergesteld gebied' gemeten als een wijk waarin de werkloosheid relatief hoog was en het gemiddeld inkomen en opleidingsniveau het laagst (gebaseerd op cijfers van de Sociaal Cultureel Planbureau). Vooral externaliserende problemen komen vaker voor bij jeugdigen die in een achtergestelde omgeving opgroeien.

\subsubsection{Risicofactoren op macroniveau}

\section{Sociaal Economische Status (SES)}

Kinderen en jongeren uit gezinnen met een lage Sociaal Economische Status (SES) hebben vaker emotionele en gedragsproblemen dan leeftijdsgenoten uit hogere SES klassen (Rijlaarsdam et al.,2013; Bot et al, 2011; Ashford et al., 2008b; Taggart et al., 2010). Kinderen met een lage SES hebben bijna twee keer zoveel kans om een psychosociaal probleem te ontwikkelen (Bot et al., 2011). In deze studies wordt een lage SES opgevat als een laag opleidingsniveau van de ouder(s), al dan niet in combinatie met een lage inkomen (dwz: ouders hebben een laag inkomen doordat ze werkloos zijn of ongeschoold werk verrichten). Volgens Rijlaarsdam et al. (2013) verloopt de samenhang tussen lage SES en psychosociale problemen via depressie van de moeder, ouderlijke stress en harde, inadequate discipline.

Een lage SES gaat samen met meer internaliserend probleemgedrag (zoals angst, depressie, en sociale teruggetrokkenheid) en meer externaliserend probleemgedrag (zoals ongehoorzaamheid, agressie, en hyperactiviteit). Vanwege zorgen over financiën, huisvesting of werk hanteerden de ouders een minder ondersteunende opvoedstijl en bovendien bleek dat gezinnen in armoede 
relatief vaak stressvolle levensgebeurtenissen meemaken. Deze aspecten vergroten de kans dat een kind psychosociale problemen ontwikkelt.

Kortom: er is veel bewijs voor het verband tussen lage SES en het voorkomen van psychosociale problemen, maar hoe dit verband precies verloopt is niet duidelijk. Een mogelijke verklaring is dat het negatieve effect van een lage SES resulteert in een hoog stressniveau voor de ouder en/of negatief opvoedgedrag en op deze wijze doorgegeven wordt aan het kind.

\section{Allochtone achtergrond: arbeidsmigranten en vluchtelingen}

Er zijn verschillende groepen allochtone kinderen in Nederland. Een grote groep bestaat uit kinderen die al geruime tijd in Nederland verblijven en waarbij de ouders in de vorige eeuw vanuit Marokko, Turkije, Suriname of de Nederlandse Antillen (Gelauff-Hanzon,1994) naar Nederland zijn gekomen: de arbeidsmigranten. Daarnaast zijn er arbeidsmigranten afkomstig uit Midden- en Oost-Europa, waarbij de grootste groep afkomstig is uit Polen. Vanaf de jaren tachtig van de vorige eeuw maken vluchtelingenkinderen een steeds groter deel uit van de Nederlandse populatie. Dit zijn kinderen van asielzoekers. Herkomstlanden zijn onder andere: Irak, Iran, Somalië, Afghanistan en Syrië.

Psychosociale problemen (gerapporteerd door ouders of kinderen zelf) komen vaker voor bij kinderen van arbeidsmigranten in vergelijking met autochtone kinderen (Crone et al., 2010; Janssen et al., 2004; Reijneveld et al., 2005; Darwish et a., 2003). Er zijn aanwijzingen dat kinderen van arbeidsmigranten een 2-4 keer grotere kans hebben om psychosociale problemen te ontwikkelen dan autochtone kinderen (Crone et al., 2010). Deze verschillen zijn vooral zichtbaar voor psychosociale problemen in het algemeen en voor internaliserende problematiek (Crone et al 2010; Janssen et al., 2004; Reijneveld et al., 2005).

Vluchtelingenkinderen vormen een zeer kwetsbare groep, vooral de eerste jaren na aankomst in Nederland. Het aantal keren dat kinderen en gezinnen 'verhuizen' naar verschillende opvangcentra blijkt van invloed: Vluchtelingenkinderen die meer dan één keer in een jaar verhuizen hebben 2,7 keer vaker psychosociale problemen (Goosen et al., 2014). Dit risico was groter bij kinderen die geweld hebben meegemaakt en bij kinderen waarvan de moeder gediagnosticeerd is met post-traumatische stress stoornis (PTSS) of depressie (Goosen et al., 2014). Verder is de mate waarin het kind van asielzoekers blootgesteld is geweest aan geweld een bepalende factor: heeft het kind veel geweld meegemaakt, dan heeft het kind vaker psychische problemen (Fazel et al., 2012).

\subsection{Beschermende factoren}

Hieronder bespreken we de beschermende factoren, waarvan in onderzoek is vastgesteld dat ze de negatieve invloed van risicofactoren op de psychosociale ontwikkeling van kinderen daadwerkelijk inperken.

\subsubsection{Beschermende factoren op microniveau: kind}

\section{Intelligentie en zelfvertrouwen van het kind}

Intelligentie en zelfvertrouwen zijn beschermende factoren in het kind zelf (Flouri et al., 2010; Pargas et al. 2010). Kinderen die intelligent zijn, blijken doorgaans over een grotere veerkracht ('resilience') te beschikken, en kunnen beter problemen oplossen, dan hun minder intelligente leeftijdsgenoten. Ze blijken vaak te beschikken over betere sociale vaardigheden en zijn vaardiger in het reguleren van hun emoties. Zelfvertrouwen van het kind beschermt tegen het ontwikkelen 
van psychopathologie (Pargas et al, 2010). In de studie van Garcia Reid bleek dat zelfvertrouwen en een sterke etnische identiteit beschermt tegen depressie en angst bij allochtone jongeren die in moeilijke omstandigheden opgroeien (Garcia Reid et al, 2013).

\subsubsection{Beschermende factoren op microniveau: ouder kind interactie}

\section{Warme sensitieve opvoedstijl en goede band met ouders}

Een warme, sensitieve opvoedstijl is een beschermende factor: verschillende studies hebben aangetoond dat moederlijke warmte en responsiviteit als buffer kan fungeren bij de aanwezigheid van risicofactoren. Een warme opvoedstijl van moeders beschermt tegen emotionele- en gedragsproblemen wanneer het kind gepest wordt (Bowes et al, 2010), of tegen sociaal-emotionele problemen ten gevolge van hoge ouderlijke stress (Whittaker, et al. 2011). Een goede band met de ouders beschermt tegen het ontwikkelen van internaliserende en externaliserende problemen van het kind, wanneer zich ingrijpende levensgebeurtenissen (zoals het verlies van een ouder of een misdrijf) hebben voorgedaan (Oliva et al., 2009).

\subsubsection{Beschermende factoren op meso-niveau}

\section{Sociale steun vanuit informele netwerk}

Er zijn aanwijzingen dat ouders die sociale steun vanuit hun informele netwerk ervaren, beter kunnen omgaan met moeilijk of lastig gedrag van hun kinderen. Sociale steun maakt dat kinderen minder probleemgedrag ontwikkelen ten gevolge van aanwezige risicofactoren (Asscher et al., 2005). In de studie van Heberle et al (2014) fungeerde sociale steun van het informele sociale netwerk als buffer tussen stress voor de moeder, inadequaat opvoedgedrag en de ontwikkeling van internaliserend en externaliserend probleemgedrag van kinderen. Tenslotte bleek in de studie van Barnett et al. (2010) dat betrokkenheid van oma de samenhang tussen een strenge, hardhandige opvoeding door de ouders en externaliserende problemen bij kleuters van 3 en 4 jaar oud verlaagt.

\subsection{Overzicht van de risico- en beschermende factoren en sterkte van de verbanden}

Tabel 3 geeft de risico- en beschermende factoren schematisch weer. Leeftijd van het kind is niet opgenomen in de tabel, omdat de relatie met psychosociale problemen niet eenduidig is, de prevalenties verschillen per informatiebron (ouder, kind, en JGZ-professional). Psychosociale problemen komen niet vaker voor bij jongens of meisje, maar het verschilt wel per type probleem. Externaliserende problemen komen vaker voor bij jongens, terwijl meisjes in de adolescentie vaker internaliserende problemen rapporteren. Het is belangrijk om te realiseren dat sommige risicofactoren belangrijker zijn dan andere factoren. Hoe meer risicofactoren er voorkomen, des te grotere kans op een psychosociaal probleem bij het kind (zie Tabel 4).

Tabel 3: Samengevat risico- en beschermende factoren, cursief gedrukte risicofactoren hebben een lagere wetenschappelijke bewijslast

Bedreigend

Beschermend 


\begin{tabular}{|c|c|}
\hline \multicolumn{2}{|c|}{ KIND } \\
\hline 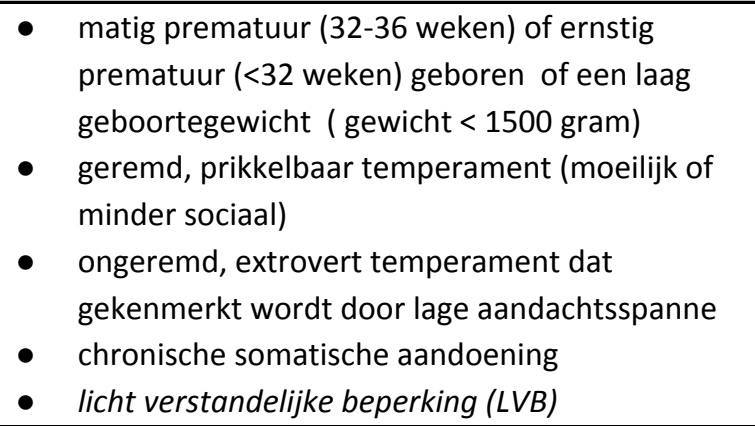 & $\begin{array}{ll}\text { - } & \text { intelligent kind } \\
\text { - } & \text { veel zelfvertrouwen bij het kind }\end{array}$ \\
\hline \multicolumn{2}{|c|}{ OUDER(S) } \\
\hline $\begin{array}{l}\text { - } \text { chronische somatische aandoening } \\
\text { - psychiatrische en/of verslavingsproblemen zoals } \\
\text { (postpartum)depressie bij moeder of } \\
\text { depressie/ADHD/ middelenstoornis bij vader } \\
\text { - moeder heeft in haar jeugd mishandeling } \\
\text { meegemaakt } \\
\text { - alcoholgebruik bij moeder (1 tot } 3 \text { glazen per } \\
\text { week) of actief roken van moeder tijdens de } \\
\text { zwangerschap } \\
\text { één van de volgende opvoedstijlen: vijandig, } \\
\text { afwijzend, gebruik makend van strenge straffen } \\
\text { of overbescherming } \\
\text { weinig vertrouwen in de eigen } \\
\text { opvoedcompetenties }\end{array}$ & $\begin{array}{l}\text { - warme, sensitieve opvoedstijl (zoals acceptatie } \\
\text { en responsiviteit) van moeder } \\
\text { - goede band tussen kind en ouders }\end{array}$ \\
\hline \multicolumn{2}{|c|}{ GEZIN EN OMGEVING } \\
\hline $\begin{array}{l}\text { - onveilig vermijdend of gedesorganiseerde } \\
\text { gehechtheidsrelatie tussen ouder en kind } \\
\text { - éénouder gezin } \\
\text { - ingrijpende gebeurtenissen zoals echtscheiding } \\
\text { - lage Sociaal Economische Status (SES, lage } \\
\text { opleiding en/of laag inkomen) } \\
\text { - achtergestelde woonomgeving (wijk met veel } \\
\text { werkeloosheid en laag inkomen en } \\
\text { opleidingsniveau) } \\
\text { - allochtone achtergrond (dwz: afkomstig uit } \\
\text { niet-geïndustrialiseerde landen zoals Suriname } \\
\text { en Antillen en economische immigranten (o.a. } \\
\text { Polen, Turken en Marokkanen) } \\
\text { - een gevlucht of een asielzoekersgezin dat vaker } \\
\text { dan } 1 \text { keer in een jaar verhuist; of een gezin } \\
\text { waarin het kind blootgesteld is geweest aan } \\
\text { geweld. }\end{array}$ & $\begin{array}{l}\text { - sociale steun van het informele netwerk van de } \\
\text { ouders }\end{array}$ \\
\hline
\end{tabular}


\begin{tabular}{|l|l|}
\hline & \\
\hline
\end{tabular}

Tabel 4: Risicokenmerken (arm, laag opgeleid, allochtoon, éénouder gezin) versus psychosociale problemen bij het kind

\begin{tabular}{|c|c|}
\hline $\begin{array}{l}\text { Aantal risico } \\
\text { kenmerken }\end{array}$ & Psychosociale problemen \\
\hline Geen & $3 \%$ \\
Een & $5 \%$ \\
Twee & $12 \%$ \\
Drie of vier & $16 \%$ \\
\hline
\end{tabular}

Bron: Zeijl et al., 2005

\subsection{Het in beeld brengen van risico en beschermende factoren}

Hoe kunnen de verschillende risico- en beschermende factoren op een juiste manier in beeld gebracht worden door de JGZ professional? In de NCJ Publicatie 'De kracht van zelfregie' (van Heerwaarden \& Pijpers, 2015) worden een aantal hulpmiddelen en methodieken beschreven, zoals '360을 CHILDoc', de GIZ methodiek, en de Zelfredzaamheid-Matrix (ZRM). Dit zijn algemene methodieken, deze zijn niet speciaal gericht op risico- en beschermende factoren voor psychosociale problemen.

360 CHILDoc is een digitaal instrument voor de JGZ om gegevens over een kind actief met ouder(s) en zorgketenpartners te bespreken. Het instrument biedt een digitale overzichtspagina waarin de JGZ-gegevens over het kind en zijn omgeving in één beeld weergegeven worden. De GIZ methodiek is ontwikkeld door de GGD Hollands Midden. GIZ staat voor Gezamenlijk Inschatten Zorgbehoeften. Door het gebruik van de GIZ-methodiek schatten de JGZ-medewerkers samen met ouders en kinderen de zorgbehoeften van de kinderen en het gezin in, met als doel om vast te stellen welke ondersteuning het beste past bij de gezinssituatie (Zie voor verdere informatie: www.ggdhm.nl).

De Zelfredzaamheid-Matrix (ZRM) is een instrument waarmee de professional de mate van zelfredzaamheid van jongere en ouder(s) eenvoudig en volledig kan beoordelen, op 11 verschillende domeinen.

Tenslotte is het van belang om bij een professionele probleeminventarisatie altijd aandacht te besteden aan de familieanamnese: in een gesprek wordt het voorkomen van (erfelijke) aandoeningen en stoornissen in de familie besproken. Ook bij vervolgcontacten dient deze informatie actueel gehouden te worden.

\section{Referenties}

Asscher, J. J., \& Paulussen-Hoogeboom, M. C. (2005). Invloed van risico-en protectieve factoren op ontwikkeling en opvoeding van jonge kinderen. Kind en Adolescent, 26(1), 56-69.

Alvik, A., Aalen, O. O., \& Lindemann, R. (2013). Early Fetal Binge Alcohol Exposure Predicts High Behavioral Symptom Scores in 5.5-Year-Old Children. Alcoholism: Clinical and Experimental Research, 37, 1954-1962.

Arpi, E., \& Ferrari, F. (Sep 2013). Preterm birth and behaviour problems in infants and preschool-age children: A review of the recent literature. Developmental Medicine \& Child Neurology, 55(9), 788-796.

Ashford, J., Van Lier, P. A., Timmermans, M., Cuijpers, P., \& Koot, H. M. (2008a). Prenatal smoking and internalizing and externalizing problems in children studied from childhood to late 
adolescence. Journal of the American Academy of Child \& Adolescent Psychiatry, 47(7), 779-787.

Ashford, J., Smit, F., van Lier, Pol A. C, Cuijpers, P., \& Koot, H. M. (2008b). Early risk indicators of internalizing problems in late childhood: A 9-year longitudinal study. Journal of Child Psychology and Psychiatry, 49(7), 774-780.

Baar, A. L. van, Vermaas, J., Knots, E., Kleine, M. J. K. de, \& Soons, P. (2009). Functioning at School Age of Moderately Preterm Children Born at 32 to 36 Weeks' Gestational Age. Pediatrics, 124(1), 251-257.

Baker, C. E., \& Rimm-Kaufmann, S. E. (2014). How Homes Influence Schools: Early Parenting Predicts African American Children Classroom Social-Emotional Functioning. Psychology in the Schools, 51(7), 722-735.

Barnett, M. A., Scaramella, L. V., Neppl, T. K., Ontai, L. L., \& Conger, R. D. (Oct 2010). Grandmother involvement as a protective factor for early childhood social adjustment. Journal of Family Psychology, 24(5), 635-645.

Bayer, J. K., Ukoumunne, O. C., Lucas, N., Wake, M., Scalzo, K., \& Nicholson, J. M. (Oct 2011). Risk factors for childhood mental health symptoms: National longitudinal study of australian children. Pediatrics, 128(4), e865-e879.

Beck, C. T. (1999). Maternal depression and child behaviour problems: a meta-analysis. Journal of Advanced Nursing, 29,623-629.

Beer, R., Verlinden, E. \& Lindauer, R. (2013). Protocol Classificatie, screening en diagnostiek van kinderen en adolescenten met traumagerelateerde problematiek. Amsterdam: de Bascule.

Berdan, L. E., Keane, S. P., \& Calkins, S. D. (Jul 2008). Temperament and externalizing behavior: Social preference and perceived acceptance as protective factors. Developmental Psychology, 44(4), 957-968.

Biederman, J., Faraone, S. V., Hirshfeld-Becker, D. R., Friedman, D., Robin, J. A., \& Rosenbaum, J. F. (2001). Patterns of psychopathology and dysfunction in high-risk children of parents with panic disorder and major depression. American Journal of Psychiatry

Bot, M., de Leeuw - den Bouter, B. J. E., \& Adriaanse, M. C. (2011). Prevalence of psychosocial problems in Dutch children aged 8-12 years and its association with risk factors and quality of life. Epidemiology \& Psychiatric Sciences, 20, 357-365.

Bowes, L., Maughan, B., Caspi, A., Moffitt, T. E., \& Arseneault, L. (2010). Families promote emotional and behavioural resilience to bullying: Evidence of an environmental effect. Journal of Child Psychology and Psychiatry, and Allied Disciplines, 51(7), 809-817.

Cabaj, J. L., McDonald, S. W., \& Tough, S. C. (2014). Early childhood risk and resilience factors for behavioural and emotional problems in middle childhood. BMC Pediatrics, 14, 166.

Caspi, A, Henry, B, McGee RO, Moffit,TE, \& al., (1995). Temperamental origins of child and adolescent behavior problems: from age three to fifteen. Child Development, 66 (1), 55-68.

Cavaleri, M. A., Olin, S. S., Kim, A., Hoagwood, K. E., \& Burns, B. J. (2011). Family support in prevention programs for children at risk for emotional/behavioral problems. Clinical Child and Family Psychology Review, 14(4), 399-412.

Chen, J. (2014). Asthma and child behavioral skills: Does family socioeconomic status matter? Social Science \& Medicine, 115 Aug, 38-48.

Clark, D. B., Cornelius, J., Wood, D., \& Vanyukov, M. (2004). Psychopathology risk transmission in children of parents with substance use disorders. American Journal of Psychiatry, 161(4), 685-691.

Coren, E., Thomae, M., \& Hutchfield, J. (2011). Parenting training for intellectually disabled parents: A Cochrane systematic review. Research on Social Work Practice, 21(4), 432-441. 
Crone MR, Bekkema N, Wiefferink CH, Reijneveld SA. (2010). Professional identification of psychosocial problems among children from ethnic minority groups: room for improvement. Journal of Pediatrics, 156, 277-84.

Cummings, E. M., \& Davies, P. T. (1994). Maternal depression and child development. Journal of Child Psychology and Psychiatry, 35(1), 73-112.

Cuijpers, P., Langendoen, Y., \& Bijl, R. V.(1999). Psychiatric disorders in adult children of problem drinkers: Prevalence, first onset, and comparison with other risk factors. Addiction, 94, 1489-1498.

Crick, N. R., \& Zahn - Waxler, C. (2003). The development of psychopathology in females and males: Current progress and future challenges. Development and psychopathology, 15(03), 719-742.

Deković, M., Janssens, J. M., \& As, N. (2003). Family predictors of antisocial behavior in adolescence. Family Process, 42(2), 223-235.

Dorsselaer, M. van, M. de Looze, E. Vermeulen-Smit S. de Roos, J. Verdurmen, T. ter Bogt en W. Vollebergh (2010). Gezondheid, welzijn en opvoeding van jongeren in Nederland. HBSC 2009'. Utrecht, Trimbos-instituut.

Engel, G.L. (1980). The clinical application of the biopsychosocial model. The American Journal of Psychiatry, 137, 535-544.

Ezpeleta, L., Granero, R., de la Osa, N., \& Domenech, J. M. (Jul 2008). Risk factor clustering for psychopathology in socially at-risk spanish children. Social Psychiatry and Psychiatric Epidemiology, 43(7), 559-568.

Fazel, M., Reed, R. V., Panter-Brick, C., \& Stein, A. (2012). Mental health of displaced and refugee children resettled in high-income countries: risk and protective factors. The Lancet, 379(9812), 266-282.

Fearon RP, IJzendoorn van MH, Bakermans-Kranenburg MJ, Lapsley A, Roisman GI. The Significance of Insecure Attachment and Disorganization in the Development of Children's Externalizing Behavior: A Meta-Analytic Study. Child Development, March/April 2010, Volume 81, Number 2, Pages 435-456.

Feldman, M. A. (2002). Children of parents with intellectual disabilities. In R. McMahon, \& R. D. Peters (Eds.), The effects of parental dysfunction on children (pp. 205-223). New York, NY: Kluwer Academic.

Flouri, E., Tzavidis, N., \& Kallis, C. (Jun 2010). Adverse life events, area socioeconomic disadvantage, and psychopathology and resilience in young children: The importance of risk factors' accumulation and protective factors' specificity. European Child \& Adolescent Psychiatry, 19(6), 535-546.

Folger, S. F., \& Wright, M. O. D. (2013). Altering risk following child maltreatment: Family and friend support as protective factors. Journal of Family Violence, 28(4), 325-337.

Garcia Reid, P., Peterson, C.H., Reid, R. J., \& Peterson, N. A. (2013). The protective effects of sense of community, multigroup ethnic identity, and self-esteem against internalizing problems among Dominican youth: Implications for social workers. Social Work in Mental Health, 11(3), 199-222.

Gelauff-Hanzon, C. (red.) (1994). Nieuwkomers van 12-18 jaar. Schets van een situatie. Leiden: PEWA.

Gere, M. K., Villabo, M. A., Torgersen, S., \& Kendall, P. C. (Aug 2012). Overprotective parenting and child anxiety: The role of co-occurring child behavior problems. Journal of Anxiety Disorders, 26(6), 642-649.

Goldsmith, H. H., Buss, A. H., Plomin, R., Rothbart, M. K., Thomas, A., Chess, S., ... \& McCall, R. B. (1987). Roundtable: What is temperament? Four approaches. Child Development, 58, 505-529. 
Goodman, S. H., Rouse, M. H., Connell, A. M., Broth, M. R., Hall, C. M., \& Heyward, D. (2011). Maternal depression and child psychopathology: a meta-analytic review. Clinical Child and Family Psychology Review, 14(1), 1-27.

Goosen, S., Stronks, K., \& Kunst, A.E. (2014). Frequent relocations between asylum-seeker centres are associated with mental distress in asylum-seeking children: a longitudinal medical record study. International Journal of Epidemiology, 1-11.

Goossens, F., \& Van der Zanden, R. (2012). Factsheet KOPP/KVO Utrecht: Trimbos-Instituut.Groh AM, Roisman GI, IJzendoorn van MH, Bakermans-Kranenburg MJ. Fearon RP. The Significance of Insecure and Disorganized Attachment for Children's Internalizing Symptoms: A Meta-Analytic Study. Child Development, March / April 2012, Volume 83, Number 2, Pages 591-610

Halligan, S. L., Murray, L., Martins, C., \& Cooper, P. (2011). Maternal depression and psychiatric outcomes in adolescent offspring: A 13-year longitudinal study. Journal of Affective Disorders, 97, 145-154.

Harland, P., Reijneveld, S. A., Brugman, E., Verloove-Vanhorick, S. P., \& Verhulst, F. C. (2002). Family factors and life events as risk factors for behavioural and emotional problems in children. European child \& adolescent psychiatry, 11(4), 176-184.

Herbert, S. D., Harvey, E. A., LugoCandelas, C. I., \& Breaux, R. P. (Jul 2013). Early fathering as a predictor of later psychosocial functioning among preschool children with behavior problems. Journal of Abnormal Child Psychology, 41(5), 691-703.

Heberle, A. E., Krill, S. C., Briggs-Gowan, M. J., \& Carter, A. S. (2014). Predicting externalizing and internalizing behavior in kindergarten: Examining the buffering role of early social support. Journal of Clinical Child \& Adolescent Psychology, 4, 1-15.

Heerwaarden, Y. van \& Pijpers, F., (2015). De kracht van zelfregie: Samen komen tot passende hulp en ondersteuning. Nederlands Centrum Jeugdgezondheid (NCJ), Utrecht.

Hipwell, A. E., Goossens, F. E., Melhuish, E. C., \& Kumar, R. (2000). Severe maternal psychopathology and infant-mother attachment. Development and Psychopathology, 2, 157-175.

Janssen MM, Verhulst FC, Bengi-Arslan L, Erol N, Salter CJ, Crijnen AA.Comparison of self-reported emotional and behavioral problems in Turkish immigrant, Dutch and Turkish adolescents. Soc Psychiatry Psychiatr Epidemiol 2004;39:133-40.

Jong, A. de, Stremmelaar, B., \& Looij, J. (2014). Goed genoeg opvoederschap: Handreiking voor ondersteuning van ouders met een verstandelijke beperking. De Amerpoort. Gedownload op 2-1-2016 van http://www.amerpoort.nl/over-amerpoort/publicaties/boeken.html.

Junger, M., Mesman, J., \& Meeus, W. (2003). Psychosociale problemen bij adolescenten. Prevalentie, risicofactoren en preventie. Assen: Van Gorcum.

Kabiru, C. W., Elung'ata, P., Mojola, S. A., \& Beguy, D. (2014). Adverse life events and delinquent behavior among Kenyan adolescents: A cross-sectional study on the protective role of parental monitoring, religiosity, and self-esteem. Child and Adolescent Psychiatry and Mental Health; 8 (24).

Kaptein, S., Jansen, D. E. M. C., Vogels, A. G. C., \& Reijneveld, S. A. (2008). Mental health problems in children with intellectual disability: use of the Strengths and Difficulties Questionnaire. Journal of Intellectual Disability Research, 52(2), 125-131.

Karabekiroglu, K., Uslu, R., Kapci-Seyitoglu, E. G., Ozbaran, B., Oztop, D. B., Ozel-Ozcan, O., . . . Cengel-Kultur, E. S. (2013). A nationwide study of social-emotional problems in young children in turkey. Infant Behavior \& Development, 36(1), 162-170.

Kraemer HC, Stice E, Kazdin A, Offord D, Kupfer D. How do risk factors work together? Mediators, moderators, and independent, overlapping, and proxy risk factors. Am J Psychiatry. 2001 Jun;158(6):848-56. Review. 
McLaughlin, K. A., Gadermann, A. M., Hwang, I., Sampson, N. A., Al-Hamzawi, A., Andrade, L. H., ... \& Caldas-de-Almeida, J. M. (2012). Parent psychopathology and offspring mental disorders: results from the WHO World Mental Health Surveys. The British Journal of Psychiatry, 1-10

Monshouwer, K., Huizink, A. C., Harakeh, Z., Raaijmakers, Q. A., Reijneveld, S. A., Oldehinkel, A. J., ... \& Vollebergh, W. A. (2011). Prenatal smoking exposure and the risk of behavioral problems and substance use in adolescence: the TRAILS study. European Addiction Research, 17(6), 342-350.

Motlagh, M. G., Sukhodolsky, D. G., LanderosWeisenberger, A., Katsovich, L., Thompson, N., Scahill, L., ... Leckman, J. F. (2011). Adverse effects of heavy prenatal maternal smoking on attentional control in children with ADHD. Journal of Attention Disorders, 15(7), 593-603.

Myhre MC, Dyb GA, Wentzel-Larsen T, Grogaard JB, Thoresen S. Maternal childhood abuse predicts externalizing behavior in toddlers: A prospective cohort study. Scandinavian Journal of Public Health, 2013; 0: 1-7.

Oeseburg, B., Jansen, D. E., Groothoff, J. W., Dijkstra, G. J., \& Reijneveld, S. A. (2010). Emotional and behavioural problems in adolescents with intellectual disability with and without chronic diseases. Journal of Intellectual Disability Research, 54(1), 81-89.

Oliva, A., Jimenez, J. M., \& Parra, A. (2009). Protective effect of supportive family relationships and the influence of stressful life events on adolescent adjustment. Anxiety, Stress, and Coping, 22(2), 137-152.

Pargas, R. C., Brennan, P. A., Hammen, C., \& Le Brocque, R. (2010). Resilience to maternal depression in young adulthood. Developmental Psychology, 46(4), 805-814. doi:10.1037/a0019817 [doi]

Plant DT, Barker ED, Waters CS, Pawlby S, Pariante CM. Intergenerational transmission of maltreatment and psychopathology: the role of antenatal depression. Psychological Medicine (2013), 43, 519-528.

Potijk, M. R., Winter, A. F. de, Bos, A. F., Kerstjens, J. M., \& Reijneveld, S. A., (2012). Higher rates of behavioural and emotional problems at preschool age in children born moderately preterm. Arch Dis Child, 97, 112-117.

Reijneveld, S. A., Kleine, M. J. de, Baar, A. L. van, Kollée, L. A. A., Verhaak, C. M., Verhulst, F. C., \& Verloove-Vanhorick, S. P. (2006). Behavioural and emotional problems in very preterm and very low birthweight infants at age 5 years. Arch Dis Child Fetal Neonatal Ed, 91, F423-F428.

Reijneveld S.A., A.G.C. Vogels, F. Hoekstra, M.R.Crone (2006). Use of the Pediatric Symptom Checklist for the detection of psychosocial problems in preventive child healthcare. BMC Public Health, 6, 1471-2458.

Reijneveld, S. A., Brugman, E., Verhulst, F. C., \& Verloove-Vanhorick, S. P. (2005). Area deprivation and child psychosocial problems. Social psychiatry and psychiatric epidemiology, 40, 18-23.

Reijneveld, S. A., Crone, M. R., Schuller, A. A., Verhulst, F. C., \& Verloove-Vanhorick, S. P. (2005). The changing impact of a severe disaster on the mental health and substance misuse of adolescents: follow-up of a controlled study. Psychological Medicine, 35, 367-376.

Reijneveld, S. A., Crone, M. R., Verhulst, F. C., \& Verloove-Vanhorick, S. P. (2003). The effect of a severe disaster on the mental health of adolescents: a controlled study. The Lancet, 362, 691-696.

Reijneveld, S. A., Veenstra, R., de Winter, A. F., Verhulst, F. C., Ormel, J., \& de Meer, G. (2010). Area deprivation affects behavioral problems of young adolescents in mixed urban and rural areas: The TRAILS study. The Journal of Adolescent Health : Official Publication of the Society for Adolescent Medicine, 46(2), 189-196.

Reinders, H. S. (2008). Persons with disabilities as parents: What is the problem? Journal of Applied Research in Intellectual Disabilities, 21, 308-314. 
Rexwinkel, M., Schmeets, M., Pannevis, C., \& Derkx, B. (2011). Handboek Infant Mental Health. Inleiding in de ouder-kindbehandeling (pp. 410-411). Assen: Koninklijke van Gorcum.

Romijn, G., Graaf, I. M., \& de Jonge, M. (2010). Kwetsbare kinderen: literatuurstudie over verhoogde risicogroepen onder kinderen van ouders met psychische of verslavingsproblemen. Trimbos-Instituut.

Rijlaarsdam, J., Stevens, G. W., van der Ende, J., Hofman, A., Jaddoe, V. W., Mackenbach, J. P., ... \& Tiemeier, H. (2013). Economic disadvantage and young children's emotional and behavioral problems: mechanisms of risk. Journal of Abnormal Child Psychology, 41, 125-137.

Rijlaarsdam, J., Tiemeier, H., Hofman, A., Jaddoe, V. W., Mackenbach, J. P., Verhulst, F. C., \& Stevens, G. W. (2013). Home environments of infants: Relations with child development through age 3. Journal of Epidemiology and Community Health, 67, 14-20.

Schwartz, CE, Snidman, N \& Kagan J. (1999). Adolescent anxiety as an outcome of inhibited temperament in childhood. Journal of the American Academy of child and adolescent Psychiatry, 38 (8), 1008-1015.

Sieh, D. S., Meijer, A. M., Oort, F. J., Visser-Meily, J. M. A., \& Van der Leij, D. A. V. (2010). Problem behavior in children of chronically ill parents: a meta-analysis. Clinical child and family psychology review, 13(4), 384-397.

Sieh, D. S., Visser-Meily, J. M. A., \& Meijer, A. M. (2013). Differential outcomes of adolescents with chronically ill and healthy parents. Journal of child and family studies, 22(2), 209-218.

Taggart, L., Taylor, D., \& McCrum-Gardner, E. (2010). Individual, life events, family and socio-economic factors associated with young people with intellectual disability and with and without behavioural/emotional problems. Journal of Intellectual Disabilities : JOID, 14(4), 267-288.

Talge, N. M., Holzman, C., Wang, J., Lucia, V., Gardiner, J., \& Breslau, N. (2010). Late-Preterm Birth and Its Association With Cognitive and Socioemotional Outcomes at 6 Years of Age. Pediatrics, 126(6), 1124-1131.

Teerikangas, OM, Aronen, ET, Martin RP \& Huttunen, MO (1998). Effect of infant temperament and early intervention on the psychiatric symptoms of adolescents. Journal of the American Academy of Child and adolescent Psychiatry, 37 (10), 1070-1076,

Timmermans M, van Lier PA, Koot HM. The role of stressful events in the development of behavioural and emotional problems from early childhood to lateadolescence. Psychol Med. 2010 Oct;40(10):1659-68.

Van Steijn L, de Winter AF, Reijneveld SA (2014). Stabiliteit en verandering van psychosociale gezondheid en leefstijl bij adolescenten en mogelijkheden voor interventies. Bouwstenen voor het Extra Contactmoment Adolescenten. Groningen: UMCG, Rijksuniversiteit Groningen.

Velders, F. P., Dieleman, G., Henrichs, J., Jaddoe, V. W., Hofman, A., Verhulst, F. C., . . . Tiemeier, H. (2011). Prenatal and postnatal psychological symptoms of parents and family functioning: The impact on child emotional and behavioural problems. European Child \& Adolescent Psychiatry, 20(7), 341-350

Visser A, Huizinga GA, Graaf van der WTA ,Hoekstra HJ, Hoekstra-Weebers JEHM. The impact of parental cancer on children and the family: a review of the literature. Cancer Treatment Reviews (2004) 30, 683-694

Weaver, C. M., Shaw, D. S., Dishion, T. J., \& Wilson, M. N. (2008). Parenting self-efficacy and problem behavior in children at high risk for early conduct problems: The mediating role of maternal depression. Infant Behavior \& Development, 31(4), 594-605.

Whittaker, J. E. V., Harden, B. J., See, H. M., Meisch, A. D., \& T'Pring, R. W. (2011). Family risks and protective factors: Pathways to Early Head Start toddlers' social-emotional functioning. Early Childhood Research Quarterly, 26(1), 74-86. 
Willems, D. L., De Vries, J. N., Isarin, J., \& Reinders, J. S. (2007). Parenting by persons with intellectual disability: an explorative study in the Netherlands. Journal of Intellectual Disability Research, 51(7), 537-544.

Wu, Y.C., Hsieh, W.S., Hsu, C.H., Chang, J.H., Chou, H.C., Hsu, H.C., .... \& Jeng, S.F. (2016). Intervention effects on emotion regulation in preterm infants with very low birth weight: A randomize controlled trial. Research in Developmental Disabilities, 48, 1-12.

Zahn-Waxler, C., Shirtcliff, E. A., \& Marceau, K. (2008). Disorders of childhood and adolescence: Gender and psychopathology. Annu. Rev. Clin. Psychol., 4, 275-303.

Zeijl, E. M. Crone, M. Wiefferink, K., Keuzenkamp, S. \& Reijneveld, S.A. (2005). Kinderen in Nederland. Den Haag/Leiden, SCP/TNO Kwaliteit van Leven.

Zoon, M., \& Foolen, N. (2014). Wat werkt bij Wat werkt bij licht verstandelijk beperkte ouders? Utrecht: Nederlands Jeugdinstituut 


\section{Thema 2 Vroegsignalering van psychosociale problemen}

\section{Inleidling}

De JGZ kan op verschillende manieren informatie verzamelen om psychosociale problemen bij kinderen te signaleren, zoals observatie, de dialoog met ouder en kind en gebruik van een signaleringsinstrument. Het gebruik van goede (d.w.z. valide) instrumenten kan de signalering van psychosociale problemen door de JGZ aanzienlijk verbeteren. In dit hoofdstuk worden de vroegsignaleringsinstrumenten beschreven die in Nederland onderzocht zijn op validiteit. Ook wordt ingegaan op de weerstand die ouders en/of kinderen kunnen ervaren bij het invullen van dergelijke vragenlijsten.

\section{Aanbevelingen}

- $\quad$ Het wordt aanbevolen om per genoemde leeftijdsperiode een veelbelovend of valide instrument te gebruiken als hulpmiddel voor de opsporing van psychosociale problemen o $\quad$ 0-4 jaar, kies één van onderstaande instrumenten:

- $\quad$ SPARK voor opvoedings- en ontwikkelingsproblemen (18 maanden)

- $\quad$ DMO protocol voor psychosociale problemen (0-18 maanden)

- $\quad$ BITSEA (valide voor twee jarigen)

- $\quad$ SDQ 3-4 ouderversie (valide voor 3 en 4 jarigen)

Toelichting: BITSEA en SDQ zijn geschikt voor de vroegsignalering van psychosociale problemen van respectievelijk twee en 3-4 jarigen. Voor kinderen jongeren dan 2 jaar zijn de DMO en SPARK beschikbaar voor signalering van risico's bij de opvoeding.

$\begin{array}{ll}\text { o } & \text { 4-7 jaar: SDQ 4-17 ouderversie } \\ \circ & \text { 8-12 jaar: SDQ 4-17 ouderversie } \\ 0 & \text { 13-14 jaar, kies één van onderstaande instrumenten } \\ - & \text { SDQ kindversie } \\ & -\quad \text { KIVPA }\end{array}$

- De SDQ kindversie is een veelbelovend instrument voor kinderen van 15 jaar en ouder en kan voor de desbetreffende leeftijd gebruikt worden

- $\quad$ De SDQ leerkrachtversie is een valide instrument voor kinderen in de leeftijd van 4-7 jarigen en kan aanvullend (naast de ouderversie) voor deze leeftijdsgroep gebruikt worden.

- Wees alert dat een instrument niet het klinisch oordeel kan vervangen, het gebruik van deze instrumenten is een onderdeel van het totale proces van signaleren. Naast het gebruik van instrumenten blijft de professionele inschatting en het gesprek met ouder en/of jeugdige van grote waarde.

- $\quad$ Bij het gebruik van vragenlijsten dient aan ouders (mondeling of schriftelijk) uitleg gegeven te worden over het doel van de vragenlijsten.

- $\quad$ Als er naar aanleiding van het gesprek met ouders en/of kind, klinische observatie en/of score op een vroegsignaleringsinstrument behoefte is aan verheldering van de problematiek kan een diagnostisch instrument worden ingezet. Gebruik het schema van het NCJ Richtinggevende diagnostiek (NCJ) om te bepalen welk instrument ingezet kan worden .

Aanbevelingen voor doorontwikkeling van instrumenten of behoefte aan verder onderzoek

- $\quad$ De SDQ kindversie dient gevalideerd te worden voor kinderen van 15 jaar en ouder.

- $\quad$ De Psycat is een valide vroegsignaleringsinstrument voor ouders van kinderen van 7-11 jaar, dit instrument dient geschikt te worden gemaakt voor toepassing in de JGZ. 
- $\quad$ Er dient onderzocht te worden wat het toegevoegde effect is van afname van instrumenten op meerdere momenten tijdens een levensloop van een kind.

\section{Uitgangsvragen}

- hoe kunnen JGZ-professionals psychosociale problemen signaleren bij nul-tot vierjarigen en veertien-plussers?

- Wat zijn, voor kinderen boven de veertien, valide instrumenten voor de JGZ om psychosociale problemen te signaleren zoals de Emovo, SDQ en KIVPA?

- Hoe kunnen JGZ-professionals psychosociale problemen signaleren bij verschillende leeftijdsgroepen als valide instrumenten ontbreken?

\section{Onderbouwing}

\section{0 - 4 jarigen}

\section{\begin{tabular}{l|l} 
Niveau & Conclusie
\end{tabular}}

\begin{tabular}{|c|c|c|}
\hline & $\begin{array}{l}\text { Gebruik een veelbelovend of valide instrument voor de } \\
\text { opsporing van psychosociale problemen bij 0-4 jarigen }\end{array}$ & \\
\hline 3 & $\begin{array}{l}\text { Er zijn aanwijzingen dat de SPARK een goed instrument is om } \\
\text { psychosociale problemen bij kinderen van } 18 \text { maanden te } \\
\text { signaleren }\end{array}$ & $\begin{array}{l}\text { B (Staal et al., 2013; Stel et } \\
\text { al., 2012) }\end{array}$ \\
\hline 3 & $\begin{array}{l}\text { Er is een aanwijzing dat het DMO-protocol een goed instrument } \\
\text { is om psychosociale problemen bij kinderen van } 2 \mathrm{t} / \mathrm{m} 18 \text { maanden } \\
\text { te signaleren }\end{array}$ & C (Hielkema , 2015) \\
\hline 1 & $\begin{array}{l}\text { Het is aangetoond de BITSEA een goed instrument is om } \\
\text { psychosociale problemen bij kinderen van } 2 \text { jaar te signaleren }\end{array}$ & $\begin{array}{l}\text { A2 (Kruizinga et al., 2012; } \\
\text { de Wolff et al., 2013) }\end{array}$ \\
\hline 2 & $\begin{array}{l}\text { Het is aannemelijk dat de BITSEA geen goed instrument is om } \\
\text { psychosociale problemen bij kinderen van } 6 \text { en } 14 \text { maanden te } \\
\text { signaleren }\end{array}$ & A2 (de Wolff et al., 2013) \\
\hline 2 & $\begin{array}{l}\text { Het is aannemelijk dat de ASQ:SE geen goed instrument is om } \\
\text { psychosociale problemen bij kinderen van } 6 \text { maanden } t / m \text { m } 24 \\
\text { maanden en bij kinderen van } 3 \text { en } 4 \text { jaar te signaleren }\end{array}$ & $\begin{array}{l}\text { A2 (de Wolff et al., 2013; } \\
\text { Theunissen et al., 2015) }\end{array}$ \\
\hline 2 & $\begin{array}{l}\text { Het is aannemelijk dat de KIPPPI geen goed instrument is om } \\
\text { psychosociale problemen bij kinderen van } 6 \text { en } 14 \text { maanden en bij } \\
3 \text { en } 4 \text { jarigen te signaleren }\end{array}$ & $\begin{array}{l}\text { A2 (de Wolff et al., 2013; } \\
\text { Theunissen et al., 2015) }\end{array}$ \\
\hline 2 & $\begin{array}{l}\text { Er zijn geen eenduidige conclusies te trekken over of de KIPPPI } \\
\text { een goed instrument is om psychosociale problemen bij kinderen } \\
\text { van } 2 \text { jaar te signaleren }\end{array}$ & $\begin{array}{l}\text { A2 (de Wolff et al., 2013; } \\
\text { Kruizinga et al., 2012) }\end{array}$ \\
\hline 2 & $\begin{array}{l}\text { Het is aannemelijk dat de SDQ ouderversie een goed instrument } \\
\text { is om psychosociale problemen bij kinderen van } 3 \mathrm{t} / \mathrm{m} 4 \text { jaar te } \\
\text { signaleren }\end{array}$ & $\begin{array}{l}\text { A2 (Theunissen et al., 2013; } \\
\text { Theunissen et al., 2015) }\end{array}$ \\
\hline
\end{tabular}

\section{4-12 jarigen}


2 Het is aannemelijk dat de LSPPK geen goed instrument is om

A2 (Vogels et al., 2003) psychosociale problemen bij kinderen van $5 \mathrm{t} / \mathrm{m} 6$ jaar te signaleren

2 Het is aannemelijk dat de SDQ Ouderversie een goed instrument

A2 (Mieloo, 2015) is om psychosociale problemen bij kinderen van $4 \mathrm{t} / \mathrm{m} 7$ jaar en bij $7 \mathrm{t} / \mathrm{m} 12$ jaar te signaleren

$1 \quad$ Het is aangetoond dat de SDQ Leerkrachtversie een goed instrument is om psychosociale problemen bij kinderen van $4 \mathrm{t} / \mathrm{m}$ 7 jaar te signaleren

1 Het is aangetoond dat de PSYCAT een goed instrument is om psychosociale problemen bij kinderen van $7 \mathrm{t} / \mathrm{m} 12$ jaar te signaleren

A2 (Mieloo, 2015; Stone, 2015)

A2 (Vogels et al., 2010; Vogels et al., 2011)

\section{\begin{tabular}{l|l} 
Niveau & Conclusie \\
\hline
\end{tabular}}

$4 \quad$ Wees alert dat een instrument niet het klinisch oordeel kan vervangen, het gebruik van deze instrumenten is een onderdeel van het totale proces van signaleren. Naast het gebruik van instrumenten blijft de professionele inschatting en het gesprek met ouder en/of jeugdige van grote waarde.

4 Bij het gebruik van instrumenten dient aan ouders (mondeling of schriftelijk) uitleg gegeven te worden over het doel van de vragenlijsten.

4 Als er naar aanleiding van het gesprek met ouders en/of kind, klinische observatie en/of score op een vroegsignaleringsinstrument behoefte is aan verheldering van de problematiek kan een diagnostisch instrument worden ingezet. Gebruik het schema van het NCJ Richtinggevende diagnostiek (NCJ) om te bepalen welk instrument ingezet kan worden.

4 Aanbeveling voor onderzoek: de SDQ kindversie dient gevalideerd te worden voor kinderen van 15 jaar en ouder.

4 De Psycat is een valide vroegsignaleringsinstrument voor ouders van kinderen van 7-11 jaar, dit instrument dient geschikt te worden gemaakt voor een productieomgeving.

\section{Literatuur}

werkgroep

werkgroep

werkgroep

werkgroep

werkgroep

\section{2 - 18 jarigen}

\section{\begin{tabular}{l|l} 
Niveau & Conclusie \\
\end{tabular}}

\section{Literatuur}

\section{Gebruik een veelbelovend of valide instrument voor de} opsporing van psychosociale problemen bij 12-18 jarigen

2 Het is aannemelijk dat de SDQ Kindversie een goed instrument is om psychosociale problemen bij kinderen van $13 \mathrm{t} / \mathrm{m} 14$ jaar te signaleren

3 Er is een aanwijzing dat de SDQ Kindversie een goed instrument is om psychosociale problemen bij kinderen van $11 \mathrm{t} / \mathrm{m} 16$ jaar te signaleren
A2 (Vogels et al., 2011)

C (van de Looij-Jansen et al., 2011) 

signaleren

\subsection{Vroegsignalering door de JGZ}

Vroegsignalering is één van de kerntaken van de JGZ. Dit is vastgelegd in het Basispakket JGZ, dat wettelijk verankerd is in de Wet publieke gezondheid (Wpg). De vroegsignalering van psychosociale problemen bij kinderen door de JGZ is zonder instrumenten niet optimaal. In totaal worden $72 \%$ van de kinderen in de leeftijd van 21 maanden tot 4 jaar (Reijneveld et al., 2004; Klein Velderman et al., 2010) en bijna de helft van de 5-15 jarigen met psychosociale problemen (d.w.z. een klinische CBCL score) (Brugman et al., 2001; Theunissen et al., 2012) gemist door de JGZ. De kwaliteit van de vroegsignalering van psychosociale problemen door de JGZ is minder goed bij allochtone kinderen dan bij autochtone kinderen. Slechts 30\% van de Turkse en Marokkaanse kinderen met een psychosociaal probleem wordt geïdentificeerd door de JGZ, terwijl dit bij de autochtone kinderen $60 \%$ is (Crone et al., 2010). In deze studie is een psychosociaal probleem bepaald door middel van de Child Behavior Checklist $(\mathrm{CBCL})$. Mogelijke verklaringen voor deze slechtere opsporing bij allochtone kinderen zijn verschillen in de mate waarin ouders hun zorgen aan een hulpverlener uiten. Ouders uit niet-geïndustrialiseerde landen zijn mogelijk minder bereid om over hun problemen te vertellen buiten de kring van de directe familie, omdat zij dit niet sociaal wenselijk vinden (Middleton, 2000). Maar ook als een ouder problemen kenbaar maakt aan de hulpverlener, kan de besluitvorming van de hulpverlener anders verlopen. Bijvoorbeeld, taalproblemen, culturele verschillen en vooroordelen kunnen een goede interactie tussen ouder en hulpverlener belemmeren (Harmsen et al., 2003; Meeuwesen et al., 2006). Dit kan leiden tot slechtere en of latere signalering en minder effectieve verwijzing.

Het gebruik van goede (d.w.z. valide) instrumenten kan de signalering van psychosociale problemen door de JGZ aanzienlijk verbeteren (Vogels, 2008a; Theunissen et al, 2012a). Een instrument kan niet het klinisch oordeel vervangen, het gebruik van deze instrumenten is een onderdeel van het totale proces van signaleren. Naast het gebruik van instrumenten blijft de professionele inschatting van grote waarde. De professional moet in staat zijn een goede inschatting te maken van de risico's op basis van onder andere de uitkomsten van het instrument. Dit vraagt om bepaalde competenties en deskundigheid van professionals, zoals observerend vermogen, gespreksvaardigheden en deskundigheid op het gebied van gedrags- en ontwikkelingsproblemen. Als het gaat om allochtone jeugd en hun ouders zijn culturele sensitiviteit en interculturele competenties belangrijk. Zie de JGZ richtlijn opvoedingsondersteuning voor een uitgebreide beschrijving van gespreksvaardigheden.

\subsection{Weerstand van ouders om vragenlijsten in te vullen}

De JGZ heeft een taak in het signaleren van risico's die opgroeiende kinderen bedreigen. Een aantal ouders ervaart dit als een opsporingstaak en zijn hier huiverig voor. Onder meer omdat zij de JGZ zien als opsporingsapparaat voor kindermishandeling. Vooral het werken met vragenlijsten maakt hen huiverig, omdat er dan iets 'op papier komt te staan'. Ouders willen helderheid over waarom de JGZ de gegevens vraagt, wat de JGZ met de gegevens doet, waar de gegevens blijven en wie er toegang toe heeft. Ook willen ze graag inspraak in de besluitvorming over eventuele problemen. Bij het gebruik van een vragenlijst als screeningsinstrument is er minder inspraak 
mogelijk. Eventuele onvrede over de JGZ kan te maken hebben met onduidelijkheid over doel, inhoud en uitvoering van de dienstverlening.

Een vragenlijst als psychosociaal signaleringsinstrument is een hulpmiddel om de behoeften en belangen van de jeugdige systematisch in kaart te brengen. Doel en gebruik van een vragenlijst zijn voor veel ouders niet vanzelfsprekend. De JGZ zal dan ook vanaf het eerste contact heel helder moeten zijn over (de legitimatie van) haar taak, het gebruik van vragenlijsten als psychosociale signaleringsinstrumenten daarbij en het nut ervan voor ouder en kind (NCJ, 2013).

\subsection{Het overzicht van signaleringsinstrumenten}

\subsubsection{Vroegsignalering in de prenatale periode}

De zwangere vrouw is vaak nog niet bekend bij de JGZ. Het is belangrijk dat de verloskundig zorgverlener contact legt met de JGZ wanneer zij signaleert dat er risicofactoren tijdens de zwangerschap zijn. Er zijn instrumenten beschikbaar voor het signaleren van risicofactoren tijdens de zwangerschap. Ter informatie, de JGZ-richtlijn kindermishandeling beveelt de volgende instrumenten aan in de prenatale periode:

- ALPHA-NL;

- Checklist Vroegsignalering in de kraamtijd;

- R4U;

- Mind2Care;

- EDINBURGH POSTNATAL DEPRESSION SCALE (EPDS).

De EPDS wordt zowel postnataal als prenataal gebruikt. De Nederlandse EPDS is gevalideerd en betrouwbaar voor postnataal gebruik. Voor prenataal gebruik (EDS) is de validiteit en betrouwbaarheid onzeker (zie ook JGZ-richtlijn kindermishandeling) .

\subsubsection{Vroegsignalering in de leeftijdsgroep $0-4$ jarigen}

De JGZ hanteert momenteel een verscheidenheid aan instrumenten en methoden in het kader van vroegsignalering bij 0-4 jarigen, zoals de KIPPPI, BITSEA, SPARK en het DMO-protocol.

De volgende vroegsignaleringslijsten en gespreksprotocollen voor de leeftijdsgroep 0-4 jaar zijn onderzocht op validiteit in Nederland (Theunissen, 2013; Kruizinga, 2015; Mieloo 2015):

- Structured Problem Analysis of Raising Kids (SPARK): Signaleren van Problemen en Analyse van Risico bij opvoeden en ontwikkeling van Kinderen;

- DMO-protocol onderdeel van het programma Samen Starten: een gespreksprotocol gericht op het signaleren van opvoedsituaties die risico's op kunnen leveren voor de sociaal/emotionele ontwikkeling van het kind;

- Kort Instrument voor Psychologische en Pedagogische Probleem Inventarisatie (KIPPPI);

- $\quad$ Ages and Stages Questionaire: social-emotional (ASQ:SE) ;

- Brief Infant-Toddler Social and Emotional Assessment (BITSEA);

- Strengths and Difficulties Questionnaire (SDQ).

De SPARK en DMO-protocol zijn gespreksprotocollen die de JGZ kan gebruiken voor de signalering van risico's bij de opvoeding. De overige vier instrumenten (KIPPPI, ASQ:SE, BITSEA en de SDQ) zijn vroegsignaleringsinstrumenten specifiek voor psychosociale problemen. Bij deze instrumenten is onderzocht in hoeverre de uitkomsten overeenstemmen met beschikbare criteriumgegevens 
(concurrente validiteit). Vaak is er gebruik gemaakt van de Child Behavior Checklist (CBCL) als gouden standaard (Achenbach et al., 2001). De CBCL is een bewezen goede gevalideerde vragenlijst voor het meten van gedrag en emotionele problemen.

\section{SPARK}

De SPARK (structured Problem Analysis of Raising Kids) is een gespreksprotocol. Met behulp van de SPARK voert de jeugdverpleegkundige een gestructureerd vraaggesprek met de ouder(s) om (risico op) opvoedings- en ontwikkelingsproblemen bij kinderen van 18 maanden vroegtijdig te signaleren. Het uitgangspunt is het perspectief en de ervaring van de ouder, dit wordt gecombineerd met de expertise van de JGZ-professional. De SPARK geeft een indicatie of een kind een laag, verhoogd of hoog risico op opvoed- en ontwikkelingsproblemen heeft. Daarnaast krijgt de jeugdverpleegkundige inzicht in de zorgen, problemen en zorgbehoeften van ouders. De predictieve validiteit van de SPARK is goed tot uitstekend (Staal et al, 2013). Er is namelijk aangetoond dat de risico-inschatting van de SPARK een latere melding bij de voormalige Adviesen Meldpunt Kindermishandeling (AMK) / Bureau Jeugdzorg / VroegTijdig Onderkennen van ontwikkelingsproblematiek en/of gedragsproblematiek (VTO) voorspelt. De overeenkomst van de SPARK met vergelijkbare zelf-rapportage instrumenten, zoals de ASQ:SE is matig (convergente validiteit) (Stel et al., 2012). Een mogelijk verklaring is dat de inhoud en vraagwijze van beide instrumenten teveel van elkaar verschillen. De SPARK kan een goed onderscheid maken tussen ouders van lage en hoge sociaal economische status (discriminante validiteit). $\mathrm{Er}$ is geen onderzoek beschikbaar waarbij de SPARK wordt vergeleken met een criterium zoals de CBCL (concurrente validiteit).

\section{Samen starten en DMO-protocol}

Samen Starten is een programma dat effectieve samenwerking tussen zorgpartners rondom jonge kinderen beoogt. Binnen dit programma is een DMO-gespreksprotocol ontwikkeld en geëvalueerd voor kinderen in de leeftijd van 0-18 maanden. Dit protocol is vervolgens doorontwikkeld voor kinderen $\mathrm{t} / \mathrm{m} 4$ jaar. Het DMO-gespreksprotocol is een gespreksprotocol waarin er aandacht is voor de gezins- en omgevingsfactoren die een rol spelen bij de psychosociale ontwikkeling van jonge kinderen. Het doel is om opvoedsituaties die risico's en problemen in de sociaal-emotionele ontwikkeling van jonge kinderen kunnen opleveren, zo vroeg mogelijk te signaleren. Het protocol beslaat vijf domeinen: welbevinden kind, welbevinden ouder, rol partner, sociale steun en obstakels. Het is een systematisch volgsysteem voor ondersteuning in gesprekken met ouders. Het consult op de leeftijd van acht weken wordt gebruikt om bovenstaande aspecten de eerste keer uitgebreid met de ouder(s) te bespreken. In vervolgcontacten wordt al naar gelang de situatie per gezin gedifferentieerd aandacht aan de opvoedingssituatie besteed.

De werking van het DMO-protocol is geëvalueerd door Hielkema (2015). In de regio waar met het DMO-protocol werd gewerkt werden meer en eerder (risico's voor) sociaal-emotionele problematiek gesignaleerd tussen 2 en 18 maanden (klein significant effect) in vergelijking met de controle regio. Er is gebruik gemaakt van het oordeel van de JGZ-professional. Rond de leeftijd van 18 maanden werd geen significante verschillen op de CBCL (Child Behavioural Checklist) gevonden tussen beide regio's. Dit betekent dat geen effect kon worden aangetoond van werken met het DMO-protocol op het psychosociale welbevinden van kinderen. Wel geven ouders significant vaker aan dat de zorg beter aansluit bij de behoefte.

\section{BITSEA}


De BITSEA is een betrouwbaar en valide instrument voor kinderen in de leeftijd van 24 maanden. De BITSEA heeft op deze leeftijd een grote overeenkomst met de CBCL (Kruizinga et al, 2012a; de Wolff et al., 2013), en kan daarom een goed onderscheid maken tussen kinderen met en zonder psychosociale problemen. Tevens kan de BITSEA de signalering bij kinderen van 24 maanden door de JGZ verbeteren (de Wolff et al., 2013). Voor kinderen in de leeftijd van 14 maanden heeft de BITSEA een lage overeenkomst met de CBCL en kan daarom voor deze leeftijdsgroep maanden niet worden aangeraden (de Wolff et al., 2013).

\section{ASQ:SE}

De ASQ:SE is geen valide instrument voor de onderzochte leeftijdsgroepen van 6 maanden $\mathrm{t} / \mathrm{m} 48$ maanden. De overeenkomst van de ASQ:SE met de CBCL is laag (de Wolff et al., 2013; Theunissen et al., 2015).

\section{KIPPPI}

Onderzoek laat zien dat de validiteit van de KIPPPI (overeenkomst met de CBCL) op de leeftijden 6 maanden t/m 48 maanden slecht is (Wolf et al., 2013; Theunissen et al., 2015). Echter, een ander onderzoek uitgevoerd door Kruizinga laat zien dat de overeenstemming tussen de KIPPPI en de CBCL goed is bij kinderen van 24 maanden (Kruizinga et al., 2012b).

\section{SDQ 3-4 jaar}

De SDQ ouderversie bestaat uit twee leeftijdversies, de SDQ voor 3-4 jarigen en de SDQ voor 4-17 jaar. De SDQ 3-4 is een betrouwbaar en valide instrument voor de leeftijdsgroep 3 en 4 jaar. Op deze leeftijd heeft de SDQ (totaalscore) een uitstekend overeenkomst met het CBCL criterium. Dit geeft aan dat de SDQ een goed onderscheid kan maken tussen kinderen met en zonder problemen. Tevens kan de SDQ de signalering door de JGZ verbeteren (Theunissen et al., 2013a; Theunissen et al., 2015).

\subsubsection{Vroegsignalering in de leeftijdsgroep 5-12 jarigen}

In de leeftijdsgroep 5-12 jaar heeft de JGZ twee reguliere contactmomenten: het contactmoment in groep 2 en in groep 6/7. Onderzoek heeft aangetoond dat bij beide contactmomenten door het merendeel van de JGZ-organisaties een signaleringslijst wordt gebruikt voor de opsporing van psychosociale problemen (Theunissen et al., 2013b). Behalve een SDQ ouderversie is er ook SDQ leerkrachtversie beschikbaar. Het is onduidelijk hoe vaak de leerkrachtversie wordt gebruikt door de Jeugdgezondheidszorg.

De volgende vroegsignaleringslijsten voor de leeftijdsgroep 5-12 jaar zijn onderzocht op validiteit in Nederland:

- $\quad$ Landelijke Signaleringslijst Psychosociale Problemen bij Kleuters (LSPPK);

- $\quad$ Strengths and Difficulties Questionnaire (SDQ);

- Psycat.

Bij deze instrumenten is onderzocht in hoeverre de uitkomsten overeenstemmen met beschikbare criteriumgegevens (concurrente validiteit). Vaak is er gebruik gemaakt van de Child Behavior Checklist (CBCL) als gouden standaard (Achenbach et al., 2001). De CBCL is een bewezen goede gevalideerde vragenlijst voor het meten van gedrag en emotionele problemen.

\section{Landelijke Signaleringslijst Psychosociale Problemen bij Kleuters (LSPPK)}

De LSPPK wordt ingevuld door ouders van kleuters, en haalt met name aandachtsproblemen en sociale problemen naar boven. Uit onderzoek is naar voren gekomen dat met de LSPPK veel 5-6 
jarigen onterecht gesignaleerd worden of niet gesignaleerd worden terwijl er wel een probleem is (Vogels et al., 2003). De vragenlijst is aangepast, maar de validiteit daarvan is niet onderzocht.

\section{SDQ ouderversie}

De SDQ meet de aanwezigheid van psychosociale problemen en de invloed van deze problemen op het dagelijks leven. Op de leeftijd van 4-7 jaar heeft de SDQ ouderversie een uitstekend overeenkomst met het CBCL criterium (Mieloo, 2015; Stone., 2014). Mieloo (2015) heeft aangetoond voor kinderen van 5 en 6 jaar dat het onderscheidend vermogen van de SDQ (totaalscore) ook acceptabel is voor subgroepen op basis van geslacht, opleidingsniveau van ouder en etniciteit. In andere woorden de SDQ kan ook acceptabel psychosociale problemen signaleren bij kinderen van ouders met bijvoorbeeld een laag opleidingsniveau of bij allochtonen. De predictieve validiteit van de SDQ-ouderversie is goed wat blijkt uit het feit dat naarmate ouders hoger scoren op de SDQ, zij ook vaker een beroep doen op hulpverlening i.v.m. opvoedingsproblemen (Stone et al., 2014).

Voor de leeftijdsgroep van 7-12 jaar (contactmoment groep 6/7) heeft ook de ouderversie (kindversie is beschikbaar vanaf 11 jaar) van de SDQ een uitstekende overeenkomst met de $\mathrm{CBCL}$ (Vogels et al., 2009). De ouderversie van de SDQ is op verzoek van GGD Nederland landelijk geïmplementeerd als het signaleringsinstrument voor psychosociale problematiek bij 7-12 jarigen binnen de JGZ (GGD Nederland, 2006).

\section{SDQ Leerkracht versie}

Op de leeftijd van 4-7 jaar heeft de SDQ leerkrachtversie een uitstekend overeenkomst met het CBCL criterium (Teacher Report Form) (Mieloo, 2015; Stone, 2014). Mieloo (2015) heeft aangetoond voor kinderen van 5 en 6 jaar dat het onderscheidend vermogen van de SDQ leerkrachtversie (totaalscore) ook acceptabel is voor subgroepen op basis van geslacht, opleidingsniveau van ouder en etniciteit.

\section{Psycat}

De Psycat is een alternatief voor bestaande instrumenten om psychosociale problemen bij kinderen te signaleren. De Psycat is een internetapplicatie die ouders invullen voor de signalering van psychosociale problemen bij kinderen in de leeftijd van 7-12 jaar. De Psycat meet de zwaarte van psychosociale problemen op vier schalen: een Totaalscore, Internaliserende problemen, Externaliserende problemen en Hyperactiviteit. In vergelijking met de bestaande schriftelijke vragenlijsten biedt de Psycat de volgende voordelen: 1) De Psycat is een zeer kort instrument. Ouders hoeven een minimaal aantal vragen te beantwoorden (gemiddeld 12 vragen). 2) De Psycat kan een goede schatting maken van de zwaarte van de aanwezige problematiek, de overeenkomst van de totale schaal van de Psycat met de CBCL (criterium validiteit) is hoog. En, anders dan bij beschikbare schriftelijke vragenlijsten, geldt dat ook voor de subschalen van de Psycat. Dat blijkt onder andere uit onderzoek dat daarnaar is gedaan (Vogels 2010; Vogels 2011). 3) De resultaten zijn voor de JGZ, eveneens via internet, direct beschikbaar, zonder dat de JGZ tijd moet investeren om de vragenlijsten te scoren.

De Psycat maakt gebruik van CAT, computerized adaptive testing. Met die techniek wordt na elk gegeven antwoord een schatting gemaakt van de zwaarte van eventueel aanwezige problematiek. Vervolgens wordt gekeken welk item die schatting kan verbeteren, tot een vooraf bepaalde nauwkeurigheidsgrens is bereikt. Daardoor kunnen allerlei vragen overgeslagen worden, omdat ze niet bijdragen aan een betere schatting. De Psycat is ontwikkeld voor onderzoeksdoeleinde en nog niet geschikt voor dagelijkse toepassing in de JGZ.

\subsubsection{Vroegsignalering in de leeftijdsgroep 12-18 jarigen}


In de leeftijdsgroep van 12-18 jaar heeft de JGZ twee keer contact met de adolescenten. Op de leeftijd van dertien jaar (of klas 2) is een regulier contactmoment in de JGZ. Daarnaast is er een extra contactmoment op de leeftijden van 15/16 jaar. Dit laatste contactmoment wordt op verschillende manieren ingevuld door JGZ-organisaties, bijvoorbeeld in de vorm van een digitaal contactmoment. Voor het signaleren van psychosociale problematiek worden landelijk voor deze leeftijdsgroep voornamelijk de korte indicatieve vragenlijst voor psychosociale problemen bij adolescenten (KIVPA) en de SDQ gebruikt. Beide instrumenten worden door het kind zelf ingevuld. Voor deze leeftijdsgroep bestaat er ook een SDQ ouderversie, maar deze wordt nauwelijks ingezet door de JGZ. Voor het contactmoment van 15/16 jaar wordt veel gebruik gemaakt van de EMOVO. De EMOVO is gericht op een groot aantal gezondheidsonderwerpen, waaronder psychosociale problemen. Deze problemen worden in de EMOVO gemeten met de SDQ kindversie.

De KIVPA is in 1997 ontwikkeld voor gebruik in het voortgezet onderwijs. Op basis van onderzoek (Reijneveld et al., 2003) en ervaring van gebruikers in het veld is in 2004 een nieuwe versie van de KIVPA verschenen. De SDQ en deze nieuwe versie van de KIVPA zijn voor de leeftijdsgroep 13 en 14 jaar gevalideerd voor de Nederlandse situatie (Vogels et al., 2011).

De volgende vroegsignaleringslijsten voor de leeftijdsgroep 12-18 jaar zijn onderzocht op validiteit in Nederland:

- Strengths and Difficulties questionnaire (SDQ), kind en ouderversie

- Korte indicatieve vragenlijst voor psychosociale problemen bij adolescenten (KIVPA)

Bij deze instrumenten is onderzocht in hoeverre de uitkomsten overeenstemmen met beschikbare criteriumgegevens (concurrente validiteit). Vaak is er gebruik gemaakt van de Youth Self Report (YSR, zelfrapportage) of Child Behavior Checklist (CBCL, ouder) als gouden standaard (Achenbach et al., 2001). Beide vragenlijsten maken deel uit van het 'Achenbach System of Empirically Based Assessment' oftewel ASEBA. De YSR en CBCL zijn bewezen goede gevalideerde vragenlijsten voor het meten van gedrag en emotionele problemen.

Sommige JGZ-organisaties gebruiken de Jij en Je Gezondheid werkwijze [http://www.jijenjegezondheidinfo.nl/?page=jij-en-je-gezondheid]. Jij en je gezondheid is een werkwijze waarmee leerlingen vanaf 12 jaar met risicogedragingen actief worden opgespoord, ondersteund en zo nodig toegeleid naar veelbelovende en effectieve (preventie)programma's. Er wordt hierbij gebruik gemaakt van online vragenlijsten die door de leerling worden ingevuld, zoals Revised Child Anxiety and Depression Scale (RACDS-25) voor de signalering van angst en depressie en de Ask Suicide-screening Questions (ASQ) voor het meten van risico op suïcide en de Adolescent Psychotic Symptom Screener (APSS) voor het meten van psychotische klachten. Deze instrumenten richten zich niet op psychosociale problemen, maar op DSM-5 gerelateerde problemen.

\section{SDQ kindversie en KIVPA}

De psychometrische kenmerken van de SDQ bij 13 en 14 jarigen zijn in onderzoek vergeleken met de KIVPA (Vogels et al., 2011). De resultaten laten zien dat de SDQ kindversie en de KIVPA wat betreft validiteit vergelijkbare instrumenten zijn. De overeenkomst van beide instrumenten met de Youth Self-report, de kindversie van de $C B C L$ is hoog. Ook kunnen beide signaleringslijsten de signalering van psychosociale problemen door de JGZ medewerker verbeteren (Vogels et al., 2011). 
De SDQ kindversie heeft de voorkeur voor gebruik in de JGZ in vergelijking met de KIVPA bij 13-14 jarigen. Beide instrumenten hebben een goede validiteit, maar SDQ kindversie sluit aan bij het gebruik van de SDQ ouderversie in groep 7 van de basisonderwijs en bij het gebruik van de SDQ in de jeugdhulpsector.

Voor de overige leeftijden (15-18 jaar) is de validiteit van de kindversie van de SDQ en de KIVPA nog niet onderzocht in een Nederlandse setting. Er is wel aangetoond dat de factorstructuur van de Nederlandse SDQ kindversie bij 11-16 jarigen goed is (van de Looij-Jansen et al., 2011).

\subsubsection{Meerwaarde van de SDQ ouderversie naast afname van de SDQ kindversie}

In de JGZ wordt vaak de SDQ kindversie afgenomen, en niet de SDQ ouderversie bij kinderen van 12 jaar en ouder. Onderzoek laat zien dat het afnemen van de SDQ ouderversie naast de SDQ kindversie een duidelijke meerwaarde heeft(Vogels et al., 2011).

\subsubsection{Hoe en wanneer de vroegsignaleringslijsten te gebruiken?}

Tabel 1 geeft een overzicht van de aanbevolen signaleringslijsten voor vroegsignalering. Ook wordt in deze tabel een link gegeven naar de beschikbare handleidingen. De SDQ handleiding voor de JGZ is gericht op de SDQ bij 3-17 jarigen (Theunissen et al., 2016). Voor de BITSEA wordt een handleiding beschikbaar gesteld voor de JGZ in 2016 (ZonMw) [LINK

http://www.zonmw.nl/nl/projecten/project-detail/implementatie-van-de-brief-infant-toddler-soci al-emotional-assessment-bitsea-in-de-jgz/samenvatting/].

Het wordt aanbevolen om op alle leeftijden (0-4 jaar, 4-7 jaar, 8-12 jaar, 13-14 jaar) een instrument te gebruiken. Deze aanbeveling sluit aan bij de oude JGZ-richtlijn psychosociale problemen (Postma, 2008). Op dit moment zijn er echter nog geen onderzoeksresultaten beschikbaar die aangeven of het noodzakelijk is om op al deze leeftijden een vragenlijst af te nemen voor de vroegsignalering van psychosociale problemen. Vanwege weerstand van ouders bij het invullen van vragenlijsten heeft men de voorkeur om het gebruik van vragenlijsten zoveel mogelijk terug te brengen. Maar om hieraan tegemoet te komen moet eerst worden onderzocht of met het minder vaak afnemen van vragenlijsten even effectief psychosociale problemen kan worden opgespoord. Erasmus MC voert een onderzoek uit naar de effectiviteit van herhaalde afname van psychosociale vragenlijsten in de JGZ, de resultaten zijn bekend in 2017 (zie ZonMw) [LINK

http://www.zonmw.nl/nl/projecten/project-detail/mag-het-ietsje-minder-zijn-het-terugdringen-v an-de-vragenlijstdruk-bij-het-signaleren-van-psychosoc/samenvatting/].

Tabel 1 Vroegsignalering in de Jeugdgezondheidszorg: aanbevolen instrumenten

\begin{tabular}{|c|c|c|c|c|c|}
\hline Leeftijd & Soort instrument & Doel & Bron & Validiteit & $\begin{array}{l}\text { Beschikbare } \\
\text { handleiding }\end{array}$ \\
\hline 0-4 jaar & $\begin{array}{l}\text { DMO-protocol } \\
\text { (gespreksprotocol } \\
\text { Samen Starten)(voor } \\
\text { kinderen van 0-4 jaar ) }\end{array}$ & $\begin{array}{l}\text { Risico-inventarisatie } \\
\text { (ontwikkeling en } \\
\text { zorgwekkende } \\
\text { opvoedingssituaties), } \\
\text { domeinen: } \\
\text { - competentie ouder } \\
\text { - rol partner } \\
\text { - sociale steun } \\
\text { - obstakels } \\
\text { - welbevinden kind }\end{array}$ & $\begin{array}{l}\text { Ouders/ } \\
\text { verzorgers }\end{array}$ & $\begin{array}{l}\text { Effectiviteit is onderzocht voor } \\
0 \text {-18 maanden. Effectief in het } \\
\text { signaleren van risico's van } \\
\text { psychosociale problematiek. } \\
\text { Maar werken met } \\
\text { DMO-protocol kan niet } \\
\text { psychosociaal welbevinden van } \\
\text { kinderen verbeteren }\end{array}$ & \\
\hline
\end{tabular}




\begin{tabular}{|c|c|c|c|c|c|}
\hline 0-4 jaar & $\begin{array}{l}\text { SPARK (voor kinderen } \\
\text { van } 18 \text { maanden) }\end{array}$ & $\begin{array}{l}\text { Inventarisatie van } \\
\text { behoefte aan } \\
\text { opvoedingsondersteuning. }\end{array}$ & $\begin{array}{l}\text { Ouders/ } \\
\text { verzorgers }\end{array}$ & $\begin{array}{l}\text { Gevalideerd voor } 18 \text { maanden. } \\
\text { Convergente validiteit is matig. } \\
\text { Predictieve validiteit is goed. } \\
\text { Criterium validiteit niet } \\
\text { onderzocht. }\end{array}$ & \\
\hline 0-4 jaar & $\begin{array}{l}\text { BITSEA (voor } \\
\text { kinderen van } 12 \\
\text { tot } 36 \text { maanden) }\end{array}$ & $\begin{array}{l}\text { Vragenlijst m.b.t. } \\
\text { gedrag, emoties, } \\
\text { sociale interacties } \\
\text { en indicatoren voor } \\
\text { psychopathologie } \\
\text { zodat vroegtijdig } \\
\text { externaliserende } \\
\text { en internaliserende } \\
\text { problemen worden } \\
\text { gesignaleerd. }\end{array}$ & $\begin{array}{l}\text { Ouders/ } \\
\text { verzorgers }\end{array}$ & $\begin{array}{l}\text { Valide voor de leeftijdsgroep } 24 \\
\text { maanden }\end{array}$ & $\begin{array}{l}\text { In } 2016 \text { wordt } \\
\text { een handleiding } \\
\text { voor de JGZ } \\
\text { beschikbaar } \\
\text { gesteld (ZonMw) }\end{array}$ \\
\hline 0-4 jaar & SDQ (vanaf 3) & $\begin{array}{l}\text { Emotionele problemen, } \\
\text { gedragsproblemen, } \\
\text { hyperactiviteit } \\
\text { en problemen met } \\
\text { leeftijdsgenoten }\end{array}$ & $\begin{array}{l}\text { Ouders/ } \\
\text { verzorgers }\end{array}$ & Valide bij 3-4 jarigen & $\begin{array}{l}\text { Handleiding voor } \\
\text { het gebruik van } \\
\text { de SDQ in de } \\
\text { JGZ } \\
\text { https://www.ggd } \\
\text { ghorkennisnet.nl } \\
\text { ?file }=30697 \& m \\
=1477564280 \& \text { a } \\
\text { ction=file.downl } \\
\text { oad }\end{array}$ \\
\hline 4-7 jaar & SDQ & $\begin{array}{l}\text { Emotionele problemen, } \\
\text { gedragsproblemen, } \\
\text { hyperactiviteit } \\
\text { en problemen met } \\
\text { leeftijdsgenoten. }\end{array}$ & $\begin{array}{l}\text { Ouders/ } \\
\text { Verzorgers } \\
\text { en } \\
\text { leerkracht }\end{array}$ & Valide bij 4-7 jarigen & $\begin{array}{l}\text { Handleiding voor } \\
\text { het gebruik van } \\
\text { de SDQ in de } \\
\text { JGZ } \\
\text { https://www.ggd } \\
\text { ghorkennisnet.nl } \\
\text { ?file }=30697 \& \mathrm{~m} \\
=1477564280 \& \mathrm{a} \\
\text { ction=file.downl } \\
\text { oad }\end{array}$ \\
\hline 8-12 jaar & SDQ & $\begin{array}{l}\text { Emotionele problemen, } \\
\text { gedragsproblemen, } \\
\text { hyperactiviteit } \\
\text { en problemen met } \\
\text { leeftijdsgenoten. }\end{array}$ & $\begin{array}{l}\text { Ouders/ } \\
\text { verzorgers }\end{array}$ & Valide bij 7-11 jarigen & $\begin{array}{l}\text { Handleiding voor } \\
\text { het gebruik van } \\
\text { de SDQ in de } \\
\text { JGZ } \\
\frac{\text { https://www.ggd }}{\text { ghorkennisnet.nl }} \\
\text { ?file=30697\&m } \\
\frac{=1477564280 \& \text { a }}{} \\
\underline{\text { ction=file.downl }} \\
\text { oad }\end{array}$ \\
\hline 13-14 jaar & SDQ & $\begin{array}{l}\text { Emotionele problemen, } \\
\text { gedragsproblemen, } \\
\text { hyperactiviteit } \\
\text { en problemen met } \\
\text { leeftijdsgenoten }\end{array}$ & $\begin{array}{l}\text { Jeugdigen en } \\
\text { Ouders/verz } \\
\text { orgers }\end{array}$ & Valide voor $13-14$ jarigen & $\begin{array}{l}\text { Handleiding voor } \\
\text { het gebruik van } \\
\text { de SDQ in de } \\
\text { JGZ } \\
\text { https://www.ggd } \\
\text { ghorkennisnet.nl } \\
\text { ?file }=30697 \& m \\
=1477564280 \& a\end{array}$ \\
\hline
\end{tabular}




\begin{tabular}{|c|c|c|c|c|c|}
\hline & KIVPA & Psychosociale problemen & Jeugdigen & Valide voor 13-14 jarigen & $\begin{array}{l}\frac{\text { ction=file.downl }}{\text { oad }} \\
\text { http://mijn.qind. } \\
\begin{array}{l}\text { nl/userfiles/192/ } \\
\text { File/Handleiding } \\
\text { KIVPA.pdf }\end{array}\end{array}$ \\
\hline $15-16$ jaar & SDQ & $\begin{array}{l}\text { Emotionele problemen, } \\
\text { gedragsproblemen, } \\
\text { hyperactiviteit } \\
\text { en problemen met } \\
\text { leeftijdsgenoten. }\end{array}$ & $\begin{array}{l}\text { Jeugdigen en } \\
\text { ouders/verz } \\
\text { orgers }\end{array}$ & $\begin{array}{l}\text { Veelbelovend instrument, maar } \\
\text { nog niet gevalideerd voor deze } \\
\text { leeftijdsgroep }\end{array}$ & $\begin{array}{l}\text { Handleiding voor } \\
\text { het gebruik van } \\
\text { de SDQ in de } \\
\text { JGZ } \\
\text { https://www.ggd } \\
\text { ghorkennisnet.nl } \\
\text { ?file }=30697 \& m \\
=1477564280 \& \text { a } \\
\text { ction=file.downl } \\
\text { oad }\end{array}$ \\
\hline
\end{tabular}

\subsection{Diagnostische instrumenten}

Op basis van de uitkomsten van de signalering kan het nodig zijn voor nadere diagnostiek uitgebreidere generiek signaleringsinstrumenten te gebruiken, zoals één van de Achenbach System of Empirically Based Assessment (ASEBA) vragenlijsten. Deze lijsten kunnen door ouders of verzorgers (de Child Behavior Check List, CBCL), leerkrachten (Teacher Report Form, TRF) of door het kind zelf (Youth Self Report, YSR) ingevuld worden. Deze lijsten zijn door hun lengte niet standaard te gebruiken in de JGZ. Zij zijn wel gevalideerd en genormeerd en daarbij geschikt als assessment instrument, als nadere stap van probleemverkenning na gebruik van bijvoorbeeld de SDQ (Klein Velderman et al., 2007).

In het schema richtinggevende diagnostiek (NCJ) wordt aangegeven welke diagnostische instrumenten ingezet kunnen worden bij een vermoeden van bijv. angst, ADHD, autisme spectrum stoornis, depressie.

\section{Referenties}

Achenbach T, Rescorla L. Manual for the ASEBA School-Age Froms \& Profiles. Burlington: University of Vermont; 2001.

Brugman E, Reijneveld SA, Verhulst FC, Verloove-Vanhorick SP. Identification and management of psychosocial problems by preventive child health care. Arch Pediatr Adolesc Med. 2001;155(4):462-469.

Crone MR, Bekkema N, Wiefferink CH, Reijneveld SA. Professional identification of psychosocial problems among children from ethnic minority groups: Room for improvement. J Pediatr. 2010;156(2):277-284.

GGD Nederland (2006). Handleiding voor het gebruik van de SDQ binnen de Jeugdgezondheidszorg.

Vragenlijst voor het signaleren van psychosociale problemen bij kinderen van 7-12 jaar. www.ggdkennisnet.nl 
Harmsen $H$, Meeuwesen L, van Wieringen J, Bernsen R, Bruijnzeels $M$. When cultures meet in general practice: intercultural differences between GPs and parents of child patients. Patient Educ Couns 2003;51: 99-106.

Hermanns, J., F. Öry, G. Schrijvers, m.m.v. M. Junger en M. Blom (2005). Helpen bij opgroeien en opvoeden: eerder, sneller en beter. Een advies over vroegtijdige signalering en interventies bij opvoed- en opgroeiproblemen. Utrecht: Inventgroep (www.integratedcare.nl).

Hielkema, M (2015). The value of a family-centered approach in Preventive Child Healthcare Monitoring the social-emotional development of infants. Proefschrift. Groningen: UMCG, Rijksuniversiteit Groningen.

Klein Velderman M, Crone MR, Wiefferink $\mathrm{CH}$, Reijneveld SA. Identification and management of psychosocial problems among toddlers by preventive child health care professionals. Eur J Public Health. 2010;20(3):332-338.

Klein Velderman, M., C.M.H. Hosman, T.G.W.M. Paulussen (2007). Onderzoeksprogrammering Opvoed- en opgroeiondersteuning. Leiden: TNO Kwaliteit van Leven.

Kruizinga I (2015). Early detection of emotinal and behavioural problems in preschool children. The use of the Brief infant-toddler social and emtional assessment in preventive child health care. Proefschrift. Rotterdam: Erasmus Universiteit Rotterdam.

Kruizinga I, Jansen W, de Haan CL, van der Ende J, Carter AS, et al. (2012a) Reliability and Validity of the Dutch Version of the Brief Infant-Toddler Social and Emotional Assessment (BITSEA). PLoS ONE 7(6): e38762.

Kruizinga I, Jansen W, de Haan CL, Raat H (2012b) Reliability and Validity of the KIPPPI: An Early Detection Tool for Psychosocial Problems in Toddlers. PLoS ONE 7(11): e49633.

Meeuwesen L, Harmsen JA, Bernsen RM, Bruijnzeels MA. Do Dutch doctors communicate differently with immigrant patients than with Dutch patients? Soc Sci Med 2006;63:2407-17.

Middleton KL, Jones JL. Socially desirable response sets: the impact of country culture. Psychology \& Marketing 2000;17:149-63.

Mieloo C (2015). Early detection and referral of young children with psychosocial problems in the preventive child health care. An evaluation of the use of the strengths and difficulties questionnaire. Proefschrift. Rotterdam: Erasmus Universiteit Rotterdam.

Nederlands Centrum Jeugdgezondheidszorg. Verantwoord gebruik van vragenlijsten in de jeugdgezondheidszorg. NCJ-Nederlands Centrum Jeugdgezondheid. Utrecht; 2013.

Postma . JGZ-richtlijn vroegsignalering van psychosociale problemen. RIVM, Centrum Jeugdgezondheid, Bilthoven:2008.

Reijneveld SA, Brugman E, Verhulst FC, Verloove-Vanhorick SP. Identification and management of psychosocial problems among toddlers in dutch preventive child health care. Arch Pediatr Adolesc Med. 2004;158(8):811-817.

Sheldrick RC, Merchant S, Perrin EC. Identification of developmental-behavioral problems in primary care: A systematic review. Pediatrics. 2011;128(2):356-363.

Staal, I.I.E., Hermanns, J.A.M., Schrijvers, A.J.P., \& Stel, H.F. van (2013). Risk assessment of parents concerns at 18 months in preventive child health care predicted child abuse and neglect. Child Abuse\& Neglect, 37, 475-484

Stel, H.F. van, Staal, I.I.E., Hermanns, J.A.M., \& Schrijvers, A.J.P. (2012). Validity and reliability of a structured interview for early detection and risk assessment of parenting and developmental problems in young children: a cross-sectional study. BMC Pediatrics, 12, 71

Stone, LL. (2014). Measuring up: perspectives on psychometrics and contextual factors of early childhood problems. Nijmegen: Radboud Universiteit Nijmegen.

Theunissen MHC, Wolff de M, Grieken van A, Mieloo C. (2016). Handleiding voor het gebruik van de SDQ binnen de Jeugdgezondheidszorg. Vragenlijst voor het signalering van psychosociale problemen bij 3-17 jarigen. TNO, Leiden. 
Theunissen MHC (2013). The early detection of psychosocial problems in children aged 0 to 6 years by Dutch preventive child healthcare: professionals and their tools. Proefschrift. Leiden: TNO.

Theunissen MH, Vogels AG, Reijneveld SA. Early detection of psychosocial problems in children aged 5 to 6 years by preventive child healthcare: Has it improved? J Pediatr. 2012;160(3):500-504.

Theunissen M, Vogels A, de Wolff M, Reijneveld SA. Characteristics of the Strengths and

Difficulties Questionnaire in Pre-school Children. Pediatrics 2013a, 131 (2):1-9.

Theunissen MHC, Lijster de GPA., Wilde de JA., Kocken PL. Signaleren in de JGZ: Ontwikkeling en bruikbaarheid van een standaard vragenlijst ten behoeve van het preventief gezondheidsonderzoek 5-6 en 10-11 jarigen. TSG 2013b, 91(7), 415-421.

Theunissen MHC, Vogels AGC, Wolff de MS, Crone MR, Reijneveld SA. Comparing three short questionnaires to detect psychosocial problems among 3 to 4 -year olds. BMC pediatrics 2015, 15:84.

Theunissen MHC, , Wolff de MS, Vogels AGC, Reijneveld SA. Het opsporen van psychosociale problemen bij kinderen in de leeftijd van nul tot en met zes jaar door de jeugdgezondheidszorg. TJGZ 2014, 46 (3), 46-50.

van de Looij-Jansen PM, Goedhart AW, de Wilde EJ, Treffers PD. Confirmatory factor analysis and factorial invariance analysis of the adolescent self-report strengths and difficulties questionnaire: How important are method effects and minor factors? $\mathrm{Br} J$ Clin Psychol. 2011;50(2):127-144.

Vink RM, Rijnders MEB, Dommelen van $\mathrm{P}$, Broerse A. Vroeg signaleren van ongunstige opgroei-omstandigheden door verloskundigen in Zaanstad en Amsterdam-Noord. Leiden: TNO Kwaliteit van Leven, 2009

Vink, R., Rijnders, M., Buitendijk, S., Broerse, A. Korfker, D., Öry, F. (2010) Vroeg erbij. Vroegsignalering met de ALPHA-NL. Tijdschrift voor verloskundigen. KNOV. April 2010.

Vogels, A.G.C. (2008). The Identification by Dutch Preventive Child Health Care of Children with Psychosocial Problems: Do Short Questionnaires Help? Proefschrift. Leiden: TNO.

Vogels AG, Jacobusse GW, Hoekstra F, Brugman E, Crone M, Reijneveld SA. Identification of children with psychosocial problems differed between preventive child health care professionals. J Clin Epidemiol. 2008b;61(11):1144-1151.

Vogels AG, Crone MR, Hoekstra F, Reijneveld SA. Comparing three short questionnaires to detect psychosocial dysfunction among primary school children: A randomized method. BMC Public Health. 2009;9(1):489.

Vogels, T., S.A Reijneveld, E. Brugman, M. den Hollander-Gijsman, F.C. Verhulst, S.P. Verloove-Vanhorick (2003). Detecting psychosocial problems among 5-6 year old children in Preventive Child Health Care. European Journal of Public Health, 13, 353-360.

Vogels AGC, Hilgersom MJC, Theunissen MHC, de Wolff MS, Reijneveld SA, eds. Pilot implementatie en validatie van de PSYCAT in de Jeugdgezondheidszorg. Leiden: TNO Kwaliteit van leven; 2010.

Vogels AGC, Jacobusse GW , Reijneveld SA. An accurate and efficient identification of children with psychosocial problems by means of computerized adaptive testing. BMC Medical Research Methodology 2011, 11:111.

Vogels AGC, Siebelink BM, Theunissen MHC. de Wolff MS, Reijneveld SA (2011). Vergelijking van de KIVPA en de SDQ als signaleringsinstrument voor problemen bij adolescenten in de Jeugdgezondheidszorg. Leiden: TNO.

Wagenaar-Fischer, M.M., N. Heerdink- Obenhuijsen, M. Kamphuis, J. de Wilde (2007). JGZ Richtlijn Secundaire Preventie Kindermishandeling. Handelen bij een 
vermoeden van kindermishandeling. 2007.

Wolff de MS, Theunissen MHC, Vogels AGC, Reijneveld SA. Three questionnaires to detect psychosocial problems in toddlers: A comparison of the BITSEA, ASQ:SE and KIPPPI. Academic Pediatrics 2013;13:587-592.

ZonMw (2013). Programmeringsstudie. 


\section{Thema 3 Advisering en interventies bij psychosociale problemen}

\section{Inleiding}

In dit thema wordt ingegaan op de algemene handelingen die de JGZ kan toepassen bij een vermoeden van een psychosociaal probleem. Vervolgens worden de werkzame elementen besproken van effectieve interventies bij psychosociale problemen, deze elementen kunnen als basis dienen voor advisering door de JGZ. Tenslotte worden de effectieve interventies weergegeven die door de JGZ kunnen worden ingezet, en we geven aan waarheen de JGZ naar kan verwijzen. Er wordt een onderscheid gemaakt naar emotionele, gedrag en sociale problemen (conform de definitie van psychosociale problemen). Dit thema richt zich op de domeinen ouders, jeugdigen en school.

\section{Aanbevelingen}

\subsection{Algemeen handelen bij psychosociale problemen}

De volgende algemene handelingen worden aanbevolen uit te voeren bij een (vermoeden) van een psychosociaal probleem.

- Werk volgens de NCJ handreiking 'Aansluiten bij de ouders van vandaag'. Wees duidelijk, toon betrokkenheid, sta naast de cliënt, wees betrouwbaar, sluit aan bij de cliënt, heb respect, zorg voor een goed contact en geef positieve feedback.

(Zie onderbouwing 4.1.1 Professionele houding)

- Werk volgens de NCJ handreiking 'De kracht van zelfregie'. Gebruik bij de interactie met kinderen en ouders benaderingen als shared decision making, motiverende gespreksvoering en oplossingsgericht werken.

(Zie onderbouwing 4.1.2 Interactie met ouders en kinderen)

- Biedt ondersteuning aan scholen bij het uitvoeren van passend onderwijs. Zoals advisering rondom collectieve gezondheidszorg en gezonde school en het verstrekken van handelings- en omgevingsgerichte adviezen aan leerkrachten en ouders. Zie informatie brochure NCJ 'Onderwijs en Jeugdgezondheidszorg: van oudsher partners' . (Zie onderbouwing 4.1.3 Ondersteuning aan scholen bij het uitvoeren van passend onderwijs)

De volgende algemene handelingen kunnen worden overwogen om in te zetten bij een vermoeden van een psychosociaal probleem.

- Stimuleer de betrokkenheid van het sociale netwerk van de ouder(s) en jeugdigen bij de opvoeding van de jeugdige. Denk aan buren, grootouders, ouders van vriendjes, of ouders van de sportclub.

- Concreet kan daarbij worden gedacht aan ook door de JGZ uitgevoerde interventies als MIM ('Moeders Informeren Moeders'), Home Start, de Opvoedparty, allerlei vormen van lotgenotencontact en ontmoetingsmogelijkheden, zoals (digitale) vader- en moedergroepen, themabijeenkomsten, ouderavonden over actuele onderwerpen.

(Zie onderbouwing 4.143 Het activeren van de directe omgeving van ouders en jeugdigen)

>Praktijk-gebaseerde aanbeveling, gebaseerd op NCJ handreiking en NJI Wat-Werkt databank.

\subsection{Adviezen om psychosociale ontwikkeling te stimuleren}

- Wees bekend met werkzame elementen uit bestaande effectieve interventies rondom gedrag, emotionele en sociale problemen vanuit de documenten uit de NJI Wat-Werkt 
Databank (http://www.nji.nl/nl/Databank/Databank-Wat-werkt) . Deze elementen kunnen als basis dienen voor advisering aan ouders en jeugdigen.

- Wees bekend met de aanbevelingen rondom advisering zoals beschreven in andere JGZ richtlijnen (bijvoorbeeld angst, depressie, ADHD, autisme spectrum stoornis en opvoedingsondersteuning) .

(Voor een nadere toelichting welke adviezen gegeven kunnen worden ter preventie van emotionele, gedrags- en sociale problemen, zie onderbouwing 4.2 Adviezen om de psychosociale ontwikkeling van het kind te stimuleren)

>Praktijk-gebaseerde aanbeveling, gebaseerd op NJI Wat-Werkt databank NJI en diverse bestaande JGZ -richtlijnen (die beiden deels gebaseerd zijn op wetenschappelijk bewijs).

\subsection{Bewezen effectieve interventies bij psychosociale problemen}

- Wanneer meer hulp nodig is dan alleen advisering door de JGZ, verwijs dan een jeugdige met psychosociale problemen naar een interventie die volgens de $\mathrm{NJI}$ databank Effectieve Jeugdinterventies geclassificeerd is als goed onderbouwd, effectief volgens eerste aanwijzingen of effectief volgens goede aanwijzingen. (zie Tabel 1)).

- Wees goed op de hoogte van het lokale aanbod, de lokale route richting zorg bij psychosociale problemen en ben op de hoogte of een kind past in een voor die doelgroep effectieve interventie. Alleen dan kan elk kind de meeste adequate zorg voor psychosociale problemen krijgen.

$>$ Gebaseerd op wetenschappelijk bewijs, gebaseerd op NJI Databank Effectieve Jeugdinterventies, en deels praktijk gebaseerd of goed onderbouwd.

\section{Uitgangsvragen}

- Algemeen handelen bij psychosociale problemen: Wat kunnen JGZ-professionals altijd in het algemeen doen bij psychosociale problemen?

- Adviezen om psychosociale ontwikkeling te stimuleren: Wat zijn collectieve en individuele preventieve adviezen aan ouders en de omgeving van het kind om de psychosociale ontwikkeling van het kind te stimuleren?

- Effectieve interventies bij psychosociale problemen: Wat zijn (bewezen effectieve) interventies die de JGZ-professionals kunnen toepassen bij psychosociale problemen?

\section{Onderbouwing}

\subsection{Algemeen handelen bij psychosociale problemen}

De uitgangsvraag die beantwoord gaat worden, is: "Wat kunnen JGZ-professionals in het algemeen doen bij psychosociale problemen?" Behalve interveniëren en adviseren kunnen JGZ-professionals nog veel meer doen voor en met ouders en jeugdigen. Ze staan eigenlijk nooit met lege handen. Vanuit verschillende bronnen worden mogelijkheden aangereikt, die te maken hebben met verschillende invloedsferen van professionals, te weten:

1. Professionele houding

2. De interactie met kinderen en ouders

3. School ondersteuning bieden bij de uitvoering van passend onderwijs

4. Het activeren van de directe omgeving van ouders en jeugdigen

Onderstaand wordt elk punt nader uitgewerkt. 


\subsubsection{Professionele houding}

JGZ-professionals kunnen ouders en jeugdigen stimuleren actief te werken aan de eigen oplossingen van problemen en uitnodigen actief te participeren in preventie en hulp. Dat wil zeggen: als ouders een vraag of probleem m.b.t. de psychosociale ontwikkeling van hun kind voorleggen; luister vooral heel goed, vraag na wat de ouder zelf ervan denkt en wat hij/zij al gedaan heeft en nodig de ouder uit om andere oplossingen te bedenken. Benadruk daarbij de deskundigheid van de ouders; en koppel terug wat je als professional opvalt of waarneemt. Daarbij past een wijze van bejegening, zoals die in de 'Handreiking Aansluiten bij de ouders van $v_{\text {vandaag }}$ (NCJ, 2012) is aangereikt. De Handreiking is mede gebaseerd op procesmatige factoren die de blijvende en actieve participatie van ouders en jeugdigen bevorderen (Ince, 2013; Watson e.a. 2005):

- Wees duidelijk: handel transparant, luister en reageer empathisch, geef goede informatie, hanteer heldere taal, koppel regelmatig terug, wees eerlijk en evalueer regelmatig;

- Toon betrokkenheid: toon interesse, warmte, acceptatie en toon inzet. Wees beschikbaar en bereikbaar;

- Sta naast de cliënt: zorg voor gelijkwaardigheid, werk samen, activeer de cliënt en leg de regie bij de cliënt;

- Wees betrouwbaar: kom afspraken na, waarborg de privacy;

- Sluit aan bij de cliënt: ga uit van de hulpvraag van de cliënt, ga uit van de mogelijkheden van de cliënt en zijn omgeving;

- Heb respect: accepteer de persoon zoals hij is, neem de cliënt serieus;

- Zorg voor een goed contact: wees mens en zorg voor een goede sfeer;

- Geef positieve feedback: geef op een positieve manier aanwijzingen, geef complimenten en moedig het nemen van risico's aan.

\subsubsection{De interactie met kinderen en ouders}

Ouders zijn de eerst verantwoordelijken voor de opvoeding van hun kind(eren). Als ouders eerlijk kunnen reflecteren op het eigen handelen, dan betekent dit een sterke beschermende factor (buffer). Ouders vormen een belangrijke voorbeeldfunctie voor kinderen.

Het proces van mentaliseren - even buiten jezelf tredend de situatie beschouwen - kan goed door de JGZ worden begeleid vanuit haar vertrouwenspositie en het vermogen 'naast de ouder te staan'. Dus nodig de ouders uit om te reflecteren op zichzelf en op hun eigen opvoedgedrag in relatie tot het kind. Als een ouder het moeilijk vindt om van een afstand naar zichzelf te kijken, dan kan het helpen als de JGZ professional hardop verwoordt wat de professional ziet en welke gedachten dat oproept.

Het toeleiden naar zorg is een gezamenlijk proces tussen professional en ouder(s) en/of jeugdige. Het start met het bespreken van vragen, wensen of zorgen met ouders en jeugdigen, waarna met elkaar wordt verkend wat er nodig is om de gezondheidssituatie te verbeteren. Belangrijke uitgangspunten om samen te komen tot passende hulp staat beschreven in de NCJ handreiking 'De kracht van de zelfregie' (Heerwaarden \& Pijpers, 2015) . Deze uitgangspunten worden beschreven in Thema 4: samenwerking .

Studies over beslissen bij hulp geven ook aanwijzingen over de interactie tussen de JGZ en kinderen en ouders "Alleen als ouders en jeugdige het gevoel hebben dat je hun vraag hoort en serieus neemt, heb je een basis om verder samen te werken" (Bartelink, ten Berge \& van Yperen, 2013).

Benaderingen als 'shared decision making, motiverende gespreksvoering en oplossingsgericht werken helpen bij het proces van effectief beslissen over hulp in dialoog. Zie voor meer informatie hierover de publicaties 'Beslissen over effectieve hulp' (Bartelink et al., 2013); 'Wat werkt: 
oplossingsgerichte therapie' (Bartelink, 2013a) en 'Wat werkt: motiverende gespreksvoering' (Bartelink, 2013b) in de NJI Wat-Werkt Databank .

\subsubsection{Biedt ondersteuning aan scholen bij de uitvoering van passend onderwijs}

Scholen hebben de plicht om passend onderwijs te bieden dit betekent dat alle kinderen een zo passend mogelijke plek in het onderwijs krijgen, ongeacht hun extra zorgbehoefte. Ook hebben scholen een zorgplicht. Dit betekent dat kinderen recht hebben op een passende onderwijsplek op de eigen of een andere school. Het weigeren of verwijderen van kinderen vanwege hun ondersteuningsbehoefte mag niet. Eerst moet er een passende plek op een andere school zijn geregeld.

Voor de JGZ is het zaak om met haar ondersteuning aan te sluiten bij het onderwijs. Essentieel voor scholen is dat zij in het kader van Passend Onderwijs, het onderwijs en de ondersteuning zo aanbieden, dat leerlingen het onderwijsprogramma zo goed mogelijk kunnen doorlopen. Dit vraagt naast een positief schoolklimaat ook een optimaal functionerend ondersteuningssysteem op school.

Samenwerking tussen onderwijs, JGZ, zorgaanbieders, hulpverleners, politie en justitie ligt aan de basis van het leveren van deze ondersteuning. Met goede samenwerking is de school niet alleen een vindplaats, maar wordt deze ook daadwerkelijk een actieplaats. De JGZ kan scholen adviseren rond de collectieve gezondheidszorg en gezonde school. Steeds vaker gebruiken scholen speciaal ontwikkelde screeningsmethoden. Voorbeelden zijn de sites Gezond leven check het even! en Jij en je gezondheid, en het online magazine over het extra contactmoment voor adolescenten. Anderzijds kan de JGZ verstrekken van handelings- en omgevingsgerichte adviezen aan leerkrachten, ouders, jeugdigen en kernpartners. Persoonlijke gesprekken en psycho-educatie zijn hier onderdeel van

(Pijpers, Bouma, Beckers \& Boode, 2013).

\subsubsection{Het activeren van de directe omgeving van ouders en jeugdigen.}

Het netwerk en de sociale omgeving van ouders en jeugdigen kan een belangrijke beschermende factor vormen bij (het voorkómen en verminderen van) psychosociale problemen. Denk aan buren, grootouders, ouders van vriendjes, of andere ouders van de sportclub. Activering van het ondersteunende potentieel van die omgeving is in dat verband een preventieve aanpak, die aansluit bij de doelstellingen van de JGZ. Drie vormen van betrokkenheid van burgers bij de opvoeding van jeugdigen kunnen worden gestimuleerd door de JGZ:

- Informele steun, op deze steun kunnen ouders terugvallen wanneer dit nodig is. Deze steun bestaat uit emotionele ondersteuning door bijvoorbeeld een luisterend oor te bieden, opvoedondersteuning door ervaringen uit te wisselen en elkaar te adviseren, en ook uit praktische ondersteuning, zoals oppassen.

- Informele sociale controle, wanneer de inwoners van een wijk elkaar goed kennen en er sprake is van een gedeelde sociale norm is het gemakkelijker en gebruikelijker om elkaar aan te spreken op ieders gedrag.

- Intergenerationeel contact, dit contact vindt plaats tussen volwassenen en jeugdigen. Volwassenen zijn rolmodellen voor jeugdigen en hebben een belangrijke rol in het bevorderen van een positieve ontwikkeling. Deze volwassen zijn buurtbewoners, leerkrachten, familieleden en bijvoorbeeld de sportcoach (Gemmeke, 2011).

Voorbeelden van door de JGZ uitgevoerde interventies waarbij de betrokkenheid van het sociale netwerk bij de opvoeding van jeugdigen wordt gestimuleerd zijn MIM ('Moeders Informeren Moeders'), Home Start, de Opvoedparty, allerlei vormen van lotgenotencontact en 
ontmoetingsmogelijkheden, zoals (digitale) vader- en moedergroepen , themabijeenkomsten, ouderavonden over actuele onderwerpen. Voor meer voorbeelden zie:

www.allemaalopvoeders.nl.

\subsection{Adviezen om de psychosociale ontwikkeling van het kind te stimuleren}

De uitgangsvraag die onderstaand beantwoord wordt, is: "Wat zijn collectieve en individuele preventieve adviezen aan ouders en de omgeving van het kind om de psychosociale ontwikkeling van het kind te stimuleren?".

Ince, Van Yperen en Valkestijn (2013) hebben uiteengezet wat de belangrijkste factoren zijn die een bijdrage leveren aan een voorspoedige ontwikkeling van kinderen en jongeren en hoe interventies hierop in kunnen spelen. Zij onderscheiden factoren als het versterken van de sociale binding, vergroten van kansen voor betrokkenheid, erkenning en waardering voor positief gedrag en het bevorderen van (sociale, emotionele en gedragsmatige) competenties. Meer informatie is te vinden in het rapport 'Wat werkt bij het bevorderen van een positieve ontwikkeling van jeugdigen' (Daamen en Ince, 2014) en in het rapport 'Top tien positieve ontwikkeling jeugd' (Ince, van Yperen en Valkestijn, 2013), beide te vinden op de NJI website .

Indien ouders vragen hebben over het gedrag van hun kind (bijvoorbeeld over de omgang met vrienden, vrijetijdsbesteding, gedrag op school, eten, slapen of mediagebruik) is het belangrijk om te bekijken of er sprake is van een (psychosociaal) probleem. Vaak willen ouders alleen hun zorgen delen, en samen met een professional mogelijke oplossingen bespreken. Normaliseren is daarbij belangrijk, waarbij de JGZ-professional informatie geeft over gangbare, normale problemen bij kinderen en jongeren, zonder dat meteen adviezen worden gegeven. Een tabel met voorbeelden van normale problemen is opgenomen in de JGZ-richtlijn Opvoedingsondersteuning .

Bij advisering rondom psychosociale problemen is het van belang om bekend te zijn met de werkzame elementen uit bestaande effectieve interventies rondom gedrag, emotionele en sociale problemen vanuit de documenten uit de Wat Werkt Databank en bekend te zijn met aanbevelingen rondom advisering zoals beschreven in andere JGZ richtlijnen (bijvoorbeeld angst, depressie, ADHD, autisme en opvoedingsondersteuning).

Onderstaand wordt nader uitgewerkt welke adviezen gegeven kunnen worden ter preventie van emotionele, gedrags- en sociale problemen.

\subsubsection{Adviezen ter preventie van emotionele problemen}

Bij het voorkomen en verminderen van emotionele problemen bij kinderen en jeugdigen maken de meeste interventies gebruik van cognitieve gedragstherapie (Van Rooijen \& Ince, 2013;

Bienvenu \& Ginsburg, 2007; Ginsburg, 2004; Horowitz \& Garber, 2006; Meijer, Smit, Schoemaker \& Cuijpers, 2006; Barrett \& Turner, 2004; Merry, Hetrick, Cox, Brudevold-Iversen, Bir \& McDowell, 2011; Mychailyszyn e.a., 2012). De adviezen die de JGZ geeft aan ouders en kind kunnen gestoeld worden op deze aanpak. In de aanpak van cognitieve gedragstherapie worden irrationele cognities 
uitgedaagd en leren jeugdigen vanuit een ander perspectief naar dezelfde situatie te kijken en op een andere manier te reageren.

Angstige kinderen kunnen gebaat zijn bij geleidelijke blootstelling aan angstige situaties, gecombineerd met ontspanningstechnieken. Bij stemmingsproblemen zoals depressie staat de aanpak van negatieve gedachten of denkfouten centraal (Barrett \& Turner, 2004). Voor adviezen rondom angst en depressie kunnen de desbetreffende JGZ richtlijnen geraadpleegd worden.

\section{Ouders/gezin}

Ouders kunnen voorlichting krijgen over de ontwikkeling van hun kind en over 'normale' angsten tijdens de kindertijd en strategieën aanleren om het angstige of sombere gedrag van hun kind om te buigen. Enkele kenmerken van effectieve ouderprogramma's zijn (Ginsburg, 2004; Rapee, 2002):

- Voorlichting over de ontwikkeling van het kind, over normale angsten tijdens de kindertijd en over de ontwikkeling van problematische angst;

- Het belonen van dapper gedrag en het aanleren van strategieën om angstig gedrag te verminderen (bijvoorbeeld geleidelijke blootstelling aan angstige situaties);

- Demonstreren van dapper gedrag door de ouder in een angstige situatie, zodat het kind dit gewenste gedrag kan nadoen als reactie op de eigen angst;

- Het verbeteren van de communicatie binnen het gezin.

Kind

In interventies voor jeugdigen leren jongeren bijvoorbeeld vaardigheden om irrationele gedachten te herkennen en aan te passen. Daarnaast leren jongeren vaak probleemoplossende vaardigheden (bijv. omgaan met conflicten) en sociale vaardigheden (zoals een praatje maken, onderhandelen en leren werken in een groep).

\subsubsection{Adviezen ter preventie van gedragsproblemen}

Bij het voorkomen en verminderen van gedragsproblemen maken de meeste interventies gebruik van (cognitieve) gedragstherapie (Foolen et al, 2013). De adviezen die de JGZ geeft aan ouders en kind kunnen gestoeld worden op deze aanpak. In de aanpak van cognitieve gedragstherapie wordt positieve feedback gegeven op het positieve gedrag van jeugdigen. Ongewenst gedrag wordt zoveel mogelijk genegeerd. Hierdoor neemt het positieve gedrag van jeugdigen vaak toe, en het ongewenste gedrag af. Gedragstherapie wordt vaak in twee vormen ingezet. De ene vorm is oudertraining. De ouders leren vaardigheden om de gedragstherapie thuis toe te passen. Een andere vorm is gedragstherapie in groepsvorm voor jeugdigen met een gedragsprobleem.

\section{Ouders}

Ouders kunnen vaardigheden aanleren om positief gedrag te stimuleren en negatief gedrag te verminderen. Dit staat centraal bij preventieve opvoedingsondersteuning (Foolen et al., 2013) Voor advisering hieromtrent wordt ook verwezen naar de JGZ-richtlijn Opvoedingsondersteuning (Oudhof, de Wolff, de Ruiter, Kamphuis, L'Hoir, \& Prinsen, 2013) . Een vorm van preventieve opvoedondersteuning zijn groepsgerichte ouderprogramma's, waarin ouders opvoedingsvoorlichting krijgen, opvoedvaardigheden aanleren en informatie uitwisselen met andere ouders. Enkele kenmerken van effectieve ouderprogramma's zijn (Watson, White, Taplin, \& Huntsman, 2005; Bunting, 2004; Moran e.a. 2004; Kaminski e.a. 2008; in: Ince, 2013):

- Ouders leren om het gedrag dat veranderd moet worden te identificeren en te monitoren; 
- Goed gedrag wordt bekrachtigd en negatief gedrag genegeerd of er worden consequenties aan verbonden; Concrete voorbeelden van vaardigheden om positief gedrag te stimuleren (afkomstig uit interventies als Opvoeden en zo en Triple P) zijn: tijd en aandacht geven, praten met kinderen, complimenten geven, en het goede voorbeeld geven. Concrete voorbeelden van vaardigheden om ongewenst gedrag te kunnen hanteren zijn: basisregels afspreken, heldere instructies geven, en consequent reageren als regels worden overschreden zoals het toepassen van 'stil zitten' of 'time-out' (Janssen, Blokland, \& Ligtermoet, 2006; Sanders 2012).

- Het zelfvertrouwen van ouders wordt vergroot; ouders worden ondersteund bij het bedenken van manieren om hun eigen problemen op te lossen (Barrett, 2010; Watson e.a. 2005; Watson \& Tully, 2008).

- $\quad$ Het sociale netwerk van ouders wordt versterkt (Webster-Stratton, 1997; Walker \& Riley 2001).

\section{Kind}

In interventies voor jeugdigen leren jongeren bijvoorbeeld vaardigheden waardoor zij constructiever om kunnen gaan met hun boosheid. In trainingen die gericht zijn op het verminderen van gedragsproblemen worden vaak irrationele gedachten ('ik ben waardeloos', 'ze moeten altijd mij hebben') aangepakt. Jongeren leren vanuit een ander perspectief naar dezelfde situatie te kijken en leren dat ze ook op een andere manier kunnen reageren. Daarnaast leren jongeren vaak probleemoplossende en sociale vaardigheden (leren omgaan met conflicten, omgaan met groepsdruk, 'nee zeggen') (Foolen \& van der Steege, 2013).

\subsubsection{Adviezen ter preventie van sociale problemen}

In de voorgaande paragrafen zijn ook sociale problemen voor een groot deel al aan bod gekomen. Zo is bijvoorbeeld ingegaan op de vraag hoe positief en/of sociaal gedrag bevorderd kan worden. Ook is onder 'emotionele problemen' ingegaan op preventieprogramma's die gericht zijn op het aanleren van sociale vaardigheden. Een specifieke vorm van sociale problemen die nog niet aan bod is gekomen, is pesten.

Er zijn veel anti-pestprogramma's ontwikkeld, waarbij het merendeel wordt uitgevoerd binnen scholen. De beste resultaten worden vooralsnog behaald met een schoolbrede aanpak. In deze aanpak worden interventies op schoolniveau, klassikaal niveau en individueel niveau gecombineerd (Wurf, 2012; in: van Rooijen, Udo, Wienke, \& Daamen, 2015). Zie voor meer informatie ook de JGZ richtlijn Pesten .

\subsection{Effectieve interventies bij psychosociale problemen}

De derde en laatste uitgangsvraag luidt: "Wat zijn (bewezen effectieve) interventies die de JGZ-professionals kunnen toepassen bij psychosociale problemen?". Het gaat dan om interventies voor psychosociale problemen, die aan twee criteria moeten voldoen:

1. Het zijn in Nederland beschikbare interventies, die kunnen worden ingezet om psychosociale problemen - meer in het bijzonder emotionele, gedrags- of sociale problemen - te verminderen of om de risico's op deze psychosociale problemen te verminderen.

2. Het zijn interventies, die kunnen worden toegepast door de professionals van JGZ-organisaties voor ouders en jeugdigen uitgaande van de kerntaken van de JGZ: 
signaleert en geeft voorlichting, advies, instructie en begeleiding (VWS, 2014). Hiermee kan de eigen kracht van kinderen, jongeren en ouders worden versterkt en (indien mogelijk) kunnen ervaren problemen worden genormaliseerd. Preventie en lichte ondersteuning kunnen zwaardere hulp mogelijk voorkomen. Het aanbod van de interventies is afhankelijk van de lokale situatie. Conform de Jeugdwet en de Wet Publieke Gezondheid moet de gemeente dit zorgaanbod afstemmen op de zorgbehoeften van jeugdigen en ouders en op de gezondheidssituatie van de jeugd in de eigen gemeentelijke regio.

\subsubsection{Beschikbare interventies bij psychosociale problemen}

In deze paragraaf is in Tabel 1 het overzicht opgenomen van de thans in Nederland beschikbare interventies bij preventie van psychosociale problemen. Die interventies zijn in onderstaande tabel uitgesplitst naar de drie problematieken (emotionele problemen, gedragsproblemen en sociale problemen). In de tabel wordt aangegeven voor welke leeftijd van het kind de interventie geschikt is en het niveau van preventie waarop ze kunnen worden ingezet: universeel of geïndiceerd.

De complete uitwerking van alle interventieprogramma's op alle preventieniveaus vindt $u$ op de $\mathrm{NJI}$ website databank effectieve jeugdinterventies in

(http://www.nji.nl/nl/Databank/Databank-Effectieve-Jeugdinterventies) .

Om de in Nederland beschikbare interventies te identificeren hebben we geput uit de Databank Effectieve Jeugdinterventies van het Nederlands Jeugdinstituut [LINK

www.nji.nl/jeugdinterventies]. In die databank zijn de effectieve jeugdinterventies opgenomen, die zijn beschreven en in Nederland ingezet kunnen worden . Het gaat hierbij om een brede groep van jeugdinterventies die ingezet kunnen worden binnen de jeugdgezondheidszorg (preventie en gezondheidsbevordering) en binnen de jeugdhulpverlening, onderwijs gerelateerde interventies en interventies ten behoeve van het jeugdwelzijn. Een interventie komt in aanmerking voor opname in de databank als de interventie in theorie effectief is, dat wil zeggen: de interventie is goed beschreven en theoretisch goed onderbouwd. Een onafhankelijke commissie doet op basis van Nederlands onderzoek een uitspraak over de effectiviteit van een interventie en publiceert dit op de website van het Nederlands Jeugdinstituut.

De Erkenningscommissie Interventies beoordeelt de effectiviteit van interventies op een uniforme manier en kan een erkenning afgeven in een van vier opeenvolgende categorieën:

- Goed onderbouwd: Een interventie krijgt deze classificatie als deze op z'n minst goed beschreven is en als aannemelijk is gemaakt dat met die interventie het gestelde doel kan worden bereikt.

- Effectief volgens eerste aanwijzingen: Een interventie is effectief volgens eerste aanwijzingen als uit onderzoek met zwakke of indicatieve bewijskracht, bijvoorbeeld veranderingsonderzoek, blijkt dat er voldoende effect optreedt bij uitvoering van de interventie, ook al staat nog niet vast dat dit effect (helemaal) door de interventie wordt veroorzaakt.

- Effectief volgens goede aanwijzingen: Een interventie is effectief volgens goede aanwijzingen als uit onderzoek met beperkte bewijskracht blijkt dat bepaalde doelen er in de praktijk beter mee worden bereikt dan met andere interventies of met niets doen.

- Effectief volgens sterke aanwijzingen: Een interventie is effectief volgens sterke aanwijzingen als uit voldoende onderzoek met sterke of zeer sterke bewijskracht blijkt dat 
bepaalde doelen er in de praktijk beter mee worden bereikt dan met andere interventies of met niets doen. 
Tabel 1. Psychosociale problemen gekoppeld aan leeftijd en mogelijk in te zetten interventies (bron: NJI databank effectieve jeugdinterventies).

(http://www.nji.nl/nl/Databank/Databank-Effectieve-Jeugdinterventies) - (1-7-2016)

\begin{tabular}{|c|c|c|c|}
\hline Emotionele problemen & Leeftijd & Effectiviteit $^{1}$ & $\begin{array}{l}\text { Universeel/ } \\
\text { geïndiceerd }^{2}\end{array}$ \\
\hline Brussencursus & 9-17 jaar & 4 & Universeel \\
\hline Dappere Dino's & 6-9 jaar & 4 & Universeel \\
\hline D(o)epressiecursus & 16-21 jaar & 4 & Geïndiceerd \\
\hline Dyslexie de Baas! & 12-17 jaar & 4 & Geïndiceerd \\
\hline Gripopjedip online & 16-25 jaar & 4 & Geïndiceerd \\
\hline Happyles & 13-25 jaar & 4 & Universeel \\
\hline Head Up & 13-17 jaar & 4 & Geïndiceerd \\
\hline Jes! Het Brugproject & 8-12 jaar & 4 & Universeel \\
\hline Je bibbers de baas & 9-12 jaar & 4 & Geïndiceerd \\
\hline KIES & 8-18 jaar & 4 & Universeel \\
\hline KopOpOuders & 1-18 jaar & 4 & Universeel \\
\hline Kopstoring & 16-26 jaar & 4 & Universeel \\
\hline My identity & 13-19 jaar & 4 & Universeel \\
\hline Move2Learn & $12-18$ jaar & 4 & Geïndiceerd \\
\hline M@ZL & 12-21 jaar & 4 & Universeel \\
\hline NIKA & $0-6$ jaar & 4 & Universeel \\
\hline Opvoeden \& Zo & 4-12 jaar & 4 & Universeel \\
\hline Op Koers & 8-18 jaar & 4 & Universeel \\
\hline Ouderschap Blijft & $0-12$ jaar & 4 & Universeel \\
\hline Ouder-baby-interventie & $0-4$ jaar & 2 & Geïndiceerd \\
\hline Pedagogisch adviseren & 0-19 jaar & 4 & Universeel \\
\hline Shantala babymassage & Baby (0-1 jr) & 4 & Universeel \\
\hline Stoere schildpadden & 4-7 jaar & 4 & Universeel \\
\hline Storm en Spetters & 4-7 jaar & 4 & Universeel \\
\hline SurvivalKid & 12-24 jaar & 4 & Universeel \\
\hline Triple P & 0-16 jaar & 4 & Universeel \\
\hline VRIENDEN & 8-17 jaar & 4 & Universeel \\
\hline Zippy's Vrienden & 5-8 jaar & 4 & Universeel \\
\hline Gedragsproblemen & Leeftijd & Effectiviteit $^{1}$ & $\begin{array}{l}\text { Universeel/ } \\
\text { geïndiceerd }^{2}\end{array}$ \\
\hline Agressieregulatie op maat Ambulant 16- & 12-16 jaar & 4 & Geïndiceerd \\
\hline Alles Kidzzz & 9-12 jaar & 2 & Geïndiceerd \\
\hline Basic Trust & 2-6 jaar & 4 & Geïndiceerd \\
\hline Dappere Dino's & $6-9$ jaar & 4 & Universeel \\
\hline Directieve thuisbehandeling & 12-18 jaar & 4 & Geïndiceerd \\
\hline Gordon-training "Effectief communiceren met kinderen." & 1-18 jaar & 4 & Universeel \\
\hline Home-Start & $0-6$ jaar & 4 & Universeel \\
\hline Incredible Years (basic) & 3-7 jaar & 1 & Geïndiceerd \\
\hline $\begin{array}{l}\text { Kortdurende Video-hometraining (K-VHT) in gezinnen met jonge } \\
\text { kinderen }\end{array}$ & $0-4$ jaar & 4 & Universeel \\
\hline Multidimensionele familietherapie (MDFT) & 12-19 jaar & 1 & Geïndiceerd \\
\hline Opvoeden \& Zo & 4-12 jaar & 4 & Universeel \\
\hline OUDERS van tegendraadse jeugd; themabijeenkomsten & $8-16$ jaar & 4 & Universeel \\
\hline OUDERS van tegendraadse jeugd; Opvoedworkshops & 8-16 jaar & 4 & Geïndiceerd \\
\hline
\end{tabular}




\begin{tabular}{|c|c|c|c|}
\hline Ouders Voorop! & & & \\
\hline OUDERS van tegendraadse jeugd; Oudercursus. & 8-16 jaar & 4 & Geïndiceerd \\
\hline OUDERS van tegendraadse jeugd; Ouders van een jeugdgroep. & 8-16 jaar & 4 & Geïndiceerd \\
\hline M@zl & 12-21 jaar & 4 & Universeel \\
\hline Move2Learn & 12-18 jaar & 4 & Geïndiceerd \\
\hline Parent Management Training Oregon (PMTO) & 4-12 jaar & 3 & Geïndiceerd \\
\hline Pedagogisch adviseren & 0-19 jaar & 4 & Universeel \\
\hline Praten met Kinderen & 10-15 jaar & 2 & Universeel \\
\hline SPRINT (Signalering en Preventieve Interventie bij antisociaal gedrag) & 8-13 jaar & 4 & Geïndiceerd \\
\hline Stevig Ouderschap (6 huisbezoeken door JGZ-verpleegkundige) & $0-18 \mathrm{mnd}$ & 4 & Geïndiceerd \\
\hline Stoere schildpadden & 4-6 jaar & 4 & Universeel \\
\hline Taakspel & 7-13 jaar & 1 & Universeel \\
\hline Treatment Foster Care Oregon-Adolescenten (TFCO-A) & $12-18$ jaar & 4 & Geïndiceerd \\
\hline Triple P & $0-16$ jaar & 4 & Universeel \\
\hline $\begin{array}{l}\text { Video-hometraining (VHT) in gezinnen met kinderen in de } \\
\text { basisschoolleeftijd }\end{array}$ & 4-13 jaar & 4 & Universeel \\
\hline $\begin{array}{l}\text { Video-feedback Intervention to Promote Positive Parenting and Sensitive } \\
\text { Discipline (VIPP-SD) }\end{array}$ & 1-4 jaar & 1 & Geïndiceerd \\
\hline VoorZorg & $-9 \mathrm{mnd}-2 \mathrm{jr}$ & 2 & Geïndiceerd \\
\hline Sociale problemen & Leeftijd & Effectiviteit $^{1}$ & $\begin{array}{l}\text { Universeel/ } \\
\text { geïndiceerd }^{2}\end{array}$ \\
\hline Begrijp me goed & 14-18 jaar & 4 & Universeel \\
\hline Bewust actief leren (BAL) & 12-18 jaar & 4 & Geïndiceerd \\
\hline Boys R Us & 10-15 jaar & 4 & Universeel \\
\hline Competentietraining 6-12 jarigen Het $A B C$ & 6-12 jaar & 4 & Geïndiceerd \\
\hline De vreedzame school & 4-13 jaar & 3 & Universeel \\
\hline Gay-Straight Alliances op scholen & 12-19 jaar & 4 & Universeel \\
\hline Gelijk = Gelijk? & 10-13 jaar & 4 & Universeel \\
\hline Gedrag: ik doe ertoe! & $12-16$ jaar & 4 & Universeel \\
\hline Girls' Choice & 10-16 jaar & 4 & Universeel \\
\hline Girls' Talk & 14-18 jaar & 4 & Universeel \\
\hline Juf, doet u ook aan seks? & 4-12 jaar & 4 & Universeel \\
\hline It's up to you & 12-15 jaar & 4 & Universeel \\
\hline Kanjertraining & 4-15 jaar & 1 & Universeel \\
\hline KiVa & 7-13 jaar & 2 & Universeel \\
\hline Lang leve de Liefde - onderbouw & 13-15 jaar & 2 & Universeel \\
\hline Lang leve de Liefde - bovenbouw & 15-19 jaar & 4 & Universeel \\
\hline Leefstijl & 4-19 jaar & 4 & Universeel \\
\hline Leskatern Relaties \& Seksualiteit & 4-12 jaar & 4 & Universeel \\
\hline Let's Talk & 12-19 jaar & 4 & Universeel \\
\hline LoveNSex & 12-26 jaar & 4 & Universeel \\
\hline Opgroeien met liefde & $0-18$ jaar & 4 & Universeel \\
\hline Plezier op school & 11-13 jaar & 3 & Geïndiceerd \\
\hline PRIMA & 4-13 jaar & 4 & Universeel \\
\hline Programma Alternatieve Denkstrategieën (PAD) & 4-12 jaar & 2 & Universeel \\
\hline School-Wide Positive Behavior Support (SWPBS) & 5-19 jaar & 4 & Universeel \\
\hline SchoolsOUT & 4-21 jaar & 4 & Universeel \\
\hline Sta Sterk Training & 8-12 jaar & 4 & Geïndiceerd \\
\hline Tweede Wereldoorlog in Perspectief & 12-17 jaar & 4 & Universeel \\
\hline
\end{tabular}

1. 1= Effectief volgens sterke aanwijzingen, 2= Effectief volgens goede aanwijzingen, $3=$ Effectief volgens eerste aanwijzingen, $4=$ Goed onderbouwd. 
Op basis van de Databank Effectieve Jeugdinterventies hebben we een actueel overzicht samengesteld (zie Tabel 1) van de programma's en interventies voor psychosociale problemen die momenteel uitgevoerd zouden kunnen worden binnen de jeugdgezondheidszorg. Het kan ook zijn dat de jeugdgezondheidszorg de toeleiding naar deze programma's verzorgt. De interventies en programma's worden ingezet op verschillende (preventie-) niveaus binnen de jeugdgezondheidszorg:

- universele (preventieve) interventieprogramma's voor alle kinderen en ouders;

- selectieve (preventieve) interventieprogramma's voor groepen met risicofactoren;

- en ten slotte ook het aanbod van interventieprogramma's voor ouders en jeugdigen op indicatie. Bij die laatste groep interventies en programma's hebben we als selectiecriterium gehanteerd dat het aanbod via de JGZ ingezet wordt. Programma's en interventies die uitsluitend in de gespecialiseerde jeugdhulp of justitiële instellingen worden ingezet, hebben we achterwege gelaten.

Zelf zoeken naar geschikte interventies in de Databank Effectieve Jeugdinterventies kan via de uitgebreide zoekfunctie (via www.nji.nl/jeugdinterventies). In deze zoekfunctie kan onder andere gezocht worden op onderwerp (bijvoorbeeld angst, sociale vaardigheden, pesten, weerbaarheid), niveau van effectiviteit, leeftijd, doel (preventie, behandeling, ondersteuning) en uitvoeringslocatie (thuis, op school, in een zorginstelling). Ook kunnen selecties gemaakt worden: zo kunt u bijvoorbeeld bekijken welke erkende preventieve interventies er zijn voor kinderen van 4-12 jaar met goede aanwijzingen voor effectiviteit; of welke erkende interventies beschikbaar zijn voor kinderen van ouders met psychische of verslavingsproblemen (KOPP-kinderen); of welke erkende interventies inspelen op het vergroten van sociale vaardigheden op school. Allerlei selecties zijn mogelijk.

Alle interventies die in de Databank zijn opgenomen worden na vijf jaar opnieuw beoordeeld op actualiteit en vooruitgang. Ook een aantal van de in Tabel 1 opgenomen interventies bevindt zich op dit moment in de herbeoordelingsprocedure. Hierdoor is het mogelijk dat niet bij elke interventiebeschrijving in de bijlage het meest recente onderzoek is opgenomen. Het overzicht is gebaseerd op de informatie die op 1 juli 2016 via de Databank beschikbaar is.

Er zijn in Nederland meer interventies beschikbaar dan de interventies die op dit moment in de Databank Effectieve Jeugdinterventies zijn opgenomen. Er zijn interventies in aanvraag, in ontwikkeling (b.v. CJG4kracht) of ze verkeren in een experimenteel stadium. Die interventies zijn nu niet in Tabel 1 (en niet in de NJI databank) opgenomen met als belangrijkste overwegingen, dat er nog geen of onvoldoende zicht op de kwaliteit is en ze niet zonder meer overdraagbaar en implementeerbaar zijn.

Er bestaan grofweg twee typen interventies om psychosociale problemen aan te pakken:

- interventies gericht op de omgeving van jeugdigen;

- $\quad$ en interventies gericht op de jeugdigen zelf.

Sommige interventies bieden een combinatie van bovenstaande benaderingen, doordat zij gericht zijn op zowel het kind, als de ouder en/of de leerkracht. Een uitgebreide beschrijving van de beschikbare interventies is te vinden via de Databank Effectieve Jeugdinterventies (www.nji.nl/jeugdinterventies). 
Aansluitend op de taken volgens de Wet Publieke Gezondheid en de taken die gemeenten aan de JGZ toekennen vanuit de jeugdwet en de Wmo is een keuze te maken voor de inzet van deze beschikbare interventies. Uiteraard moet en mag daarbij ook altijd het criterium gewogen worden in hoeverre de JGZ - dan wel haar beroepsbeoefenaren - over de competenties en expertise beschikken om ze uit te voeren. Dat heeft onder meer te maken met het gegeven of organisaties wel of niet de deskundigheid van (ortho)pedagogen en/of psychologen in huis hebben. De taxatie is, dat JGZ-organisaties daarin verschillen al naar gelang de gemeentelijke taakstelling en beschikbare expertise en capaciteit. Aangeraden wordt om, bij het ontbreken van de deskundigheid om een bepaalde interventie uit te voeren, de samenwerking op te zoeken met instanties die deze deskundigheid wel hebben. Een belangrijke voorwaarde om de zorg rondom psychosociale problemen te kunnen uitvoeren, is dat JGZ medewerkers goed op de hoogte zijn van het lokale aanbod en mogelijkheden en participeren in de diverse ketens.

\section{Referenties}

Barrett, P.M. \& Turner, C.M. (2004). Prevention of Childhood Anxiety and Depression. In P.M. Barrett \& T.H. Ollendick. Interventions that work with children and adolescents. Prevention and Treatment, pp. 429-474.

Barrett, H. (2010). The delivery of parent skills training programmes. Meta-analytic studies and systematic reviews of what works best. London: Family and Parenting Institute.

Bartelink, C., Berge, I. ten \& Yperen, T. van (2013). Beslissen over hulp. Utrecht: Nederlands Jeugdinstituut (NJi).

Bartelink, C. (2013a). Wat werkt: oplossingsgerichte therapie? Utrecht: Nederlands Jeugdinstituut (NJi).

Bartelink, C. (2013b). Wat werkt: motiverende gespreksvoering? Utrecht: Nederlands Jeugdinstituut ( $\mathrm{NJi})$.

Bienvenu, O.J. \& Ginsburg, G.S. (2007). Prevention of anxiety disorders. International Review of Psychiatry, 19 (6), 647-654.

Bunting, L. (2004). Parenting Programmes: The best Available Evidence. Child Care in Practice. Vol. 10, No. 4, October 2004, pp. 327-343.

Daamen, W. \& Ince, D. (2014). Wat werkt bij het bevorderen van een positieve ontwikkeling van jeugdigen? Utrecht: Nederlands Jeugdinstituut (NJi).

Foolen, N., Ince, D., Baat, M. de \& Daamen, W. (2013). Wat werkt bij gedragsproblemen en gedragsstoornissen? Utrecht: Nederlands Jeugdinstituut (NJi).

Foolen, N. \& Steege, M. van der (2013). Van dwars gedrag tot gedragsstoornis. Blauwdruk voor een preventie- en zorgarrangement. Utrecht: Nederlands Jeugdinstituut ( $\mathrm{NJi}$ ).

Gemmeke, M. (2011). De rol van de Centra voor Jeugd en Gezin bij versterking van de pedagogische civil society. Utrecht: Nederlands Jeugdinstituut (NJi).

Ginsburg, G.S. (2004). Anxiety prevention programs for youth: practical and theoretical considerations. Clinical Psychology: Science and Practice, 11: 430-434.

Heerwaarden van Y. \& Pijpers, F. De kracht van zelfregie. Samen komen tot passende hulp en ondersteuning. NCJ, Utrecht, 2015.

Horowitz, J.L. \& Garber, J. (2006). The prevention of depressive symptoms in children and adolescents: a meta-analytic review. Journal of Consulting and Clinical Psychology, 74(3), 401-415.

Ince, D. (2013). Wat werkt in opvoedingsondersteuning? Utrecht: Nederlands Jeugdinstituut (NJi).

Ince, D., Yperen, T. van \& Valkestijn, M. (2013). Top tien positieve ontwikkeling jeugd. Beschermende factoren in opvoeden en opgroeien. Utrecht: Nederlands Jeugdinstituut (NJi). 
Janssen, H., Blokland, G. \& Ligtermoet, I. (2006). Opvoeden \& Zo. Draaiboek voor een oudercursus. Utrecht, NIZW Jeugd.

Kaminski Wyatt, J., Valle, L.A., Filene, J.H., \& Boyle, C.L. (2008). A Meta-analytic Review of Components Associated with Parent Training Program Effectiveness. Journal of Abnormal Child Psychology, 36, 567-589.

Meijer, S.A., Smit, G., Schoemaker, C.G. \& Cuijpers, P. (2006). Gezond verstand. Evidence-based preventie van psychische stoornissen. Bilthoven: RIVM.

Merry, S.N., Hetrick, S.E., Cox, G.R., Brudevold-Iversen, T, Bir, J.J. \& McDowell, H. (2011). Psychological and educational interventions for preventing depression in children and adolescents (Review). The Cochrane Collaboration

Moran, P., Ghate, D., \& van der Merwe, A. (2004). What works in parenting support? A review of the international evidence. London: Department for Education and Skills. Journal of Abnormal Child Psychology, 34, 527-542.

Mychailyszyn, M., Brodman, D., Read, K. \& Kendall, P. (2012). Cognitive-behavioral school-based interventions for anxious and depressed youth: a meta-analysis of outcomes. Clinical Psychology: Science and Practice, 19, 129-153. 


\section{Thema 4 Samenwerking}

\section{Inleiding}

De JGZ maakt sinds januari 2015 deel uit van het nieuwe jeugdstelsel waardoor de focus nog meer komt te liggen op preventie, ondersteuning en lichte zorg, dichtbij in de leefomgeving van het kind en het gezin. De JGZ werkt hierbij samen met ouders/jongeren zelf en zal waar mogelijk het sociale netwerk van het gezin erbij betrekken.

Kenmerkend voor de JGZ professional is zijn integrale visie, dat wil zeggen: de JGZ professional kijkt niet alleen naar lichamelijke, psychische en sociale aspecten van het kind, maar ook naar het sociale en fysieke leefmilieu van het kind. In deze integrale werkwijze, werkt de JGZ professional altijd samen met andere professionals die betrokken zijn bij het kind en/of zijn leefomgeving, bijvoorbeeld de curatieve gezondheidszorg, de jeugdhulpverlening, het onderwijs en wijk- en buurtteams.

\section{Aanbevelingen}

- Als JGZ professional werk je in de eerste plaats samen met ouders en jeugdigen. Werk volgens de NCJ handreiking 'De kracht van zelfregie'.

- Neem als JGZ professional het initiatief om de samenwerking met partners (o.a. school; voorschoolse voorzieningen, geboortezorg professionals, huisarts, het sociale wijkteam, de jeugd GGZ, jeugdhulp, CJG en VeiligThuis) beter te laten verlopen.

De JGZ professional zet zich in voor:

- Persoonlijke kennismaking: zorg voor bekendheid met elkaar en elkaars werk en werkgebied. Plan een kennismakingsgesprek; persoonlijk contact en vertrouwen helpt om in gemeenschappelijke casussen samen te werken.

- Direct contact: zorg voor goede bereikbaarheid door per werkgebied rechtstreekse telefoonnummers of digitale middelen (zoals mailadressen, ouderportalen, app groepen) beschikbaar te hebben.

- Concrete afspraken: maak duidelijke afspraken over doorverwijzen, terugkoppeling, gegevensuitwisseling en bereikbaarheid. Leg deze afspraken schriftelijk vast.

- Onderhoud van de contacten: bespreek één of twee keer per jaar met elkaar hoe de samenwerking verloopt en wat de resultaten zijn. Gezamenlijke bijeenkomsten en/of (na)scholingen dragen bij aan een verdere kennismaking. 
- Ten aanzien van de samenwerking met school en de voorschoolse voorziening geldt aanvullend:

- Zorg dat je als JGZ professional deelneemt aan de zorgstructuur van school en van de voorschoolse voorziening.

- Het raadplegen van school of de voorschoolse voorziening door de JGZ (of visa versa) gebeurt in overleg, en na toestemming van de ouders en zo mogelijk in aanwezigheid van de ouders. De partij die signaleert of een vermoeden heeft van een psychosociaal probleem neemt het initiatief om toestemming aan de ouders te vragen.

- Bij twijfel over een psychosociaal probleem bij 0-4 jarigen: onderbouw het vermoeden met aanvullende informatie via pedagogisch medewerker, (ortho)pedagoog van de kinderopvang of peuterspeelzaal, of van een ander betrokken zorgverlener bij het kind en/of gezin.

- Bij twijfel over een psychosociaal probleem bij 4-18 jarigen: onderbouw het vermoeden met aanvullende informatie via de leerkracht van het kind (4-12 jarige) of mentor (12-18 jaar).

- Bij een complex psychosociaal probleem, of een probleem dat al langere tijd blijft voortbestaan: neem contact op met de zorgstructuur van de voorschoolse voorziening (0-4 jaar), het primair onderwijs (4-12 jaar) of zorgcoördinator van het zorgteam in het voortgezet onderwijs (12-18 jaar).

- $\quad$ Ten aanzien van de meldcode Kindermishandeling geldt: (zie ook JGZ richtlijn

Kindermishandeling)

- Bij een vermoeden van huiselijk geweld (waaronder partnergeweld) of kindermishandeling werk je volgens de Meldcode kindermishandeling. Een onderdeel van de Meldcode is dat je contact opneemt met VeiligThuis voor advies.

- Zorg dat je als JGZ professional in beeld bent bij de professionals die te maken hebben met de Kindcheck (onderdeel van de Meldcode), zoals (huis)artsen, verpleegkundigen, maatschappelijk werkers, psychiaters en psychologen.

- Ten aanzien van samenwerking met de huisarts geldt aanvullend dat de JGZ professional rechtstreeks contact opneemt met de huisarts in de volgende situaties:

- Bij verwijzing naar een medische professional zoals jeugd GGZ, jeugdhulp, maatschappelijk werk of andere hulp zoals schulphulpverlening (alleen jeugdarts of verpleegkundig specialist);

- Bij (vermoedens van) kindermishandeling in een gezin of bij een jeugdige (zie JGZ richtlijn kindermishandeling).

- Indien ouders/jeugdige nooit verschijnen dan wel weigeren deel te nemen aan JGZ-programma en er aanleiding is voor (een vermoeden van) zorgen over de veiligheid van het kind.

- Wees bekend met regels rondom gegevensuitwisseling in samenwerkingsverbanden.

\section{Uitgangsvraag}


- Welke samenwerkingsafspraken moet de JGZ met welke partijen maken over de signalering van psychosociale problemen?

\section{Onderbouwing}

\subsection{Samenwerken rond de signalering}

Van een JGZ professional wordt verwacht dat hij/zij psychosociale problemen tijdig signaleert, het gezin lichte ondersteuning en advisering aanbiedt; en specialistische zorg betrekt of een gezin verwijst naar specialistische zorg als de problematiek te complex is. Deze aspecten worden vanuit het perspectief van de samenwerking toegelicht.

De eerste personen met wie de JGZ professional van doen heeft zijn de ouders en de jeugdigen zelf.

\subsubsection{Samenwerken met ouders en jeugdigen}

Het toeleiden naar zorg is een gezamenlijk proces van professional samen met de ouder(s) en/of de jeugdige. Dit proces start met het bespreken van vragen, wensen of zorgen met ouders en jeugdigen, waarna met elkaar wordt verkend wat er nodig is om de gezondheidssituatie te verbeteren. Belangrijke uitgangspunten staan beschreven in de NCJ handreiking 'kracht van de zelfregie' (van Heerwaarden \& Pijpers, 2015) . Deze uitgangspunten zijn:

- Jeugdigen en ouders zijn de experts van hun eigen leven. De JGZ-professional sluit aan bij de aanwezige behoefte en werkt vanuit gelijkwaardig partnerschap aan het bevorderen van ontwikkeling en gezondheid. De JGZ-professional werkt vanuit de vraag: welk doel willen jeugdigen en ouders bereiken en wat hebben zij daarvoor nodig? Wat kunnen zij zelf, waar kan het eigen sociale netwerk hen bij ondersteunen? De JGZ-professionals werkt vanuit gelijkwaardig partnerschap aan het bevorderen van ontwikkeling en gezondheid.

- Versterking van het functioneren en participeren van de jeugdigen. De JGZ-professional zoekt samen met ouders en jeugdige een aanpak die het functioneren van de jeugdige zo goed mogelijk versterkt. Vanuit een biopsychosociale blik kijkt de JGZ-professional naar aanwezige vragen, zorgen, ervaren last, gedeelde doelen, talenten en mogelijkheden van jeugdigen en ouders zelf.

- Gezamenlijke en gelijkwaardige besluitvorming. Beslissingen worden gezamenlijk en in gelijkwaardigheid genomen. Het proces van besluitvorming is gericht op het informeren en het vergroten van de controle van de betrokkenen over besluiten die hun gezondheid en welbevinden aangaan. De volgende 6 stappen leiden tot gezamenlijk besluitvorming 1) Wederzijds informatie uit wisselen (wat is er al geprobeerd? Welke mogelijkheden zijn er volgens de professional?)

2) Bedenktijd inlassen

3) Vragen of ze willen meebeslissen

4 ) Gezamenlijk een beslissing nemen

5) Gezamenlijk een plan opstellen en

6) Vervolgafspraken maken.

Als meerdere hulpverleners betrokken zijn bij de jeugdige en het gezin, dan dient deze hulp gecoördineerd te worden. Als ouders zelf in staat zijn te sturen op afstemming en uitvoering van alle hulp en zorg, dan heeft dat de voorkeur en hoeft er geen zorgcoördinator aangewezen te 
worden. Als ouders zelf niet in staat zijn zo'n rol te vervullen dan moet vanuit een instantie de zorgcoördinator geleverd worden. Dit gebeurt van uit de principes van één gezin, één plan (Blom, 2013).

Het kan voorkomen dat de JGZ professional een signaal opvangt met betrekking tot de psychosociale ontwikkeling van het kind of de opvoed- en opgroeisituatie van een kind. Dan is het nodig om de zorgen met de ouders te delen, op een professionele wijze waarbij de ouders zich serieus genomen voelen en zonder dat er onnodig geproblematiseerd wordt. Dat vraagt specifieke competenties van de professional die verder toegelicht worden in de JGZ richtlijn

Opvoedingsondersteuning (Oudhof et al., 2013) .

\subsubsection{Samenwerken met andere professionals}

De JGZ werkt samen met andere professionals die betrokken zijn bij het kind en/of zijn leefomgeving, bijvoorbeeld de curatieve gezondheidszorg, de jeugdhulpverlening en het onderwijs.

In de NCJ Factsheet Samenwerking Huisartsen en de JGZ (NCJ, 2016) wordt kernachtig omschreven hoe een goede samenwerking bevorderd kan worden. Deze kernpunten zijn niet alleen van belang bij de samenwerking met de huisarts, maar met alle mogelijke partners (school; voorschoolse voorzieningen, geboortezorg professionals, huisarts, het sociale wijkteam, de jeugd GGZ, jeugdhulp, CJG en VeiligThuis).

$\mathrm{Er}$ is sprake van een goede samenwerking wanneer aan de volgende vier voorwaarden voldaan is:

- Persoonlijke kennismaking: de JGZ professional voert een kennismakingsgesprek en onderhoudt persoonlijk contact met de andere professionals;

- Direct contact: de JGZ professional zorgt voor goede bereikbaarheid door per werkgebied rechtstreekse telefoonnummers of digitale middelen (zoals mailadressen, ouderportalen, app groepen) beschikbaar te hebben;

- Concrete afspraken: de JGZ professional maakt duidelijke afspraken over doorverwijzen, terugkoppeling, gegevensuitwisseling en bereikbaarheid;

- Onderhoud van de contacten: de JGZ professional bespreekt één of twee keer per jaar met elkaar hoe de samenwerking verloopt en wat de resultaten zijn. Gezamenlijke bijeenkomsten en/of (na)scholingen dragen bij aan een verdere kennismaking.

\subsubsection{Geboortezorg professionals}

Bij kinderen die nog niet bij de JGZ in beeld zijn, is de JGZ-professional aangewezen op de geboortezorg professionals (verloskundige, gynaecoloog en kraamverzorgende) om problemen te signaleren. Voor een goede samenwerking is het nodig dat deze geboortezorg professionals de JGZ weten te vinden wanneer er tijdens de zwangerschap zorgen ontstaan over de opgroei-omstandigheden voor het kind. Het is belangrijk dat de JGZ investeert in de samenwerking met geboortezorg professionals, bijvoorbeeld door ervoor te zorgen dat de geboortezorgprofessionals in het werkgebied weten hoe zij de JGZ kunnen bereiken, en dat helder is hoe gegevensuitwisseling plaatsvindt.

Geboortezorgprofessionals kunnen bij de aanpak van risicogroepen gebruik maken van het aanbod van de JGZ, zoals prenatale huisbezoeken of programma's zoals Voorzorg en Stevig Ouderschap. Dit aanbod verschilt per werkgebied.

\subsubsection{De huisarts}

De huisarts biedt laagdrempelige, generalistische zorg en fungeert als een eerste aanspreekpunt voor mensen met vragen of problemen over gezondheid en ziekte. Verder beheert de huisarts de medische gegevens van het gezin. Dit maakt dat de huisarts een belangrijke partner is voor JGZ 
professionals, wanneer zij psychosociale problemen constateren of vermoeden, en aanvullende gegevens nodig hebben. Randvoorwaarden voor een goede samenwerking zijn dat de huisartsen in het werkgebied de JGZ professionals kunnen bereiken, en dat er afspraken zijn gemaakt over verwijzing, terugkoppeling, gegevensuitwisseling en zorgcoördinatie (LESA, 2010; Rutte, Pijpers \& Timmermans, 2013; NCJ, 2008; 2016).

In bepaalde situaties is het van belang dat de JGZ professional rechtstreeks contact opneemt met huisartsen:

- $\quad$ Bij verwijzing naar een medische professional zoals jeugd ggz, jeugdhulp, maatschappelijk werk of andere hulp zoals schulphulpverlening ;

- $\quad$ Bij (vermoedens van) kindermishandeling in een gezin of bij een jeugdige (Zie verder JGZ Richtlijn Kindermishandeling (Vink et al., 2016) ;

- $\quad$ Indien ouders/jeugdige nooit verschijnen dan wel weigeren deel te nemen aan JGZ-programma en er is aanleiding voor (een vermoeden van) zorgen over de veiligheid van het kind.

\subsubsection{School en voorschoolse voorzieningen}

Wanneer een JGZ professional een vermoeden heeft van een psychosociaal probleem en dit vermoeden moet verder onderzocht worden, dan is de school en voorschoolse voorzieningen (zoals de kinderopvang of de peuterspeelzaal) in de regel de eerst aangewezen partij om navraag te doen. Omgekeerd kan het ook zo zijn dat juist de leerkracht een psychosociaal probleem signaleert, en hierom contact opneemt met de JGZ professional. Het is belangrijk dat de JGZ afspraken maakt met school en de voorschoolse voorziening(en) over afstemming rondom deze kinderen. In een aantal gemeentes bestaan ook al voorschoolse zorgteams.

\section{Kinderopvang en peuterspeelzaal}

Voor kinderen jonger dan 4 jaar zijn professionals van de kinderopvang of de peuterspeelzaal een belangrijke bron van informatie voor de JGZ-professional. Bij twijfels of een kind een psychosociaal probleem heeft kan aanvullende informatie ingewonnen worden bij de pedagogisch medewerker of (ortho)pedagoog van de kinderopvang of peuterspeelzaal. Het inwinnen van informatie dient altijd plaats te vinden in overleg met de ouders. Over het algemeen is de sociaal-emotionele ontwikkeling van het hele jonge kind nog sterk gekoppeld aan de cognitieve en motorische ontwikkeling van het kind. Een kind dat niet goed in zijn vel zit, en psychosociale problemen heeft uit dat op jonge leeftijd veelal op meerdere domeinen.

\section{Primair onderwijs}

Voor kinderen ouder dan 4 jaar is de school een belangrijke bron van informatie voor de JGZ professional met betrekking tot psychosociale problemen. De leerkracht maakt het kind in verschillende situaties gedurende een langere tijd mee (in de klas, in de omgang met leeftijdgenoten) en kan het kind en diens gedrag vergelijken met leeftijdgenoten. Bij twijfels over de aanwezigheid van een psychosociaal probleem kan de leerkracht of een begeleidingsteam geraadpleegd worden over het functioneren van het kind op school.

Ouders dienen in alle omstandigheden betrokken te zijn bij ieder overleg over hun kind. Het raadplegen van school of de voorschoolse voorziening zal daarom altijd in overleg, en na toestemming en zo mogelijk in aanwezigheid van de ouders plaatsvinden. De regel hierbij is dat de partij die signaleert of een vermoeden heeft van een psychosociaal probleem, het initiatief neemt om de ouders te informeren.

De zorgstructuur op school speelt een belangrijke rol in de signalering en aanpak van psychosociale problemen. Om die reden is het wenselijk dat een JGZ professional zitting heeft in 
deze zorgstructuur. Dit geldt ook voor scholen voor speciaal onderwijs. De zorgstructuur in het primair onderwijs bestaat uit directeur, IB-er, onderwijsspecialist (meestal een orthopedagoog) en een gezinsspecialist (jeugdarts, jeugdverpleegkundige, verpleegkundig specialist, schoolmaatschappelijk werker, en de betrokken ouders. Andere professionals (zoals een GZ psycholoog) kunnen op uitnodiging deelnemen aan het overleg. Vanuit de zorgstructuur kan ook de link gelegd worden met het sociale wijkteam en/of het bovenschoolse team ( Zorg en Adviesteam).

\section{Voortgezet Onderwijs}

Wanneer een JGZ-professional een vermoeden heeft van een psychosociaal probleem (enkelvoudige problematiek) bij een adolescent, dan kan hij/zij contact opnemen met de mentor/docent van de leerling. Bij meer complexe problematiek (bijvoorbeeld rond schoolverzuim, problemen met middelengebruik) dan is het raadzaam dat de JGZ-professional de deskundigheid van een zorgteam inschakelt via de zorgcoördinator van de school van de leerling. In een zorgteam kunnen de volgende disciplines een plaats hebben: de JGZ professional, een zorgcoördinator, een orthopedagoog/psycholoog, een vertegenwoordiger van Jeugdhulp, en de leerplichtambtenaar en op afroep politie en verslavingszorg. De deelnemers van het zorgteam zijn gezamenlijk verantwoordelijkheid voor de gang van zaken en uitvoering van functies in het team. Meestal fungeert de zorgcoördinator van de school als voorzitter. Voor de JGZ is het van belang om contact te hebben met de zorgcoördinatoren van de scholen in het werkgebied. Middels deze persoon kan het zorgteam ingeschakeld worden bij complexe problemen.

\subsubsection{Sociale wijkteam}

Sinds 1 januari 2015 zijn er 'sociale wijkteams' (ook wel 'wijkteam', 'jeugdteam' 'jeugd en gezinsteam' 'basisteam' of 'toegangsteam' genaamd) in de gemeenten. Hoewel dit per gemeente verschilt en nog erg in ontwikkeling is, bestaat een sociaal wijkteam in de regel uit beroepskrachten van verschillende organisaties, die allen als generalist werken volgens het principe van 'één gezin, één plan: coördinatie van zorg'. Het sociale wijkteam gaat uit van de eigen kracht van de wijkbewoners en hun sociale netwerk. De hulpvraag en de specifieke behoefte van de jeugdige en het gezin staan centraal in het wijkteam, om de hulp zoveel mogelijk op maat te kunnen bieden. Hierbij wordt uitgegaan van de sterke punten van een gezin. Bij voorkeur wordt er één hulpverlener ingezet bij een gezin. Deze hulpverlener heeft kennis van meerdere domeinen rond het gezin (opvoeding, huisvesting, arbeid enz.) en biedt waar mogelijk zelf hulp. Voor kennis die hij niet heeft vraagt hij advies bij een collega. Het gezin heeft de regie over de hulp. De sociale wijkteams zijn in Nederland heel divers georganiseerd en de JGZ maakt niet altijd deel uit van deze teams. Gezien de preventieve en signalerende taak van de JGZ is een goede aansluiting wenselijk. Wanneer de JGZ geen deel uitmaakt van het sociale wijkteam, dan is het belangrijk dat de JGZ-instelling contact legt met de sociale wijkteams in het werkgebied en ervoor zorgt dat de wijkteams weten hoe zij de JGZ kunnen bereiken. Ook is het nodig dat de JGZ-instelling in deze situatie samenwerkingsafspraken met de sociale wijkteams in de regio maakt over de wijze waarop JGZ advies vraagt, hoe onderling verwezen wordt, hoe teruggekoppeld wordt naar elkaar, en hoe gegevensuitwisseling plaatsvindt.

\subsection{Samenwerking rond de ondersteuning van gezinnen}

De meerwaarde van lichte hulp en opvoedingsondersteuning door de JGZ professional is dat de bekende vertrouwde JGZ-professionals deze lichte hulp aanbieden. Er is geen verwijzing of kennismaking nodig. Er kan worden voortgeborduurd op de reeds opgebouwde vertrouwensband tussen JGZ-professional en ouder/kind. We kunnen hierbij denken aan programma's als Triple $P$ 
(niveau 3 en 4), Stevig Ouderschap, Video Interactie Begeleiding, Kortdurende Video Hometraining, of de VIPP-SD en de Kanjertraining (zie Thema 3). Deze interventies kunnen door gemeenten bij de JGZ ingekocht worden, maar zijn niet beschikbaar voor alle ouders en kinderen. In die gevallen waar de problematiek ernstiger is en/of de juiste expertise bij de JGZ ontbreekt, is het nodig om extra hulp in te schakelen en het gezin door te geleiden naar adequate hulp. Voor een goede doorgeleiding is het nodig dat de JGZ in teamverband gebruik kan maken van specialistische kennis als dat nodig is. Het is daarom belangrijk dat de JGZ-professional goed op de hoogte is van de sociale kaart. Tevens is het belangrijk dat de JGZ professional bewust is van zijn/haar eigen grenzen, zodat gezinnen met complexe problematiek niet te lang onder eigen beheer gehouden worden.

Hieronder bespreken we de belangrijkste samenwerkingspartners als het gaat om verwijzen naar meer specialistische hulp.

\subsubsection{Jeugdhulp en Jeugdbescherming}

Om te komen tot een goed functionerende zorg voor jeugd is het nodig dat de JGZ gebruik kan maken van specialistische kennis bij een vermoeden van een psychosociaal probleem. Voor veel enkelvoudige problematiek kunnen de JGZ professionals binnen een CJG of de GGD zelf hulp indiceren, deze vervolgens bieden of eventueel hulp erbij halen. Voor zwaardere zorg en bij meerdere problemen (of onduidelijkheid van de aard of oorzaak van de problemen) kan een vorm van Jeugdhulp ingeroepen worden. Per 2015 zijn de voormalige Bureaus Jeugdzorg (BJZ) en de Jeugdzorgaanbieders als zodanig opgeheven en onder de regie van de gemeenten gekomen. 'Jeugdzorg' is nu onderdeel van de 'jeugdhulp'. De indicatiestelling voor jeugdhulp wordt door het sociale wijkteam, de jeugdarts/verpleegkundig specialist en de huisarts uitgevoerd. Andere taken van BJZ zoals jeugdreclassering en gezinsvoogdij zijn verder gegaan onder de noemer 'Jeugdbescherming'. In sommige regio's valt hieronder nog steeds de voormalige AMK-taak (nu Veilig Thuis).

\subsubsection{Veilig Thuis}

Veilig Thuis is de plaats waar een JGZ professional advies kan vragen zodra er vermoedens zijn van verwaarlozing of mishandeling over een kind (Zie ook de JGZ Richtlijn Kindermishandeling) . Zodra er een vermoeden ontstaat, is een JGZ professional verplicht de Meldcode Kindermishandeling en Huiselijk geweld te volgen. Concreet betekent dat de JGZ professional advies zal opvragen bij Veilig Thuis. Advies vragen is niet hetzelfde als het doen van een melding bij Veilig Thuis. Overleggen kan anoniem of met een geanonimiseerde casus. Veilig Thuis-medewerkers kunnen meedenken en tips geven en hebben kennis van signalen en risicofactoren en over juridische kwesties zoals omgaan met het beroepsgeheim. Indien er sprake is van acuut gevaar of een levensbedreigende situatie, moet altijd direct gemeld worden (zie meldcode in de JGZ-richtlijn kindermishandeling).

Veilig Thuis heeft de bevoegdheid om zonder toestemming van de betrokkene(n) persoonsgegevens te verwerken voor zo ver dit nodig is voor de uitoefening van haar wettelijke taken (maar dit geldt niet voor adviesvragen).

\section{Kindcheck}

De kindcheck is onderdeel van de Wet meldcode huiselijk geweld en kindermishandeling. Doel van de kindcheck is om meer kinderen in beeld te krijgen die ernstig risico lopen mishandeld of verwaarloosd te worden. De kindcheck is speciaal bedoeld voor mensen die werken met volwassen cliënten, zoals (huis)artsen, verpleegkundigen, maatschappelijk werkers, psychiaters en 
psychologen. De kindcheck houdt in dat de professional in contacten met volwassen cliënten nagaat of er kinderen in het gezin zijn en inschat of zij veilig zijn. Men doet dit bijvoorbeeld bij volwassen cliënten met ernstige psychische problemen of drugs- of alcoholverslaving. Of bij cliënten die een partner hebben die geweld gebruikt.

Zijn er twijfels over de veiligheid van de kinderen? Dan worden de stappen van de meldcode doorlopen. Eerst wordt vastgelegd welke signalen bij de ouder aanleiding geven tot twijfel over de veiligheid van de kinderen. Daarna worden de verdere stappen van de meldcode doorlopen die ervoor zorgen dat er ook verder onderzoek plaatsvindt en dat er, zo nodig, passende hulp komt (Zie JGZ Richtlijn Kindermishandeling) .

De kindcheck dient niet alleen uitgevoerd te worden door de JGZ, maar ook andere professionals kunnen een beroep doen op de JGZ wanneer er twijfels zijn over de veiligheid van een kind. Het is belangrijk dat de deze professionals weten dat zij de JGZ kunnen raadplegen.

\subsubsection{Jeugd-GGZ}

De Jeugd-GGZ (Geestelijke Gezondheidszorg) diagnosticeert en biedt hulp aan kinderen en jongeren van 0 tot 18 jaar, met psychiatrische of psychosociale klachten die zodanig zijn dat zij daardoor in hun ontwikkeling worden bedreigd. Dit kan intramuraal of ambulant zijn of via een vrijgevestigde psycholoog of -psychiater, (ortho)pedagoog - als basis- of gespecialiseerde Jeugd-GGZ.

De beoordeling van de psychische gesteldheid van jeugdigen moet uitgevoerd worden door een (GGZ-) deskundige. Toeleiding naar de Jeugd-GGZ valt onder verantwoordelijkheid van de gemeente, op lokaal niveau zijn hierover afspraken gemaakt. De jeugdarts of verpleegkundig specialist (en huisarts) kunnen direct verwijzen naar de Jeugd-GGZ (Jeugdwet, 2015).

\subsubsection{Andere professionals}

Ten slotte dient de JGZ te investeren in de samenwerking met de volgende instellingen.

- Algemeen Maatschappelijk Werk (schuldhulpverlening, relatieproblemen, huisvestingsproblemen, werk en inkomen);

- Volwassenen GGZ en psychiatrie, waaronder verslavingszorg;

- Maatschappelijke Opvang/Vrouwenopvang (Blijf van m'n Lijf);

- Paramedici zoals logopediste, fysiotherapeut etc;

- Medisch Specialisten.

Samenwerking kost tijd: men moeten rekenen op een ontwikkelingstijd van tien tot vijftien jaar om te komen tot succesvolle samenwerkingsverbanden (Ten Berge et al., 2012). Dat vraagt om structurele lange termijn investering in de onderlinge relaties. Dit kan echter op gespannen voet staan met de werkvloer waar op korte termijn gehandeld en besloten moet worden. Daardoor kan de gewoonte ontstaan om autonoom handelen. Besteed daarom blijvend aandacht aan de samenwerking, zowel op bestuurlijk, managementniveau als tussen individuele professionals.

\subsection{Gegevensuitwisseling in samenwerkingsverbanden - privacywetgeving}

Het uitwisselen van medische gegevens in samenwerkingsverbanden voor zorgprofessionals wordt bepaald door regels uit het gezondheidsrecht. In overlegsituaties bijvoorbeeld in sociale wijkteams is het vaak nodig dat er gegevens over patiënten en cliënten uitgewisseld worden. Een zorgprofessional met een beroepsgeheim (zwijgplicht) mag zijn geheimhoudingsplicht doorbreken met toestemming van de patiënt. Voor zorgverleners die rechtstreeks bij de directe behandeling van de patiënt zijn betrokken geldt dat geen toestemming is vereist. Wel geldt de eis dat alleen die 
informatie verstrekt mag worden die noodzakelijk is om de vereiste taken uit te kunnen voeren. Overige legitieme redenen om het beroepsgeheim te mogen doorbreken zijn: een wettelijke verplichting (denk aan melding dwangbehandeling) of conflict van plichten (zorgprofessional kan ernstige schade aan de patiënt of aan een ander voorkomen door informatie aan een derde te verschaffen). Voor meer informatie: zie Wegwijzer beroepsgeheim in samenwerkingsverbanden (NVO, 2014) [Link

https://vng.nl/onderwerpenindex/jeugd/jeugdhulp/nieuws/privacy-in-de-jeugdwet-hoe-zit-dat].

\section{Referenties}

Actiz (2012). Laagdrempelig, vertrouwd en dichtbij. De JGZ in het nieuwe jeugdstelsel. Utrecht: Actiz.

Berge, I. ten, Addink, A., Baat, M. de, Bartelink, C., Rossum, J. van \& Vinke, A. (2012). Stoppen en helpen: Een adequaat antwoord op kindermishandeling. Utrecht: SWP.

Blom, P. (2013). Handleiding Gezinsplan 1Gezin1Plan Zuid-Holland Noord. Versie 2013. (www.cjgprof.nl)

Heerwaarden, van Y., \& Pijpers F. (2015). De kracht van zelfregie. Samen komen tot passende hulp en ondersteuning. Utrecht: Nederlands Centrum Jeugdgezondheid (NCJ).

Inspectie voor de Gezonsheidszorg (2014). De jeugdgezondheidszorg beter in positie. Ministerie van Volksgezondheid, Welzijn en Sport. Utrecht.

Klein Ikkink, A. J., Boere-Boonekamp, M. M., Bont, M. D., Boer, A. D., Duys, H., Haasnoot, R., ... \& Westerveld, M. C. (2010). Landelijke Eerstelijns Samenwerkings Afspraak Kindermishandeling (LESA). Huisarts en Wetenschap, 53(8), S15-S20.

LESA (2010). Landelijke Eerstelijns Samenwerkings Afspraak (LESA) Kindermishandeling. Nederlands Huisartsen Genootschap, 2010.

NCJ (2008). Handreiking samenwerking Huisarts Jeugdgezondheidszorg. Utrecht: Nederlands Centrum Jeugdgezondheid (NCJ).

NCJ (2016). Factsheet Samenwerking Huisartsen en de JGZ, het beste van twee werelden. Factsheet NCJ, 10 februari 2016 (www.ncj.nl).

NVO (2014). Het beroepsgeheim in samenwerkingsverbanden. Een wegwijzer voor zorgprofessionals. December 2014. https://www.nvo.nl/

Oudhof, M., Wolff, M., de Ruiter, M., Kamphuis, M., L'Hoir, M., \& Prinsen, B. (2013). JGZ richtlijn opvoedingsondersteuning. Voor opvoedvragen en lichte opvoedproblemen. Utrecht: Nederlands Centrum Jeugdgezondheid (NCJ).

Rutte, F., Pijpers, F., \& Timmermans, M. ( 2013), Samenwerken aan het gezond en veilig laten opgroeien van kinderen. Een literatuurstudie. Utrecht: Nederlands Centrum Jeugdgezondheid (NCJ).

Timmermans, M., van Heerwaarden, Y. \& Pijpers, F. (2014). Samen = Beter. Inspiratie document om samen te werken in de zorg voor jeugd. Utrecht: Nederlands Centrum Jeugdgezondheid (NCJ).

Vink, R., de Wolff, M., Broerse, A., Heerdink, N., van Sleuwen, B., \& Kamphuis, M. (2016). JGZ Richtlijn kindermishandeling. Leiden/ Utrecht: TNO \& NCJ. 


\section{Totstandkoming richtlijn}

\section{Werkwijze}

In de eerste werkgroep vergadering zijn alle uitgangsvragen doorgenomen. Per uitgangsvraag is gekeken of deze samen kon gaan met een andere uitgangsvraag, welke in de inleiding beantwoord dienen te worden, welke artikelen en auteurs bij dat thema belangrijk zijn en welke vragen een evidence-based of practice-based benadering verdienen (of beide). Daarnaast is er ook inhoudelijk gesproken over de uitgangsvragen. Hiermee waren de uitgangsvragen definitief vastgesteld. De richtlijn is ontwikkeld volgens de methode van evidence-based richtlijnontwikkeling (EBRO) (CBO Kwaliteitsinstituut voor de Gezondheidszorg, 2007). De basis voor de richtlijn is een samenvatting van het beschikbare bewijs in de wetenschappelijke literatuur. Op basis hiervan zijn aanbevelingen geformuleerd voor de praktijk. De concept versies van de richtlijn zijn besproken tijdens de werkgroep bijeenkomsten in maart, april, juni 2015 en februari 2016. Tijdens deze bijeenkomsten werd de inhoud besproken en bediscussieerd. In juni 2015 is de conceptversie van de richtlijn voorgelegd aan de klankbordgroep. Het concept werd in september 2015 voorgelegd aan de Richtlijnadviescommissie (RAC) van het Centrum Jeugdgezondheid en ZonMw.

Landelijke commentaarronde en proefimplementatie

De richtlijn is gepubliceerd op websites ten behoeve van een landelijke open commentaarronde. Als onderdeel van de ontwikkeling is een proefimplementatie (pilot) uitgevoerd, waarbij de richtlijn in de JGZ-praktijk getest is. Deze pilot is bedoeld om inzicht te krijgen in problemen bij de uitvoering en de invoerstrategie die daar het beste bij past. Daarnaast is de pilot van belang om ook de richtlijn op tekst en inhoud aan te scherpen. Naar aanleiding van de landelijke commentaarronde en de proefimplementatie is de richtlijn nader aangepast. De aangepaste richtlijn is in mei 2016 voorgelegd aan de RAC van het Centrum Jeugdgezondheid.

Opstellen van BDS-protocol en indicatoren en autorisatie Naar aanleiding van de feedback van de RAC is de richtlijn aangepast en in september 2016 opnieuw voorgelegd aan de RAC ten behoeve van autorisatie. Ook is een BDS-protocol opgesteld waarin wordt aangegeven hoe handelingsaanbevelingen ten behoeve van de zorg voor het kind conform de meest actuele versie van Basisdataset JGZ op uniforme wijze kan worden geregistreerd. Tenslotte zijn er indicatoren opgesteld waarmee het gebruik van deze richtlijn op organisatieniveau en landelijk niveau inzichtelijk kan worden gemaakt.

\section{Werkgroep}

Bij de formatie van de werkgroep is gelet op een goede balans tussen wetenschappers, inhoudelijke experts en uitvoerende JGZ professionals. De werkgroep bestond uit 13 personen:

- $\quad$ Anneke Kesler, arts Maatschappij \& Gezondheid GGD Amsterdam (lid AJN)

- $\quad$ Regine van Riemsdijk, jeugdarts knmg GGD Hart voor Brabant (lid AJN)

- Ingrid Stellingwerf, Verpleegkundig Specialist Preventieve Somatische zorg Icare ( lid $\mathrm{V} \& \mathrm{VN})$

- $\quad$ Marja van Kuppevelt, verpleegkundig specialist, adviseur GGD Hart voor Brabant(lid $\mathrm{V} \& \mathrm{VN})$

- $\quad$ Magdie Boerwinkel, doktersassistente GGD ljsselland (Lid NVDA)

- Jeanneke Leferink, staf-/jeugdverpleegkundige Verian (vertegenwoordiger

JGZ-organisatie) 
- $\quad$ Drs. Swanet Woldhuis, directeur landelijke oudervereniging Balans

- $\quad$ Marieke Beentjes, orthopedagoog, (lid NVO)

- $\quad$ Prof. Dr. Frans Feron, Arts M\&G/jeugdarts en Hoogleraar Sociale Geneeskunde, in het bijzonder Jeugdgezondheidszorg, bij de vakgroep Sociale Geneeskunde van de Universiteit van Maastricht (voorzitter)

- $\quad$ Drs. Estelle Struis, psycholoog (lid NIP)

Vanuit TNO en NJI zijn daar de volgende mensen bij aangesloten

- $\quad$ Dr. Meinou Theunissen, onderzoeker TNO en inhoudsdeskundige.

- $\quad$ Dr. Marianne de Wolff; onderzoeker bij TNO, inhoudsdeskundige en richtlijndeskundige.

- $\quad$ Drs. Karen van Rooijen. Werkzaam bij NJI, expert databank effectieve jeugdinterventies.

\section{Klankbordgroep}

- $\quad$ Drs. Laura de Vries. Nederlandse Huisartsen Genootschap (NHG)

- $\quad$ Hans Jansen, (Nederlandse Vereniging voor Kindergeneeskunde)

- $\quad$ Dr. Matty Crone onderzoeker van het Leids Universitair Medisch Centrum (LUMC), afdeling Public Health en eerstelijnsgeneeskunde (PHEG)

- $\quad$ Prof. Dr. Menno Reijneveld hoogleraar sociale geneeskunde bij het Universitair Medisch Centrum Groningen, faculteit medische wetenschappen

- $\quad$ Drs. Bart Looman, Pharos, landelijk kennis- en adviescentrum op het gebied van diversiteit

- $\quad$ Nely Sieffers, afgevaardigde landelijke ouderraad. Moeder van twee zonen met autisme spectrum stoornis.

\section{Cliëntenparticipatie}

Bij de ontwikkeling van de richtlijn is rekening gehouden met het patiënten perspectief. Swanet Woldhuis (directeur van landelijke oudervereniging Balans) heeft een bijdrage geleverd aan de werkgroep. Nely Sieffers heeft een bijdrage geleverd in de klankbordgroep. Zij is afgevaardigde van de landelijke ouderraad en moeder van twee zonen met autisme spectrum stoornis. Een online focusgroep interview is gehouden met ouders en jongeren van 12 jaar of ouder. 


\section{Verantwoording}

\section{Zoekstrategie}

De uitgangsvragen waar een systematisch literatuursearch voor is uitgevoerd zijn samengevoegd in drie thema's: 1. Risico- en beschermende factoren, 2. Vroegsignalering 3. Advisering en effectieve interventies. Per thema staat hieronder beschreven op welke wijze de literatuur is verzameld.

\section{Thema 1: risico en beschermende factoren}

Uitgaande van de uitgangsvragen is door de projectgroep met hulp van de informatiespecialist van TNO, een systematisch literatuuronderzoek uitgevoerd betreffende risico- en beschermende factoren voor de ontwikkeling van psychosociale problemen in relevante databases: PubMed en PsychInfo. De volgende zoektermen werden onder andere gebruikt: risk factors, predictor, protective factors, screening, identification, internalizing, externalzing, psychosocial health, wellbeing. - problems, - dysfunction, affective symptoms, affective problems, behavioral problems, emotional problems.

De literatuursearch richtte zich op de periode 2008 tot 2015 en resulteerde in een lijst met 613 referenties: 377 artikelen binnen PsychInfo en 236 referenties van PubMed. Vervolgens hebben we de abstracts handmatig geselecteerd op relevantie, waarna 126 publicaties overbleven. Er zijn afzonderlijke searches gedaan naar prenatale risico- en beschermende factoren. Deze searches leverden aanvankelijk 257 publicaties op in PsychInfo en Pubmed. Na kritische lezing van deze abstracts bleven hiervan 54 artikelen over.

Studies die betrekking hebben op psychiatrische problematiek zoals ADHD of autisme, post-traumatische stress, drugs- of alcohol problematiek, suïcidaal gedrag, geweld, kindermishandeling, pesten, behandelingen en epilepsie werden buiten beschouwing gelaten. Daarnaast werd aan deze lijst m.b.v. de sneeuwbalmethode artikelen en aangedragen literatuur door werk- en klankbordgroepleden toegevoegd. De geselecteerde artikelen zijn beoordeeld op relevantie voor de uitgangsvraag en op hun methodologische kwaliteit volgens EBRO-methode. $\mathrm{Na}$ deze selectie bleven de artikelen over die als onderbouwing bij de verschillende conclusies in de richtlijn staan vermeld. De evidence is samengevat in 'evidentietabellen' (zie bijlage).

\section{Thema 2: vroegsignalering - instrumenten}

Uitgaande van de uitgangsvragen is door de projectgroep met hulp van de informatiespecialist van TNO, een systematisch literatuuronderzoek uitgevoerd betreffende gevalideerde vroegsignaleringsinstrumenten in Nederland voor de opsporing van psychosociale problemen bij kinderen in relevante databases: PubMed en PsychInfo. De literatuursearch richtte zich op de periode 2008 tot 2015, en de search was beperkt tot validatie onderzoek van signaleringsinstrumenten voor de opsporing van psychosociale problemen. Het onderzoek diende in Nederland uitgevoerd te zijn en de studie diende gebruik te hebben gemaakt van een community-based steekproef. De volgende zoektermen werden onder andere gebruikt: screening, identification, internalizing, externallzing, psychosocial health, - wellbeing. - problems, dysfunction, affective symptoms, affective problems, behavioral problems, emotional problems. De literatuursearch resulteerde in een lijst met 134 referenties: 80 artikelen binnen PsychInfo en 54 referenties van PubMed. De abstracts zijn handmatig geselecteerd op relevantie, waarna 13 publicaties overbleven. Deze search is aangevuld met de zogenaamde 'sneeuwbal methode'. Onder andere de resultaten van acht relevante proefschriften afkomstig uit Nederland zijn geanalyseerd (Hielkema, 2015; Kruizinga, 2015; Looij-Jansen, 2010; Mieloo, 2015; Theunissen, 
2013; Staal, 2016; Stone, Vogels, 2008). Instrumenten die bruikbaar zijn in de prenatale periode, zijn overgenomen van de JGZ richtlijn kindermishandeling (nog in ontwikkeling). De geselecteerde artikelen zijn beoordeeld op hun methodologische kwaliteit volgens EBRO-methode en als onderbouwing bij de verschillende conclusies in de richtlijn vermeld. De evidence is samengevat in 'evidentietabellen' (zie bijlage ).

\section{Thema 3: Advisering en effectieve interventies}

Bij de beantwoording van de vraag 'Wat kunnen JGZ-professionals doen bij psychosociale problemen als interventies ontbreken?' is gebruik gemaakt van recente overzichtsstudies, zoals de documenten in de Databank'Wat werkt', en programmeringsstudies, naastliggende richtlijnen, handreikingen en studies over algemeen werkzame elementen, competenties van professionals en beleidsonderzoek.

De uitgangsvraag 'Wat zijn collectieve en individuele preventieve adviezen aan ouders en de omgeving van het kind om de psychosociale ontwikkeling van het kind te stimuleren?' is beantwoord aan de hand van reviews in de zogenaamde 'Wat werkt'- Databank (o.a. Wat werkt bij angst- en stemmingsproblemen, Wat werkt bij opvoedingsondersteuning, Wat werkt bij gedragsproblemen en Wat werkt bij pesten) van het Nederlands Jeugdinstituut. JGZ richtlijnen? In deze documenten wordt een overzicht geboden van de laatste stand van zaken in wetenschappelijke literatuur rondom werkzame elementen. De overzichten zijn gebaseerd op systematische reviews en meta-analyses die zijn gevonden via searches in internationale wetenschappelijke databanken (o.a. Psyclnfo, ERIC, Cochrane en Campbell Collaboration).

Voor beantwoording van de uitgangsvraag 'Wat zijn (bewezen effectieve) interventies die de JGZ-professionals kunnen toepassen bij psychosociale problemen?' is gebruik gemaakt van de beschrijvingen van in Nederland beschikbare interventies ter preventie van psychosociale problemen, die zijn opgenomen in de Databank Effectieve Jeugdinterventies, op sommige punten aangevuld met gegevens uit een recent review. De interventies zijn in tabelvorm weergeven inclusief de onderbouwing van de NJI databank

- $\quad$ Goed onderbouwd: Een interventie krijgt deze classificatie als deze op z'n minst goed beschreven is en als aannemelijk is gemaakt dat met die interventie het gestelde doel kan worden bereikt.

- $\quad$ Effectief volgens eerste aanwijzingen: Een interventie is effectief volgens eerste aanwijzingen als uit onderzoek met zwakke of indicatieve bewijskracht, bijvoorbeeld veranderingsonderzoek, blijkt dat er voldoende effect optreedt bij uitvoering van de interventie, ook al staat nog niet vast dat dit effect (helemaal) door de interventie wordt veroorzaakt.

- $\quad$ Effectief volgens goede aanwijzingen: Een interventie is effectief volgens goede aanwijzingen als uit onderzoek met beperkte bewijskracht blijkt dat bepaalde doelen er in de praktijk beter mee worden bereikt dan met andere interventies of met niets doen.

- $\quad$ Effectief volgens sterke aanwijzingen: Een interventie is effectief volgens sterke aanwijzingen als uit voldoende onderzoek met sterke of zeer sterke bewijskracht blijkt dat bepaalde doelen er in de praktijk beter mee worden bereikt dan met andere interventies of met niets doen.

\section{Evidentietabellen en niveau van bewijsvoering}

Zie apart document 


\section{Overwegingen}

\section{Taken JGZ}

De vraag hoe de JGZ ouders, kinderen en jongeren maximaal kunnen ondersteunen, om gezond en veilig opvoeden en opgroeien mogelijk te maken staat centraal. De JGZ professional volgt de kinderen en kan zo de aanwezige risicofactoren wegen. Daarom wordt in het begin van de richtlijn (zie Taken JGZ) aandacht besteedt aan gezond opgroeien en opvoeden, en voorkomen van risico's en problemen. Ofwel bevorderen van positieve ontwikkeling.

\section{Thema 1: risico- en beschermende factoren}

Een opsomming van risicofactoren, die je in de praktijk kan afvinken is niet wenselijk. Het is belangrijk om te weten of er een evenwicht is tussen risico- en beschermende factoren. Daarbij is het nodig dat het kind in zijn omgeving gezien wordt.

\section{Thema 2: Vroegsignalering}

Er dient voorzichtig te worden omgegaan met het interpreteren van scores/ instrumenten die niet met de ouders zijn nabesproken. Het is belangrijk dat de duiding van het instrumenten in combinatie met een klinische observatie en in gesprek met de ouders/jeugdige plaatsvindt.

\section{Thema 3: Advisering en interventies}

Eén van de uitgangsvragen is: 'Wat kunnen JGZ-professionals doen bij psychosociale problemen als interventies ontbreken?' Als een bepaalde expertise niet aanwezig is bij de JGZ, dan dient de JGZ professional zorg te dragen voor een adequate verwijzing.

\section{Thema 4: samenwerking}

Als ouders psychiatrische problemen hebben, dan is het belangrijk om een gesprek te houden over de opvoeding. En van daaruit eventuele moeilijkheden of spanningen bespreekbaar te maken. In de samenwerking met ouders, worden problemen eerst besproken met de ouders, voordat informatie wordt ingewonnen bij andere hulpverleners van de ouder.

\section{Knelpuntenanalyse}

Zie apart document 